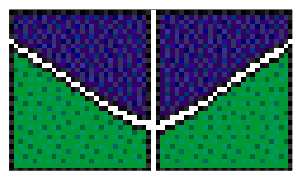

Universidade de Brasília

Instituto de Ciências Biológicas

Departamento de Botânica

Atividade fitotóxica de extratos e exsudatos radiculares de Guilandina bonduc (Fabaceae)

ALUNA: Graziela Luciana Petry

ORIENTADOR: Dra. Sarah Christina Caldas Oliveira

Brasília, DF 


\title{
Atividade fitotóxica de extratos e exsudatos radiculares de Guilandina bonduc (Fabaceae)
}

\author{
GRAZIELA LUCIANA PETRY \\ Orientador: Dra. Sarah Christina Caldas Oliveira
}

Dissertação apresentada ao Programa de Pós-graduação em Botânica da Universidade de Brasília, como parte dos requisitos para obtenção do título de Mestre em Botânica.

Brasília, DF 
A ciência nunca resolve um problema sem criar pelo menos outros dez". (George Bernard Shaw)

Dedico esse trabalho a: Aos meus pais por não medirem esforços para que eu chegasse até esta etapa da minha vida e pelo incentivo e apoio em todas as minhas escolhas 


\section{Agradecimentos}

Inicio meus agradecimentos por DEUS, já que Ele colocou pessoas tão especiais a meu lado, sem as quais certamente eu não teria dado conta.

Agradeço à minha orientadora Dra. Sarah Christina Caldas Oliveira, não só pela paciência, orientação e contribuição para o meu desenvolvimento profissional, mas pela confiança depositada e pela oportunidade dada a mim até mesmo antes de entrar para o mestrado. Agradeço também ao professor Dr. Fabian Borghetti que sempre se mostrou disposto a me auxiliar quando tive dúvidas.

A todos que passaram pelo laboratório, Prof. Flávia, Heide, Camila, Tito, Luísa, Natália, Glendo, Cinthya, que me fizeram companhia nessa caminhada e que de alguma forma vocês fazem parte dessa conquista.

As professoras Dra. Yris Maria Fonseca-Bazzo e Dra. Dâmaris Silveira por realizar e me auxiliar nas análises cromatográficas e ao professor Dr. Carlos Kleber Zago de Andrade pela realização das análises de RMN. Essas análises formam essenciais para a conclusão da dissertação.

Agradeço ao William por ter me ajudado a domar o HPLC, sem você eu não teria conseguido. Agradeço ao Paolo, pois sua ajuda foi fundamental para a conclusão do trabalho.

Aos amigos da Termobiologia e IB, Desirée, Leandro, Patricia, Hérica, Izabely, Estela, com os quais acabei passando mais tempo que com a minha própria família. Agradeço pelo convívio, pelas risadas, e momentos de descontração, por dividir as minhas preocupações e pelo apoio cientifico e emocional.

À D. Odete que é uma mãe e amiga, cuidando e se preocupando sempre, S. Manoel, S. Antônio e S. Francisco, S. Daniel, obrigada!

Aos meus amigos de Não Me Toque que me apoiaram nessa caminhada. A Juliélen que acabou de chegar em Brasília e me ajudou muito também. Ao Marcelo que mesmo conhecendo pouco tempo, me ajudou muito.

A família de Unaí que Deus me deu e me acolheu com todo o carinho do mundo e me deram apoio nessa caminhada, vocês são muito especiais pra $\operatorname{mim}$. 
Ao Bruno, meu Amor, amigo, companheiro, você fez com que as coisas se tornassem mais leves nos momentos mais difíceis, me ajudando sempre, me apoiando e me aguentando nos momentos de mau humor. Obrigada pela compreensão, pelos incentivos e por me fazer rir nos momentos mais difíceis e comemorar comigo cada conquista.

A Anabele minha amiga e a irmã que Deus me deu, por ter me acolhido, me incentivado e me encorajado, me ajudado em tudo, sem você eu não estaria aqui hoje.

A minha irmã Roberta e meu sobrinho Lucas, por simplesmente existir na minha vida, e do modo de vocês, acreditar em mim e me apoiar.

$E$ em especial aos meus pais por não medirem esforços para que eu estivesse aqui. Obrigada pelo seu apoio incondicional a longo deste processo de dissertação e de muitos outros. Obrigada por acreditarem em mim, mesmo quando eu não acreditava. Obrigada pelo amor, pelo carinho e afeto e por entenderem a minha ausência e distância. Vocês são minha fortaleza.

$\mathrm{E}$ a todos mais que eu não tenha citado aqui, mas que de uma forma ou de outra contribuíram não apenas para a minha dissertação, mas também para eu ser quem eu sou. 


\section{Sumário}

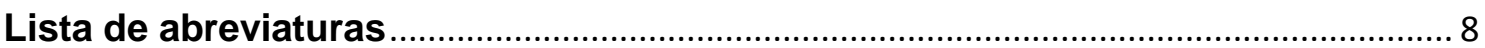

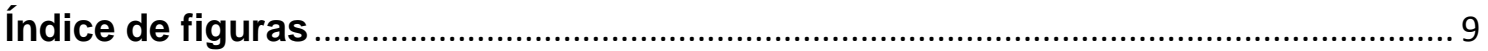

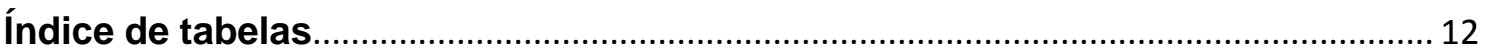

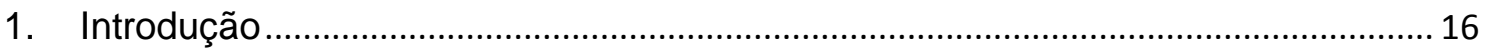

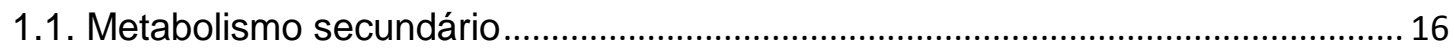

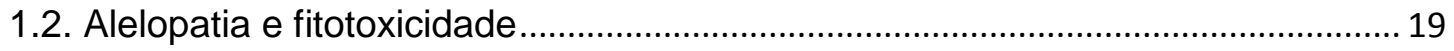

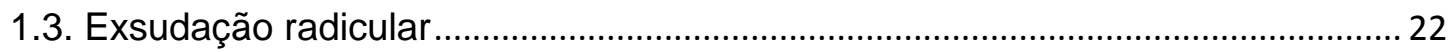

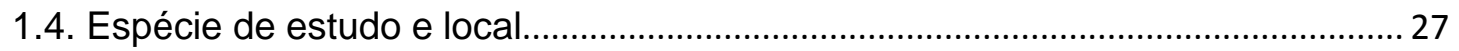

1.5. Métodos gerais para obtenção de agentes fitotóxicos de plantas .......................... 34

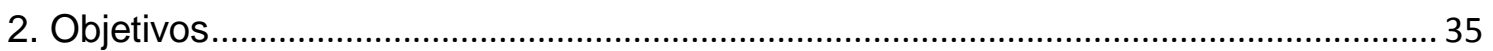

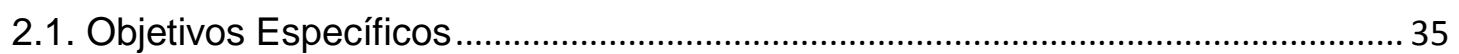

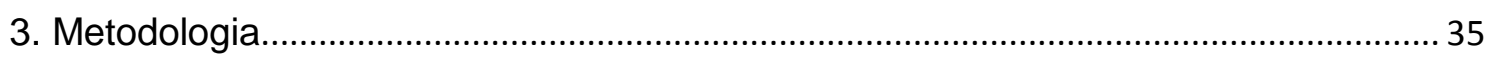

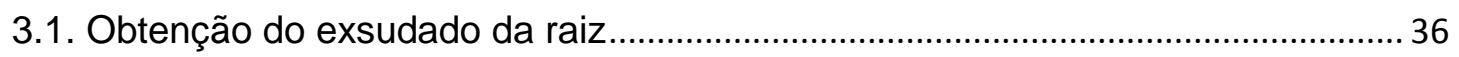

3.2. Estimativa da concentração dos exsudados liberados em campo ........................ 36

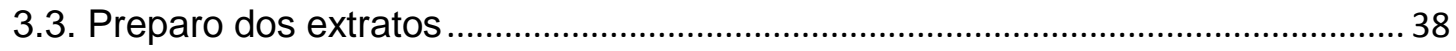

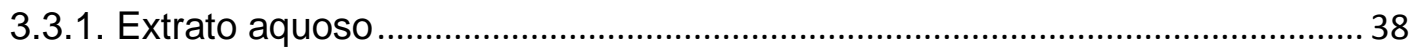

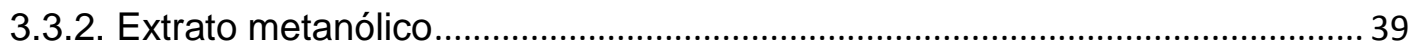

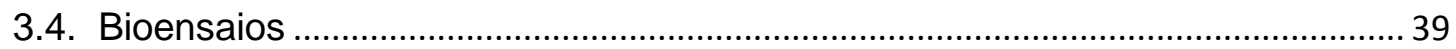

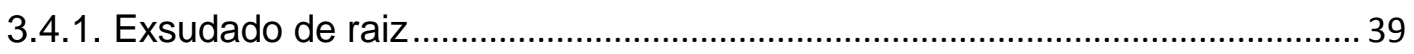

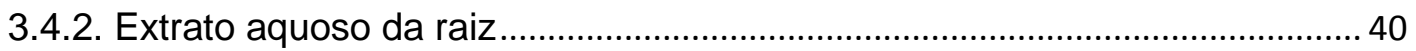

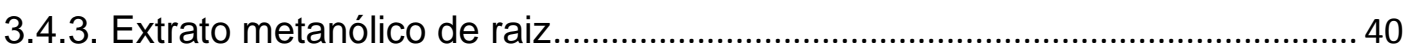

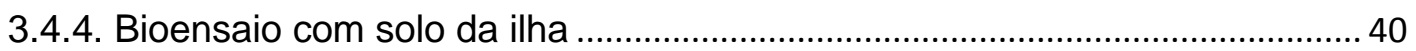

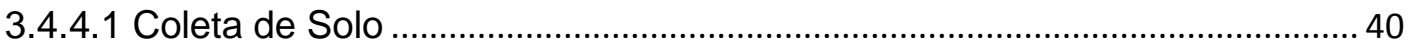

3.4.4.2 Bioensaio influência do extrato aquoso e microbiota do solo ....................... 41

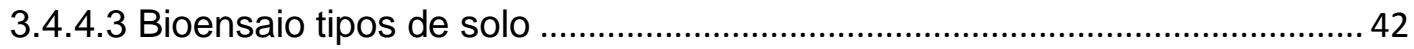

3.5. Isolamento e purificação das substâncias ................................................................ 43

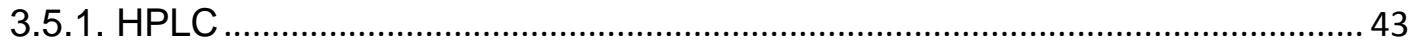

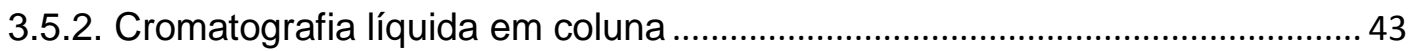

3.5.3 Identificação do produto por Ressonância Magnética Nuclear ........................ 44

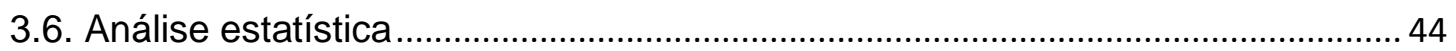

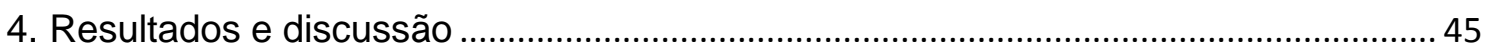

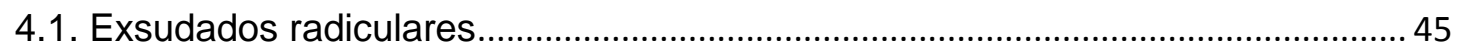

4.2 Estimativa de produção de exsudados radiculares em campo ................................4 47 


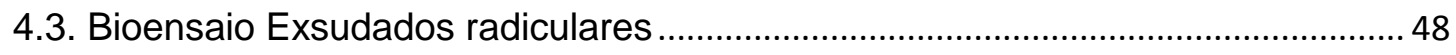

4.4. Bioensaio extrato aquoso de raiz ........................................................................ 51

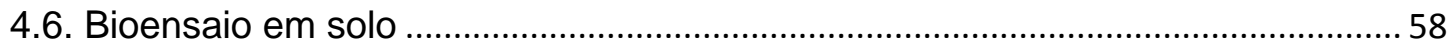

4.6.1 Efeito do extrato aquoso no crescimento das espécies alvo...........................58

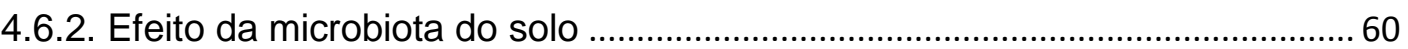

4.6.3. Efeito do tipo de solo nas espécies alvo...........................................................63 63

4.7. Comparação dos perfis cromatográficos dos extratos e exsudados radiculares 65

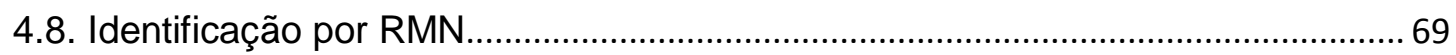

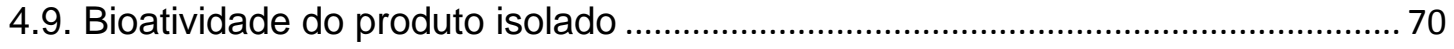

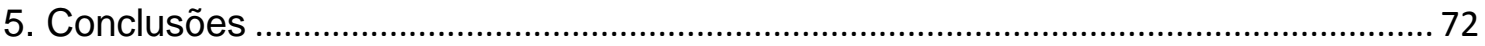

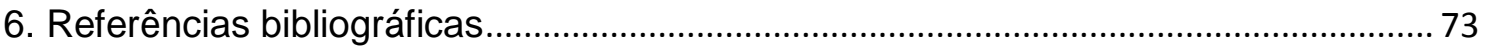

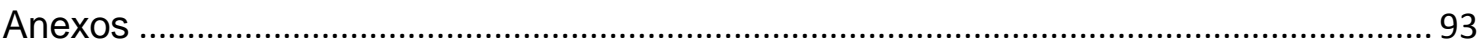




\section{Lista de abreviaturas}

CCD - Cromatografia em camada delgada

COSY - Homonuclear Correlation Spectroscopy

DEPT - Distortionless enhancement by polarization transfer

HMQC- Heteronuclear MultipleQuantum Coherence

HPLC - High-performance líquid chromatography

PA - Parte aérea

PR - Parte Radicular

RMN ${ }^{13} \mathbf{C}$ - Ressonância Magnética Nuclear de Carbono 13

RMN ${ }^{1} \mathbf{H}$ - Ressonância Magnética Nuclear de hidrogênio

RMN - Ressonância Magnética Nuclear

$\delta$ - Deslocamento químico 


\section{Índice de figuras}

Figura 1. Visão simplificada das principais rotas de biossíntese de metabólitos secundários e suas inter-relações com o metabolismo primário. (Fonte: Taiz \& Zeiger, 2009) 19

Figura 2. Modo de liberação dos metabólitos secundários pelas plantas. 21

Figura 3. Raízes de Guilandina bonduc chegando até as populações de Cyperus atlanticus 28

Figura 4. Perfil da llha da Trindade (Fonte: Bruno Rabelo) 32

Figura 5. Sistema de hidroponia com sistema de oxigenação constante para coleta dos exsudados radiculares de Guilandina bonduc. 36

Figura 6. Área de $1 \mathrm{~m}^{2}$ demarcada para obtenção da biomassa de Guilandina bonduc em população de ocorrência natural na llha de Trindade.

Figura 7. Pontos de coleta dos solos da llha de Trindade utilizados no bioensaio. Solo 1 - População de Guilandina bonduc; Solo 2- Solo descoberto; Solo 3 - População de Cyperus atlanticus.

Figura 8. Bandejas de células para crescimento das plântulas em bioensaio com solo 42

Figura 9. Correlação da produção de exsudados radiculares em relação a biomassa total da planta de Guilandina bonduc cultivadas em meio hidropônico durante 42 dias.

Figura 10. Porcentagem de inibição/estímulo no crescimento inicial da parte aérea (PA) e radicular (PR) das plântulas de alface (Lactuca sativa) (A) e plântulas de rabanete (Raphanus sativus) (B) influência dos exsudados radiculares de Guilandina bonduc. Letras diferentes indicam diferença estatística entre os tratamentos $e^{*}$ indica diferença estatística em relação ao controle. $p \leq 0,05$ 49 
Figura 11. Porcentagem de inibição/estímulo no crescimento inicial da parte aérea (PA) e radicular (PR) das plântulas de rabanete (Raphanus sativus) (A) e plântulas de alface (Lactuca sativa) ( $B$ sob influência de extrato aquoso radicular de Guilandina bonduc. Letras diferentes indicam diferença estatística entre os tratamentos $e^{*}$ indica diferença estatística em relação ao controle. $\mathrm{p} \leq 0,05$ 52

Figura 12. Porcentagem de inibição/estímulo no crescimento inicial da parte aérea (PA) e radicular ( $\mathrm{PR}$ ) das plântulas de rabanete (Raphanus sativus) (A) e plântulas de alface (Lactuca sativa) (B) sob influência de extrato metanólico radicular de Guilandina bonduc. Letras diferentes indicam diferença estatística entre os tratamentos $e^{*}$ indica diferença estatística em relação ao controle. $p \leq 0,05$ 55

Figura 13. Porcentagem de inibição/estímulo no crescimento inicial em relação ao controle, da parte aérea (PA) e radicular (PR) das plântulas de rabanete (Raphanus sativus) (A) e plântulas de alface (Lactuca sativa) (B), sob influência do extrato metanólico radicular de Guilandina bonduc. Letras diferentes indicam diferença estatística entre os tratamentos $e^{*}$ indica diferença estatística em relação ao controle. $p \leq 0,05$ 59

Figura 14. Média do comprimento da parte aérea (PA) e radicular (PR) de plântulas de rabanete (Raphanus sativus) ( $\mathrm{A}$ e B) e alface (Lactuca sativa) ( $\mathrm{C}$ e D) submetidas a diferentes concentrações do extrato aquoso radicular de Guilandina bonduc, utilizando solo como substrato com presença da microbiota (não autoclavado) e ausência de microbiota (Autoclavado). * indica diferença estatística em relação aos tratamentos. $p \leq 0,05$. 62

Figura 15. Média do comprimento da parte aérea (PA) e radicular (PR) de plântulas de rabanete (Raphanus sativus) (A) e alface (Lactuca sativa) (B) cultivadas em solo coletado em 3 diferentes pontos da ilha: abaixo da população de Guilandina bonduc itálico (1), solo na formação do halo desprovido de vegetação (2), abaixo da população de Cyperus atlanticus (3). Letras diferentes indicam diferença estatística entre os tratamentos. $p \leq 0,05$. . 64 
Figura 16. Perfis cromatográficos registrado em $280 \mathrm{~nm}$ de exsudado radicular (A), extrato aquoso (B) e extrato metanólico bruto (C) de raízes de Guilandina bonduc obtido a partir de HPLC. 66

Figura 17. Perfis cromatográficos registrado em $354 \mathrm{~nm}$ de exsudado radicular (A), extrato aquoso (B) e extrato metanólico bruto (C) de raízes de Guilandina bonduc obtido a partir de HPLC

Figura 18. Estrutura molecular de Caesaldekarin $C$ isolado a partir do fracionamento liquido-liquido e coluna cromatográfica do extrato metanólico da raiz de Guilandina bonduc L 69

Figura 19. Porcentagem de inibição/estímulo no crescimento inicial, da parte aérea (PA) e radicular (PR) das plântulas de rabanete (Raphanus sativus) ( $\mathrm{A}$ ) dias e plântulas de alface (Lactuca sativa) (B), sob influência de Caesaldekarin C isolado do extrato metanólico radicular de Guilandina bonduc. Letras diferentes indicam diferença estatística entre os tratamentos $e$ * indica diferença estatística em relação ao controle. $p \leq 0,05$. 


\section{Índice de tabelas}

Tabela 1. Substâncias isoladas de diferentes partes da planta de Guilandina bonduc $\mathrm{L}$. e a classe a qual pertence.

Tabela 2. Concentração dos exsudados radiculares de Guilandina bonduc liberados no período de 42 dias em meio hidropônico $(750 \mathrm{~mL})$, comprimento da parte aérea (PA) e radicular (PR) (em centímetros) e biomassa seca da parte aérea $(\mathrm{PA})$, radicular $(\mathrm{PR})$ e cotilédones das plantas cultivadas (em gramas).

Tabela 3. Biomassa da parte aérea (PA), parte radicular (PR) e Biomassa total das amostras $\left(1 \mathrm{~m}^{2}\right)$ de cinco diferentes populações de Guilandina bonduc que formam halos de solo nú localizados em pontos diferentes da llha da Trindade, e estimativa de concentração de exsudados liberados pelas raízes. 


\section{RESUMO}

As plantas podem liberar no ambiente diversos metabólitos secundários, que podem interferir de forma positiva ou negativa no crescimento e no desenvolvimento de espécies vizinhas. Esse fenômeno é conhecido como alelopatia. Um dos mecanismos para a liberação desses compostos aleloquímicos no ambiente é através da exsudação radicular. Guilandina bonduc (Fabaceae) forma halos de solo desprovidos de vegetação na ilha de Trindade. Suas raízes chegam até a população de Cyperus atlanticus, espécie endêmica dessa ilha que está sofrendo ação da expansão de $G$. bonduc. Portanto os objetivos desse trabalho foram analisar a atividade fitotóxica dos compostos presentes nos tecidos radiculares e no exsudado da raiz de $G$. bonduc e identificar compostos envolvidos nessa interação. Os exsudados radiculares de $G$. bonduc foram obtidos através de meio hidropônico, e os extratos aquoso e metanólico foram obtidos de raízes coletadas na llha da Trindade. A atividade biológica dos extratos foi testada no crescimento inicial de Lactuca sativa e Raphanus sativus nas concentrações de 125, 250, 500, 1000 e 2000ppm realizados em placas de Petri. A atividade dos exsudados radiculares coletados aleatoriamente também foram avaliadas sobre as mesmas espécies alvo. Foi realizada a estimativa da concentração dos exsudados liberados em campo. Também foram avaliadas as respostas do extrato aquoso nas mesmas concentrações utilizadas no bioensaio em placas, no solo coletado na llha da Trindade e com presença e ausência da microbiota. O produto isolado a partir do extrato metanólico foi identificado por RMN e a

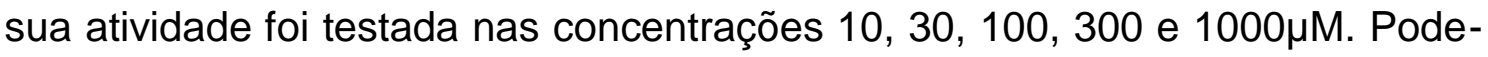
se observar que houve uma correlação negativa entre a produção de exsudados em laboratório e a biomassa total da planta. A estimativa da concentração dos exsudados liberados em campo condiz com as concentrações testadas nos bioensaio. Exsudados radiculares e o extrato aquoso estimularam o crescimento das espécies alvo, já o extrato metanólico inibiu o crescimento inicial das espécies alvo, sendo o efeito mais pronunciado na parte radicular. $O$ extrato aquoso, metanólico e exsudados radiculares apresentaram perfis cromatográficos distintos, mostrando que são diferentes quantitativamente e qualitativamente. $O$ extrato quando adicionado ao solo diferiu do resultado encontrado em placas de Petri sendo que não apresentou efeito significativo no crescimento das espécies alvo. Comparando-se os resultados obtidos, adicionado extrato aquoso no solo com presença e ausência de microbiota, observou-se que não houve diferença estatística no crescimento inicial das espécies alvo. $O$ produto isolado a partir do extrato metanólico é um cassanofuranoditerpeno conhecido como Caesaldekarin $\mathrm{C} \mathrm{e}$ esse apresentou atividade fitotóxica semelhante ao extrato bruto, mas de forma reduzida, apontando para um efeito sinérgico. 
Palavras chave: Guilandina bonduc, Fitotoxicidade, exsudados radiculares, Caesaldekarin C 


\section{ABSTRACT}

Plants emit a variety of secondary metabolites, that can influence negative or positively on the growth and development of neighbor species. Such phenomenon is called allelopathy. One of the mechanismes for emission of allelochemicals is through root exudate. It has been noticed that there are halos of bare soil around Guilandina bonduc ( Fabaceae) and its roots reach a population of Cyperus atlanticus, a endemic specie of the Trindade Island, that are suffering with $G$. bonduc expansion. Therefore, this work aimed to investigate phytotoxic activity of compounds in the root tissue and in the exudate of $G$. bonduc root and to identify compounds in this interaction. Root exudate of $G$. bonduc were obtained in hydroponic mean, and roots collected in the field (Trindade Island) provided aqueous and methanol extracts. Biological activity of the extracts were tested considering the initial growth of Lactuca sativa and Raphanus sativus grown in petri dishes in the concentrations of 125, 250, 500, 1000 and 2000ppm of extracts. Activity of root exudate randomly collected was also tested against the same species as above. It was also estimated the concentration of exudates in the field. Activity of aqueous extract, at the same concentrations mentioned previously, was also investigated using soil collected in the field, at Trindade Insland, with and without microorganisms. It was isolated one product from methanolic extract, identified using NMR, and its activity was tested at the concentrations of $10,30,100,300$ and $1000 \mu \mathrm{M}$. There was a negative correlation between root exudates production in the laboratory and plant total weight. Estimated concentration of exudate in the field was similar to the ones used in the laboratory bioassays. Root exudate and aqueous extract stimulated growth of tested species. On the other hand, methanolic extract inhibited initial growth of the same species, especially in the roots. Aqueous and methanolic extracts together with root exudate revealed different chromatographic profiles; showing that each was quantitatively and qualitatively different. Results of bioassay of aqueous extract in the soil were different to the one in petri dishes - there was no significant difference in the growth of tested species. The isolated product from methanolic extract is a cassane furanoditerpene, known as Caesaldekarin C. It showed phytotoxic activity similar to total extract, however lower, suggesting a synergistic effect.

Key-words: Guilandina bonduc, phitotoxicity, root exudates, Caesaldekarin C 


\section{Introdução}

\subsection{Metabolismo secundário}

O conjunto de reações químicas que ocorrem nos organismos vivos é conhecido como metabolismo, que trabalha prioritariamente em processos que sintetizem substâncias orgânicas, essenciais à sua sobrevivência e reprodução, como carboidratos, proteínas, gorduras e ácidos nucleicos, sendo estes pertencentes ao metabolismo primário. Esses metabólitos têm reconhecidas funções nos processos de fotossíntese, respiração, transporte de solutos, síntese proteica, translocação, assimilação de nutrientes e diferenciação. Tais substâncias são amplamente distribuídas e com alto grau de conservação entre os organismos vivos (García \& Carril, 2009).

Já os metabólitos secundários, produtos secundários ou, produtos naturais como também são popularmente conhecidos, não apresentam função definida nesses processos citados (Dewick, 2002). O que os diferem também dos metabólitos primários, é que os metabólitos secundários envolvem componentes que tem distribuição mais restrita e menos conservada entre os organismos. Nem todos os metabólitos secundários são encontrados em todos os grupos de plantas, podendo sua produção estar restrita a um determinado gênero de plantas, a uma família ou em apenas algumas espécies (García \& Carril, 2009).

Os produtos do metabolismo secundário das plantas são biossintetizados em várias organelas celulares, porém estocados em estruturas secretoras especializadas - como ductos, vacúolos, parede celular, superfícies cerosas - como forma de proteger os processos metabólicos da planta de seus efeitos tóxicos. Esses compostos secundários normalmente não são tóxicos para seus produtores e apresentam baixo custo metabólico para sua produção. Tais metabólitos podem favorecer a planta produtora em vários aspectos inclusive uma maior adaptação reprodutiva para suas plantas produtoras, que deixarão maior número de descendentes as quais herdarão suas características de defesa (Alves et al., 2002; Taiz \& Zeiger, 2009).

As plantas produzem metabólitos secundários em diferentes níveis de concentração, sendo determinado pelas características genéticas das espécies que os produzem e condições ambientais em que as plantas são encontradas, como: temperatura, umidade e intensidade de luz, adicionado aos efeitos da 
biota e composição físico-químicas do solo, podendo assim afetar não apenas a produção dos metabólitos, mas também a estrutura química e grau de atividade de substâncias liberadas para o meio (Almeida, 1991; Hadacek 2002; Macias et al., 2007; Reigosa et al., 2013).

As plantas possuem como caraterística serem sésseis, já que permanecem no mesmo local onde germinaram, impedindo-as de escapar quando se encontram sob ameaça. Esta característica tem sido compensada com outros mecanismos de defesa, subdivididos em mecânica, fenológica e química. Entre as defesas mecânicas, encontra-se a formação de acúleos e espinhos, aumento da dureza foliar, e presença de tricomas. Nas defesas fenológicas, as plantas ajustam seu ciclo biológico, minimizando assim condições de estresses abióticos ou diminuindo a disponibilidade de plântulas quando os herbívoros são mais ativos. E como último exemplo de defesa, a química, utiliza compostos do metabolismo secundário que atuam em resposta a algum estresse ocasionado na planta, como a herbivoria (Oliveros-Bastida, 2008). Os metabólitos secundários podem ser classificados em três grandes grupos: terpenos, compostos fenólicos e compostos nitrogenados, seguindo Taiz \& Zeiger, (2009) e Gleason \& Chollet (2012).

Alguns produtos do metabolismo secundário apresentam funções específicas, como na defesa contra fungos, bactérias e vírus, como sinalizadores para comunicação entre plantas e organismos simbiontes e também para proteção contra luz ultravioleta (UV) e estresses físicos (Wink, 2010).

Estes produtos, também atuam como atraentes ou repelente de animais proporcionando a planta sabores amargos, tornando-a indigesta ou venenosa como, por exemplo, os piretróides produzidos por Chrysanthemum cinerariaefolium que atuam como inseticida natural (Viegas Jr, 2003; Wink, 2010). Muitos desses metabolitos são pigmentos que proporcionam cor a flores e frutos, desempenhando um papel essencial na reprodução, atraindo insetos polinizadores, ou atraindo animais que se alimentam dos seus frutos, contribuindo dessa forma na dispersão de suas sementes (García \& Carril, 2009).

Os produtos do metabolismo secundário, apesar de sua grande variedade estrutural, são originários de um número restrito de rotas 
biosintéticas com precursores que derivam das rotas metabólicas primárias como o ciclo de Krebs, a glicólise ou a rota do chiquimato (Wink, 2010). Os principais produtos empregados na biossíntese dos metabólitos secundários são derivados da acetil-coenzima $A$ (acetil-CoA), do ácido chíquimico e do ácido mevalônico (Figura 1) (Dewick, 2002).

Os terpenos constituem o grupo de metabólitos secundários, que são formados por unidades isoprênicas de cinco carbonos, o pirofosfato de isopentenila (IPP), ou seu isômero, pirosfosfato de dimetilalila (DMAPP) (Alves \& Santos, 2002; Maraschin \& Verpoorte, 1999). Os terpenos são formados a partir da rota do ácido mevalônico, que por sua vez é resultado de uma sequência de reações químicas que ligam três moléculas de acetil -CoA. Os terpenos também podem ser formados a partir de um conjunto de reações denominado Rota do Metileritritol Fosfato (MEP) onde o IPP também pode ser formado (Taiz \& Zeiger, 2009).

Os compostos fenólicos constituem um grupo bastante heterogêneo, e são biossintetizados por duas diferentes rotas: a rota do ácido chiquímico e a rota do ácido malônico. A rota do ácido chiquímico pode dar origem a dois grupos de metabólitos, os compostos fenólicos e os compostos nitrogenados, pois a rota converte precursores de carboidratos derivados da glicólise e da rota da pentose-fosfato em aminoácidos aromáticos e esses darão origem aos compostos nitrogenados e os compostos fenólicos. A rota do ácido malônico, embora seja uma fonte importante de produtos secundários fenólicos em fungos e bactérias, é menos significativa nas plantas superiores (Taiz \& Zeiger, 2009).

Os alcaloides são um grupo com mais de 15.000 metabólitos secundários já conhecidos. São compostos que ocorrem naturalmente, sobretudo no reino vegetal, mas muitos podem ser encontrados em microrganismos, insetos e animais marinhos (Ávalos-García \& Carril, 2009; Gleason \& Chollet, 2012; Gómez-Archila et al, 2014,), e possuem como característica em comum como: ser solúveis em água, conter pelo menos um átomo de nitrogênio na molécula e exibem atividade biológica. São encontrados em aproximadamente $20 \%$ das plantas vasculares, sendo a maioria dicotiledôneas herbáceas (Ávalos-García \& Carril, 2009). São compostos nitrogenados, sintetizados principalmente a partir de aminoácidos 
aromáticos e a maioria são heterocíclicos Os alcalóides são sintetizados normalmente a partir da lisina, tirosina e triptofano e são classificados em função dos anéis presentes na sua molécula (Ávalos-García \& Carril, 2009).

Nas plantas alguns compostos nitrogenados possuem a função de defesa contra herbivoria (Taiz \& Zeiger, 2009). Alguns alcalóides, são mundialmente usados na medicina para redução da dor, como é o caso da morfina e da codeína.

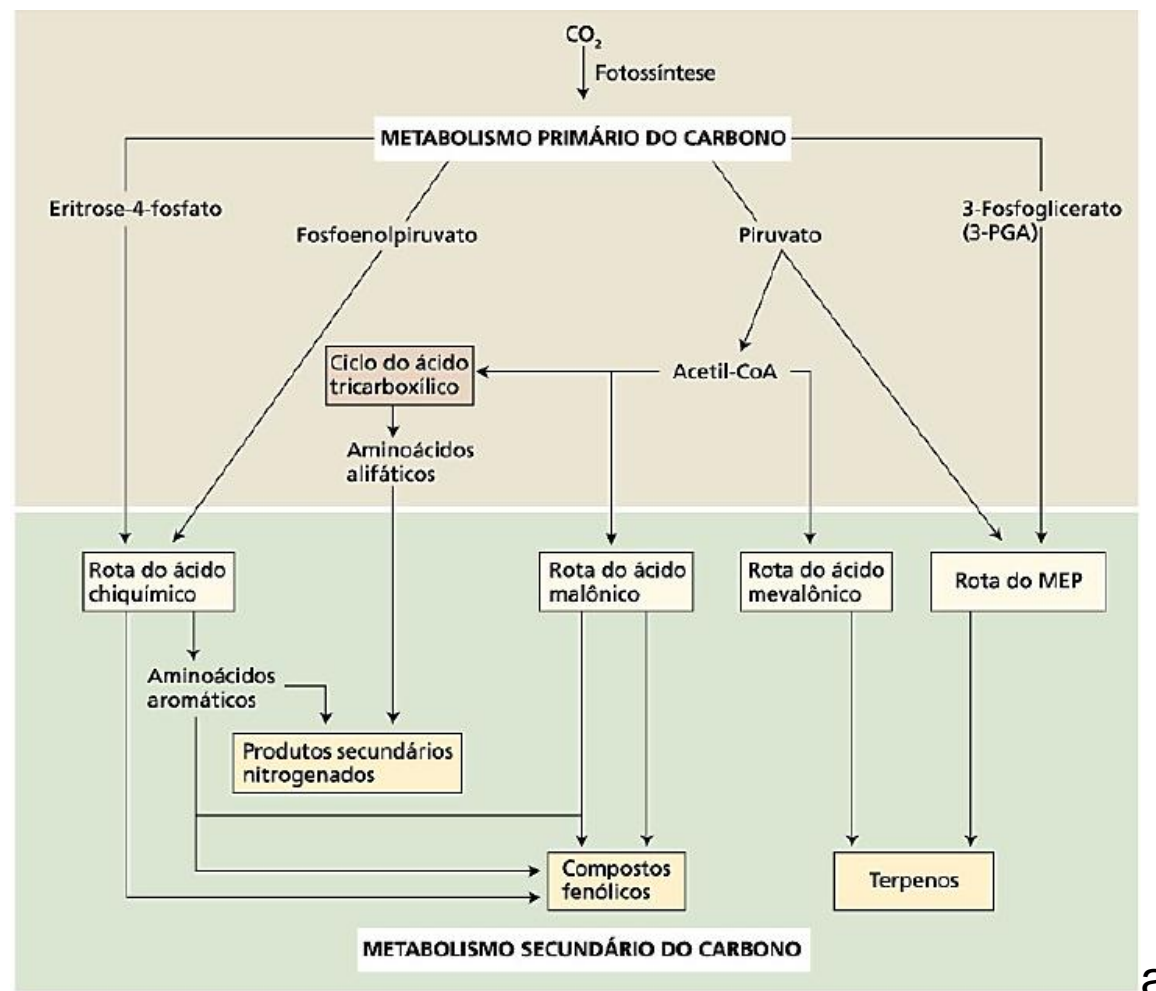

Figura 1. Visão simplificada das principais rotas de biossíntese de metabólitos secundários e suas inter-relações com o metabolismo primário. (Fonte: Taiz \& Zeiger, 2009)

\subsection{Alelopatia e fitotoxicidade}

As plantas liberam no ambiente uma grande diversidade de metabólitos primários e secundários a partir das folhas, raízes e serapilheira em decomposição (Gleason \& Chollet, 2012; Taiz \& Zeiger 2009).

A liberação de compostos secundários por uma planta que tem um efeito tóxico em outra planta (fitotóxico) é um fenômeno conhecido como alelopatia. A alelopatia pode ser descrita, como "processos envolvendo metabólitos secundários produzidos por plantas, algas, bactérias ou fungos que influenciam o desenvolvimento natural e sistemas agriculturais" (Sociedade Internacional 
de Alelopatia, 2012; Taiz \& Zeiger, 2009). Esses efeitos podem proporcionar vantagens contra plantas concorrentes, favorecendo a planta produtora. Rice (1974) definiu a alelopatia como sendo interações bioquímicas que produzem um efeito benéfico ou maléfico entre todos os tipos de plantas, incluindo os microorganismos. Este termo refere-se na interferência quimicamente mediada entre as plantas a fim de suprir o crescimento e a forma física de outras espécies (Murrell et al., 2011). Dentro deste contexto, os metabólitos secundários envolvidos nas interações alelopáticas foram designados de aleloquímicos (Reigosa et al., 2013; Whittaker \& Feeny 1971).

A alelopatia é um fenômeno totalmente natural e tem sido reconhecida como um importante mecanismo ecológico que influência a dominância vegetal, a sucessão, a formação de comunidades vegetais e de vegetação clímax (Carvalho, 1993; Ferreira, 2004).

Estudos alelopáticos também podem ser confundidos com estudos de fitotoxicidade. No entanto, existem diferenças entre as metodologias aplicadas na extração dos metabolitos que distinguem um do outro. Um estudo de alelopatia é realizado apenas com aleloquímicos extraídas a partir do tecido das plantas alvo, utilizando métodos naturais que possa simular o que ocorre naturalmente na natureza, tais como lixiviação, volatilização, a exsudação e a decomposição do tecido vegetal; ou obtidas sob condições de laboratório, simulando um processo natural, tais como a extração aquosa a partir de tecido de planta. Em contraste, os estudos de fitotoxicidade extraem os aleloquímicos por meio de qualquer processo químico que não é natural, como por exemplo utilizando solventes orgânicos, tais como o hexano, diclorometano e metanol (Blum,2011; Reigosa, et al. 2013).

As interações químicas entre as plantas quase nunca são limitadas a um composto, mas sim uma mistura de vários compostos (Gonzalez \& Reigosa, 2001). O nível de toxidade das substâncias e de interação entre os organismos também dependem do estádio de crescimento da espécie doadora e da espécie receptora. (González \& Reigosa 2001; Rice 1974).

Ao longo dos anos, tem-se comprovado que as plantas produzem substâncias químicas com propriedades alelopáticas que possuem especificidade, afetando ou não determinadas espécies de plantas. (Rezende et al., 2003). Essas substâncias químicas são distribuídas em concentrações 
variadas das diferentes partes das plantas e durante o seu ciclo de vida (periodicidade), e quando liberadas ao meio em quantidades suficientes podem causar efeitos alelopáticos sobre as plantas vizinhas.

Os quatro mecanismos que têm sido propostos para a liberação dos aleloquímicos no ambiente são quatro: volatilização, lixiviação, decomposição e exsudação. Dessa forma os aleloquímicos podem ser absorvidos por outras plantas, afetando seu padrão de crescimento e desenvolvimento (Ferreira, 2004; Oliveiros-Bastidas et al. 2009) (Figura 2).

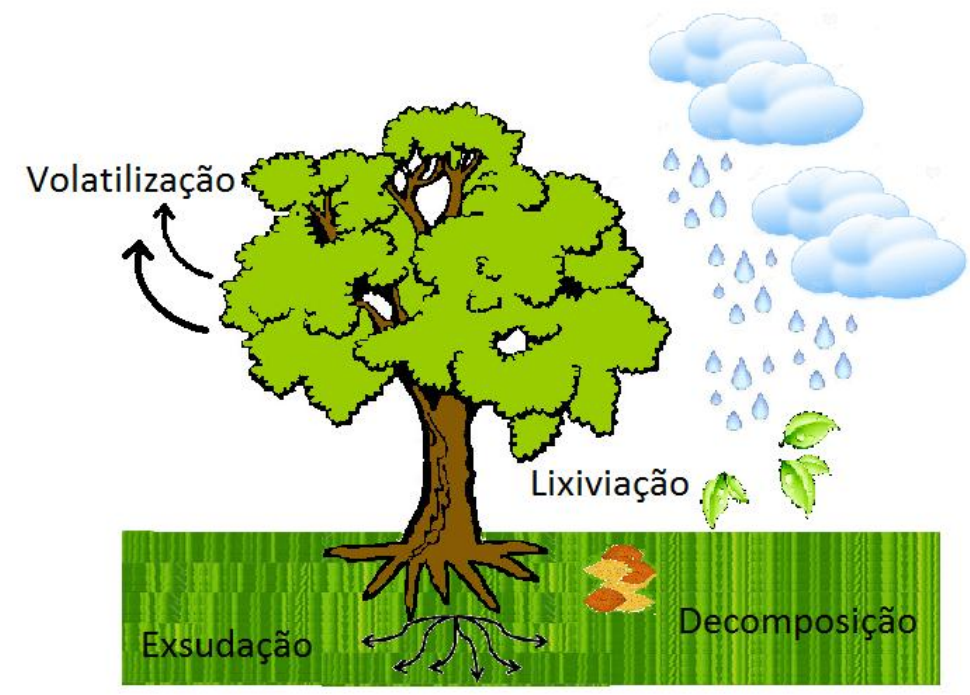

Figura 2. Modo de liberação dos metabólitos secundários pelas plantas.

As condições ambientais em que as plantas são encontrados como: temperatura, umidade e intensidade de luz, adicionado aos efeitos da biota e composição físico-químicas do solo, podem assim afetar não apenas a produção dos metabólitos, mas também a estrutura química e grau de atividade de substâncias liberadas para o meio (Almeida, 1991; Hadacek 2002; Macias et al., 2007; Reigosa et al., 2013).

Para designar a interferência no crescimento devido a produtos químicos, o termo alelopatia não deve ser utilizado até que haja dados disponíveis sobre a liberação natural dos compostos a partir da planta doadora, a concentração e persistência destes compostos no meio ambiente, e o envolvimento direto dos mesmos com a inibição/estímulo da planta-alvo (Inderjit et al., 2001). Resumidamente o estudo alelopático precisa englobar o mecanismo de liberação do aleloquímico e sua estabilidade no ambiente, o que irá definir os níveis e a forma com que o organismo receptor o absorverá, além 
dos inúmeros modos de ação encontrados que podem depender de cada receptor (Blum, 2011; Oliveros-Bastida, 2008).

\subsection{Exsudação radicular}

A raiz é geralmente referida como "a metade oculta" de uma planta, apresentando padrões arquitetônicos e de crescimento muito complexos, os quais são definidos principalmente pelo tipo de planta, estrutura do solo e as interações entre eles (Badri \& Vivanco, 2009; Comas et al, 2013; OliveirosBastidas et al., 2009).

Além da sustentação e absorção de nutrientes e água, as raízes possuem outras funções de importância vital para a sobrevivência e adaptação , como a síntese, armazenamento e liberação de compostos que interferem nos padrões populacionais intra e inter espécies (Badri \& Vivanco, 2009; OliveirosBastidas et al., 2009). A capacidade para liberar uma grande variedade de compostos para a rizosfera é uma das características metabólicas mais notáveis das raízes das plantas, com cerca de 5-21\% de carbono total fotossínteticamente fixado a ser transferido para a rizosfera através da exsudação radicular (Derrien et al, 2004, Marschner, 1995; Nguyen, 2003; Whipps, 1990.).

Os exsudados consistem principalmente de compostos à base de carbono, mas podem conter também íons livres e ácidos inorgânicos de oxigênio e de água. (Bais et al. 2006; Uren, 2000). Essas substâncias orgânicas podem muitas vezes ser separados em duas classes: compostos de baixo peso molecular, que incluem aminoácidos, açúcares, ácidos orgânicos, compostos fenólicos e um conjunto de metabólitos secundários, e compostos de alto peso molecular, tais como proteínas e mucilagem (Badri \& Vivanco, 2009; Bais et al. 2006).

A interface raiz-solo é um ambiente com alto potencial de desenvolvimento de microorganismos, que podem ser patogênicos e/ou benéficos (Rouatt \& Katznelson, 1960). Assim, as raízes das plantas estão constantemente expostas a uma vasta microbiota que interagem e se defendem de acordo com o tipo de estresse biótico (Bais et al., 2004 ;2006), e essas interações podem afetar a exsudação radicular. 
No entanto, a quantidade e composição de exsudados de raízes é influenciado por muitos fatores como estresse bióticos e abióticos (Badri \& Vivanco, 2009; Jones et al., 2004), incluindo a estrutura do solo (Berg \& Smalla, 2009), a presença de microorganismos (Groleau-Renaud et al., 2000), as espécies de plantas, bem como a sua fase de desenvolvimento (Gransee \& Wittenmayer, 2000) e o estado nutricional (Hinsinger, 2001; Lesuffleur et al., 2007; Marschner, 1998).

Algumas das interações mais complexas vividas por plantas terrestres, sejam elas químicas, físicas ou biológicas são aquelas que ocorrem entre as raízes e a região de solo circundante (rizosfera). No entanto, segundo Bais e colaboradores (2006), as raízes por serem subterrâneas muitos dos fenômenos envolvidos em tais interações têm permanecido praticamente despercebidas.

A sinalização química entre as raízes das plantas e outros organismos do solo, incluindo raízes de plantas vizinhas, é baseada em produtos químicos derivados das raízes. Os mesmos sinais químicos podem desencadear respostas diferentes a partir de diferentes destinatários. Os componentes químicos liberados podem dissuadir um organismo e ao mesmo tempo atrair outro, ou até dois organismos muito diferentes podem ser atraídos com diferentes consequencias para a planta (Bais et al., 2006).

Diferentes substâncias encontradas em exsudados radiculares podem afetar a produção de metabólitos (Einhelling, 1995; Weir et al. 2004), a respiração (Peñuelas, et al., 1996), fotossíntese (Chen et al., 2002), transporte de membrana ( $\mathrm{Li}$, et al.,2010), e inibição/estímulo do crescimento da raiz e parte aérea em plantas suscetíveis (Cruz-Ortega, et al., 1998; Cruz-Ortega, et al., 2007). Por exemplo, um potente aleloquímico conhecido como Juglone produzido pelas raízes das plantas de nogueira preta (Juglans nigra L.), atua como um doador e o receptor de elétrons na fotossíntese e respiração, afetando esses processos em plantas que são suscetíveis a substância liberada pela espécie (Jose \& Gillespie, 1998).

A relevância ecológica dos exsudados fitotóxicos também depende da susceptibilidade das plantas com os quais as plantas alelopáticos coexistem. Além disso, os metabólitos secundários podem inibir a atividade microbiana do solo e a macrofauna, reduzindo assim as taxas de decomposição e 
consequentemente reduzindo ainda mais a disponibilidade de nutrientes no solo (Bais et al., 2006, Wardle \& Lavelle, 1997).

Plantas perenes que apresentam potencial alelopático, têm maiores chances de manter os níveis fitotóxicos dos aleloquímicos apesar da degradação microbiana, pois elas mantêm a reposição contínua e periódica dos compostos aleloquímicos no solo, ou produzem compostos resistentes a degradação microbiana (Inderjit, 2005). Estes efeitos sobre a fisiologia da planta, crescimento e sobrevivência, por sua vez influência a composição e a dinâmica da comunidade do solo (Bais et al.; 2006; Ferreira \& Aquila, 2000).

Estudos realizados com Centaurea maculosa Lam, uma espécie conhecida pelo seu potencial de invasão no oeste dos Estados Unidos, particularmente em pradarias e pastagens, um flavónoide chamado catequina foi identificado nos seus exsudados radiculares. Este composto apresenta forte efeito inibitório sobre várias espécies de plantas e é considerado como um dos principais fatores para a sua invasão bem sucedida em uma diversidade de ambientes (Bais et al, 2003;. Weir et al., 2003). Outro aleloquímico secretado pelas raízes da planta daninha Phragmites australis (Cav.) Trin. ex Steud., foi identificado como ácido gálico, que é considerado um potente composto para a sua invasão bem-sucedida no pântano e comunidades de zonas úmidas, deslocando as espécies nativas (Rudrappa et al. 2007).

Os exsudados de raízes têm o potencial de influenciar três mecanismos de interferência que podem levar a interações negativas entre as plantas: interferência química, parasitismo e competição de recursos (Bais et al., 2006). Para um número de espécies de plantas, exsudados radiculares desempenham um papel direto como fitotoxinas na mediação interferência química (ou seja, a alelopatia). Além disso, exsudados radiculares são fundamentais para 0 desenvolvimento de associações entre algumas plantas parasitas e seus hospedeiros. É o que ocorre com as sementes das plantas parasitas Striga sp. e Orobanche $s p$, que são capazes de reconhecer produtos como strigolactonas, as quinonas e sorgoleone que são exsudados pelas raízes das plantas hospedeiras, e consequentemente a germinação ocorre quando os receptores das sementes detectam a presença destes produtos. A radícula entra em contato com a raiz do hospedeiro e penetra no tecido da raiz (Galindo et al., 2003; Macias et al., 2006). As plantas podem interagir de forma negativa 
quando os exsudados liberados pelas raízes podem criar associações com plantas parasitas, micróbios patogênicos e herbívoros invertebrados (Bais et al., 2006; Zahar Haichar et al., 2014). Finalmente, exsudatos radiculares podem desempenhar papéis importantes na competição indireta por recurso, alterando a química do solo, processos do solo, e as populações microbianas.

Interações positivas entre as plantas também são, por vezes controladas pelos exsudados radiculares. Essas interações positivas incluem associações simbióticas com micróbios benéficos, como os rizóbios, micorrizas e rizobactérias promotoras do crescimento (PGPR - plant growth promoting rhizobacteria) (Zahar Haichar et al., 2014). Em particular, alguns exsudados radiculares induzem respostas de defesa em plantas vizinhas. Em alguns casos, as defesas de plantas induzidas por exsudados radiculares simplesmente reduzem a susceptibilidade à infecção por patógeno (De-la-Pena et al., 2008; Zahar Haichar et al., 2014), enquanto que em outros casos, essas defesas iniciam a produção e liberação de substâncias voláteis que atraem os predadores de inimigos das plantas (Rasmann, et al. 2012). Além disso, os efeitos de exsudados radiculares em processos do solo e populações microbianas pode levar a alguns efeitos positivos sobre as plantas vizinhas incluindo associações simbióticas com microrganismos benéficos, tais como micorrizas e rizobactérias promotoras do crescimento das plantas (Bais et al, 2006; Philippot et al, 2013; Zahar Haichar et al., 2014).

A liberação de exsudado de raízes é uma das estratégias utilizadas por plantas invasoras para o seu sucesso adaptativo. As plantas invasoras não costumam ser invasivas em sua área nativa onde são mantidos supostamente sobre controle pela presença de insetos e patógenos, entre outros fatores especializados. Todavia, essas plantas se tornam altamente invasivas no ambiente introduzido (novos) onde esses insetos ou patógenos não estão presentes. Poderia ser possível inferir que a espécie nativa no entorno de plantas e a interação global das plantas com a sua comunidade de plantas nativas pode mantê-lo sob controle, através da modulação de certos parâmetros fisiológicos ou bioquímicos como favorecendo a defesa, em comparação com o crescimento. Quando uma planta com potencial de invasão chega a um novo local onde essas interações evolutivas com os vizinhos de plantas não estão presentes, a sua bioquímica e fisiologia poderiam ser 
alteradas para favorecer o crescimento (Badri \& Vivanco 2009). Mais especificamente, a hipótese descrita por Callaway e Ridenour (2004), "Novel weapons hypothesis" sugere que o sucesso de algumas espécies invasoras em ambientes novos, devem seu sucesso à produção de produtos bioquímicos que não são produzidas pelas plantas nativas no local de invasão. Esses produtos, portanto, podem ter o potencial para exercer efeitos mais fortes sobre espécies nativas que não tem tolerância co-evolucionária do que os concorrentes coevoluídos da área de distribuição natural (Thorpe et al., 2009).

Estudos realizados por Callaway \& Aschehoug (2000), encontraram que Centaurea diffusa Lam, uma erva daninha da Europa, tem efeitos negativos mais pronunciados sobre espécies de gramíneas da América do Norte, inibindo seu crescimento em até $70 \%$, do que intimamente relacionados às espécies de gramíneas das comunidades em que Centaurea é nativa. A vantagem de Centaurea sobre espécies norte-americanas parece ser devido a diferenças nos efeitos de seus exsudados radiculares e como esses afetam a concorrência por recursos. Os efeitos menos agressivos de exsudados de espécies invasoras em seus antigos vizinhos e os efeitos mais agressivos dos mesmos exsudados nos vizinhos novos, sugerem que as plantas podem adaptar-se a possuir uma tolerância à bioquímica das espécies que coexistem (Callaway \& Ridenour, 2004). Estes resultados podem ajudar a explicar por que algumas espécies exóticas conseguem invadir com sucesso outras comunidades nativas.

As plantas são continuamente expostas a uma variedade de inimigos naturais, incluindo fungos patogênicos, bactérias, vírus, nematódeos e artrópodes que se alimentam de suas raízes. Como resposta à ação de tais organismos, e para conferir resistência para o tecido radicular, as plantas liberam exsudados biologicamente ativos na rizosfera. Esses exsudados radiculares são conhecidos por terem diversas funções nas interações ecológicas com plantas vizinhas e as comunidades microbianas do solo, atuando como moléculas não só de sinalização, atrativos e estimuladores, mas também como inibidores ou repelentes (Baetz \& Martinoia, 2014).

Foram realizados trabalhos mostrando a importância dos exsudados radiculares em solos com níveis tóxicos de alumínio, onde as plantas exsudam para o meio compostos orgânicos e compostos fenólicos, que formam 
complexos com o alumínio diminuindo assim a sua fitotoxicidade (Barceló \& Poschenrieder, 2002; Kidd et al, 2001). Em outro estudo realizado por Liu, et al.(2015), os exsudados radiculares de Festuca arundinacea L. apresentaram capacidade de facilitar a fitorremediação de solos contaminados com petróleo.

Já estudos na interação planta-planta entre Heracleum mantegazzianum Sommier \& Levier, considerada planta invasora da República Tcheca e Plantago lanceolata L., espécie nativa do local, mostrou que o exsudado radicular da espécie invasora apresentou efeito inibitório no crescimento radicular de $P$. lanceolata, onde possivelmente o sucesso invasivo da espécie pode ser relacionado aos metabólitos liberados pela exsudação radicular da espécie.

O sistema de defesa das plantas mediada pela exsudação radicular e sua regulação são essenciais para a sobrevivência da planta e nos processos biológicos, cada vez mais representa uma importante área de interesse em estudos da biologia das raízes. O crescente número de estudos referente a diversidade metabólica de exsudados e tecidos radiculares está sendo gradualmente elucidada e caracterizada por diversos compostos novos com capacidade antimicrobiana e grupos responsáveis pela defesa direta das plantas (Baetz \& Martinoia, 2014).

\subsection{Espécie de estudo e local}

Durante estudos realizados na llha da Trindade, Alves e colaboradores (2011) observaram a presença de halos de solo nu ao redor da espécie introduzida Syzygium cumini (L.) Skeels que se acreditava ser exótica na Ilha, a qual impede o estabelecimento da espécie Cyperus atlanticus Hemsl, espécie endêmica da ilha, descrita pela primeira vez por Hemsley em 1884, (Alves, 1998). Os autores relacionaram tal efeito a alelopatia. Em junho de 2012 pesquisadores da Universidade de Brasília observaram grande número de halos em diversos locais da llha, possíveis de se avistar a quilômetros de distância, mas ao contrário do descrito em situações anteriores, os halos de plantas mortas e solo nu não se formam exclusivamente ao redor de plantas introduzidas, mas também circundam agrupamentos de Guilandina bonduc L. O aparente efeito alelopático de $G$. bonduc na vegetação parece ser seletivo, 
não afetando outras espécies ocorrentes na ilha como Leucaena sp. e Dioclea sp., mas está sendo fatal para C. atlanticus (Carvalho et al., 2013).

Durante novas expedições realizadas, foi possível constatar que as raízes de $G$. bonduc chegavam até a população de $C$. atlanticus (Figura 3), levando-se então a pensar que esta espécie pode estar liberando fitotoxinas no meio, que está impedindo o estabelecimento de $C$. atlanticus. Esta interferência pode levar a uma redução significativa da espécie endêmica na ilha, podendo levar a espécie a extinção a médio e longo prazo. Portanto, faz-se necessário o estudo das substâncias liberadas pelas raízes e a identificação das fitotoxinas que podem estar atuando na interação entre as espécies, pois os mesmos podem estar ligados aos efeitos que estão ocorrendo na llha.

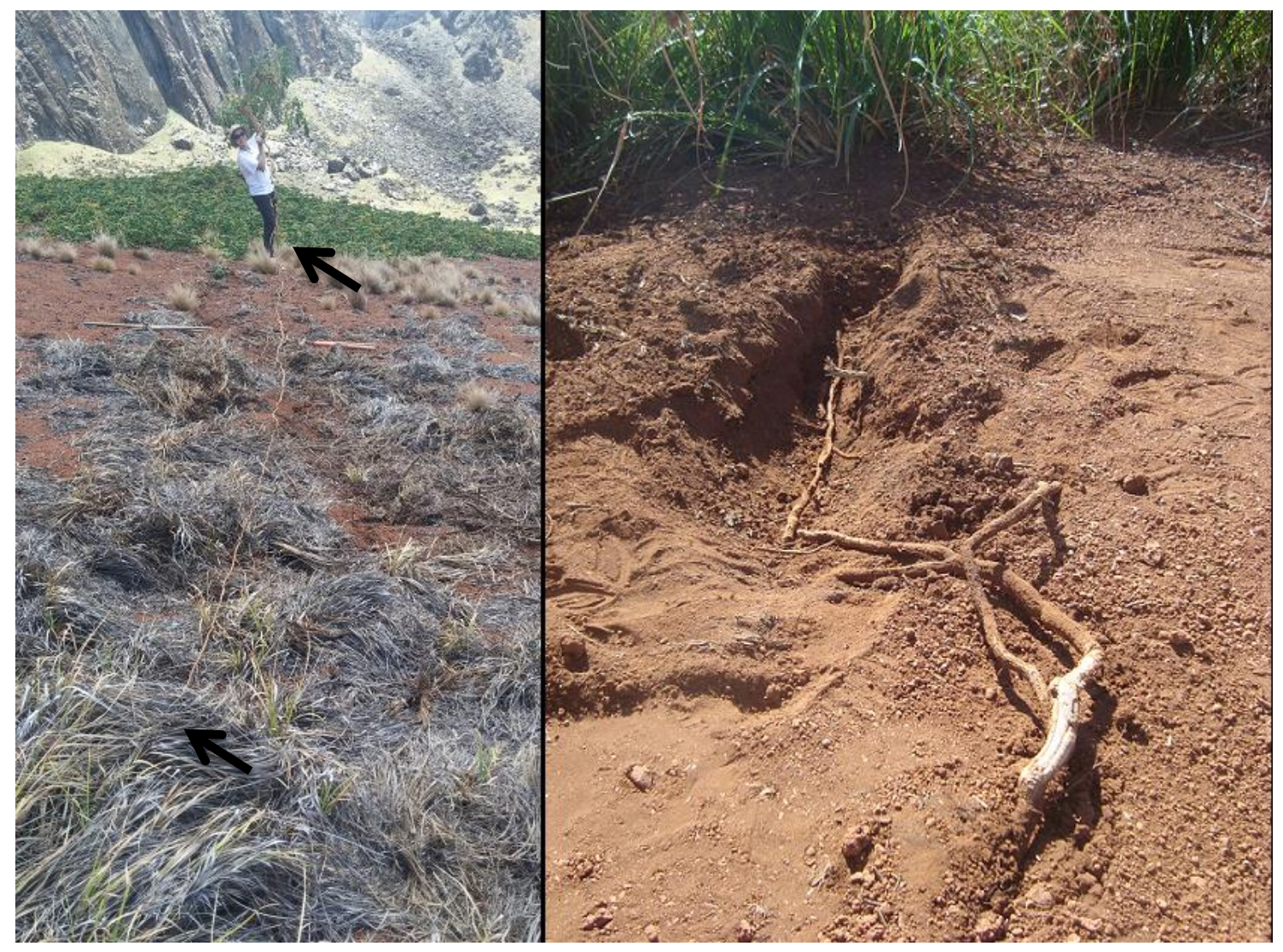

Figura 3. Raízes de Guilandina bonduc se estendendo até as populações de Cyperus atlanticus Hemsl.

Guilandina bonduc L., uma planta pertencente à família Fabaceae, (Caesalpinoideae) que tem por sinonímia Caesalpinia bonduc e Caesalpinia bonducella (Gunn \& Dennis, 1999; Perry IV \& Dennis, 2003). Essa espécie possui distribuição pantropical e é comum nas ilhas do atlântico sul e litoral do Brasil (Alves, 1998; Carvalho et al., 2013; Lewis et al., 2005Além disso também 
pode ser encontrada nas regiões tropicais e subtropicais da Ásia e Caribe (Chakrabambrti et al, 2003;. Kinoshita, 2000).

G. bonduc é um arbusto espinhoso, que adquire aproximadamente 1,5 m de altura e $6 \mathrm{~m}$ ou mais de extensão. As plantas de $G$. bonduc possuem caules, galhos e folhas cobertos de espinhos e formam raízes laterais extensas (Francis, 2000). As suas sementes são capazes de flutuar por 30 anos ou mais, podendo ser carregadas pelas correntes marítimas. Essas também possuem habilidade de germinação após exposto por um longo período de tempo em água do mar, o que ajuda a explicar a sua ampla distribuição em ilhas e nas constas continentais, como nas regiões tropicais e sub-tropicais da África, Ásia e Caribe (Gunn \& Dennis, 1999; Gupta et al., 2003; Perry IV \& Dennis, 2003).

G. bonduc tem sido objeto de várias investigações químicas, devido o amplo uso na medicina popular, utilizando-se diferentes partes da planta como sementes e raízes, nos seguintes tratamentos: asma, febre, tosse, dor de cabeça e dor de estômago crônica (Yadav et al., 2009) e também uma variedade de atividades farmacológicas, tais como: atividade antimicrobiana e antifúngica (SIMIN et al. 2001), atividade adaptogênica (capacidade de aumentar a resistência do organismo a pressões físicas, químicas e biológicas) (Kannur et al., 2006), contração dos músculos lisos (Datte et al., 1998) e músculos esqueléticos (Datte et al., 2004) e atividade antifilarial (Gaur et al., 2008).

Estudos fitoquímicos realizados com partes da planta de $G$. bonduc revelaram a presença de flavonoides, terpenoides, glicosídeos, saponinas, taninos e alcaloides. Dentro desses grupos foram isolados diversos compostos descritos na Tabela 1. 
Tabela 1. Substâncias isoladas de diferentes partes da planta de Guilandina bonduc L. e a classe a qual pertence.

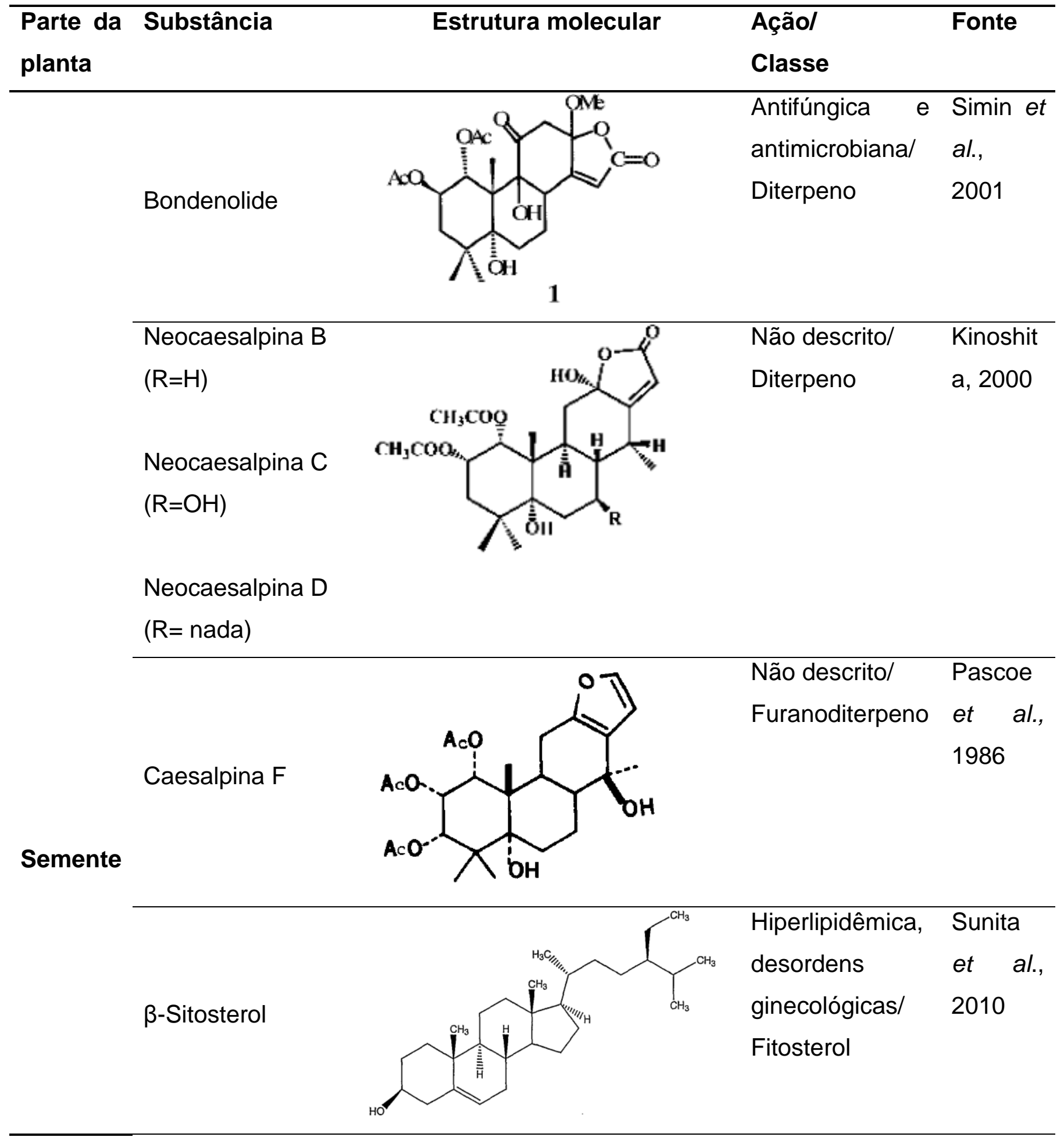




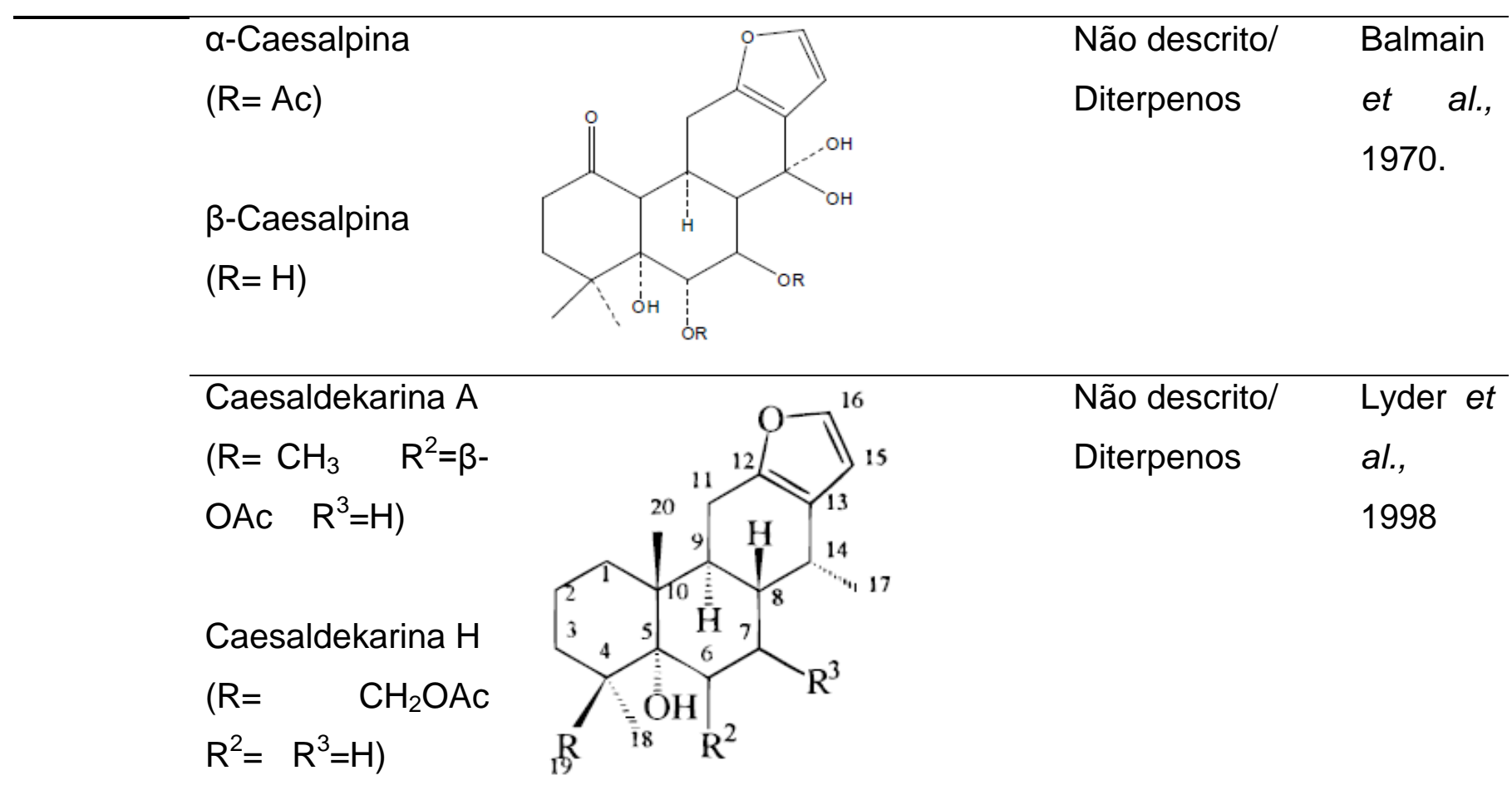

Demethylcaesald

ekarina C

$\left(\mathrm{R}=\mathrm{COOH} \quad \mathrm{R}^{2}=\right.$

$\mathrm{R}^{3}=\mathrm{H}$ )

Raiz Caesaldekarina I

$\left(\mathrm{R}=\quad \mathrm{CH}_{2} \mathrm{OH}\right.$

$\left.\mathrm{R}^{2}=\mathrm{H} \mathrm{R}^{3}=\beta-\mathrm{OH}\right)$

Caesalpinina

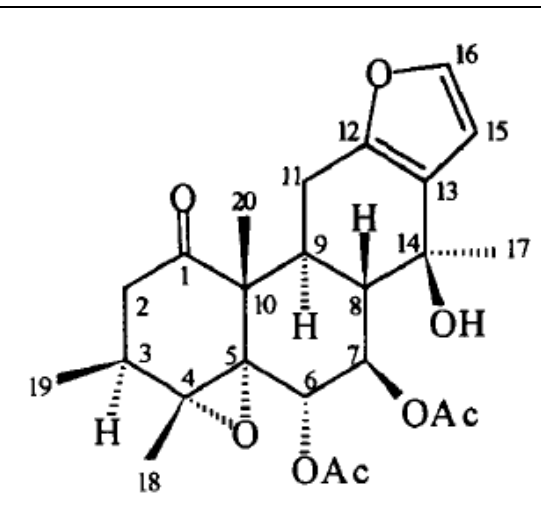

Não descrito/

Peter et

Furanoditerpeno al., 1997

$\mathrm{C}_{24} \mathrm{H}_{30} \mathrm{O}_{8}$ 
Alves (1998) relatou que $G$. bonduc tem sido encontrada em Trindade desde 1916, em expedições realizadas pelo Professor e Pesquisador Bruno Lobo do Museu Nacional do Rio de Janeiro.

A história humana na ilha começou juntamente com o início das grandes navegações e seu descobrimento é creditado, por alguns historiadores, ao navegador espanhol João da Nova, que teria descoberto Trindade em 1501. Contudo, outros historiadores afirmam que o português Estêvão da Gama, durante uma viagem às Índias, teria descoberto Trindade em 1502. Nessa ocasião, a ilha foi batizada, com o nome que conserva até hoje, em homenagem à Santíssima Trindade, em função das três elevações que se avistam de longe (Figura 4) (Gusmão, 2005).

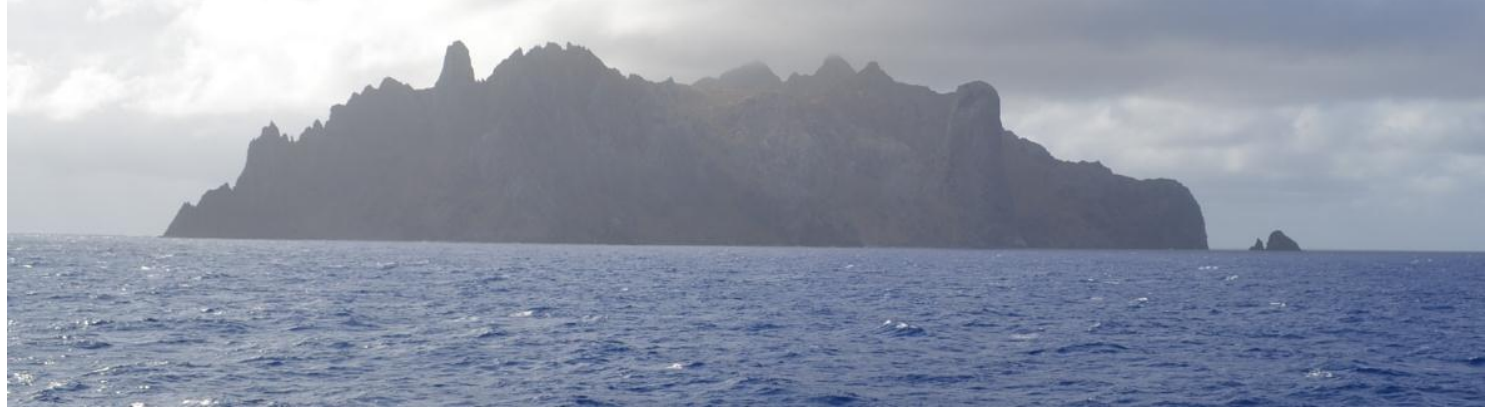

Figura 4. Perfil da Ilha da Trindade (Fonte: Bruno Rabelo)

A Ilha da Trindade é uma ilha oceânica Brasileira, que fica a 1.200 quilômetros de Vitória, capital do Estado do Espírito Santo, sendo administrada pela Marinha do Brasil (Silva \& Alves, 2011). Há estimativas de que a llha tenha emergido há cerca de três milhões de anos, em decorrência do vulcanismo básico e misto a qual deu origem a cadeia submarina VitóriaTrindade (Alves, 1998; Duarte \& Horta, 2012). A última atividade vulcânica ocorreu a aproximadamente cinco mil anos, resultando em um relevo extremamente acidentado, com encostas íngremes e vales profundos, distribuídos por uma extensão de aproximadamente $10 \mathrm{Km}^{2}$ (Duarte \& Horta, 2012). As profundidades oceânicas ao redor da ilha atingem $5800 \mathrm{~m}$, e a parte emersa da ilha atinge $620 \mathrm{~m}$ (Alves, 1998).

O clima de Trindade é oceânico tropical, sendo amenizado pelos ventos alísios do Leste e do Sudeste. A ilha possui uma temperatura média 
anual de $25^{\circ} \mathrm{C}$, sendo fevereiro o mês mais quente do ano, atingindo médias de $27^{\circ} \mathrm{C}$ e o de setembro o mais frio, sendo que a temperatura mínima chega a $21^{\circ} \mathrm{C}$. Quase todos os dias ocorrem chuvas rápidas, principalmente no verão, que recebem o nome de Pirajás. Entre os meses de abril e outubro, a llha sofre influência periódica de frentes frias, com intervalo médio de uma semana, que provocam alterações nas condições do mar (Gusmão, 2005).

A alta frequência de chuvas se deve à altitude dos picos da llha da Trindade. A altitude máxima da ilha está em torno de 600 metros acima do nível do mar, e dessa forma cria-se uma forte barreira para as nuvens carregadas, que precipitam após atingirem o paredão do pico da ilha. Essas chuvas mantêm três grandes fontes de água potável: uma na Enseada da Cachoeira, a mais abundante, outra na Praia do Príncipe e a terceira na Enseada dos Portugueses, que é utilizada pela população da ilha (Gusmão, 2005).

Em 1700, durante uma viagem pelo Atlântico Sul, Edmund Halley levou cabras, porcos e aves para a ilha esperando que estes servissem como recursos de sobrevivência para possíveis náufragos e ocupantes da ilha. Burros, gatos e ovelhas também foram introduzidos durante ocupações posteriores pelos britânicos (Silva \& Alves, 2011). Esses animais foram responsáveis por significativa degradação do ambiente nativo, principalmente as cabras, obrigando a posterior retirada dos mesmos e foi finalizada em 2005. Após a retirada das cabras, resultados positivos passaram a ser observados pelos cientistas, com destaque para a recuperação da vegetação local e os fluxos de água doce tem retomado os seus volumes iniciais (Martins \& Alves, 2007; Alves et al., 2011; Duarte \& Horta, 2012).

Dentre as espécies que tiveram sua população reestabelecida após a retirada das cabras, podemos citar a espécie Guilandina bonduc L. As plantas de $G$. bonduc possivelmente vinham servindo de alimento para as cabras, que assim controlavam as populações, impedindo sua expansão. Após a eliminação desses animais as populações de $G$. bonduc parecem estar se proliferando e agindo de forma negativa no estabelecimento de Cyperus atlanticus Hemsl, espécie endêmica da ilha, descrita pela primeira vez por Hemsley em 1884, (Alves, 1998). 


\subsection{Métodos gerais para obtenção de agentes fitotóxicos de plantas}

As buscas de uma avaliação mais realista do potencial alelopático das plantas têm dado origem a vários estudos com exsudado radiculares, as substâncias presentes nos mesmos, e sua associação com os efeitos biológicos. Metabolitos secundários produzidos por exsudados de raízes já foram identificados de diferentes espécies de plantas com propriedades alelopáticas, como sorgoleone (Uddin et al., 2014), momilactona B (Kong et al., 2004; Kato-Noguchi et al. 2002), ácido caféico (Mandal, 2001), ácido málico e fumárico (Kamilova et al., 2006). Muitos estudos têm demonstrado que as ações fitotóxicas correlacionam-se com os níveis de algumas dessas substâncias presentes nos exsudados. Essas evidências mostram que os exsudados podem ser responsáveis por esses efeitos alelopáticos no campo, o que corrobora com a hipótese de que a fitotoxina liberada para o ambiente é absorvida por uma espécie receptora sendo esses os requisitos básicos na demonstração da existência do fenômeno da alelopatia.

Sabendo da necessidade de se conhecer o potencial dos exsudatos radiculares e os aleloquímicos presentes, esses, tem sido alvo de estudo nos últimos anos. Metodologias para os estudos do potencial dos exsudados têm sido desenvolvidos para avaliar a atividade fitotóxica de espécies doadoras e receptoras, e que permite a análise do conteúdo de alguns compostos presentes nele.

Existem variações nas metodologias utilizadas para analisar exsudatos. Em geral, meios de hidroponia são utilizados para manter as plantas e seus exsudados, onde podem ser analisados diretamente na solução de cultura (Mandal, 2001; Stermitz et al., 2003; Kong et al., 2004, Ponce, et al. 2004, Zhang, et al., 2014). Em alguns casos utilizam um suporte sólido (Seal at al., 2004); como esferas de vidro (Sandnes et al., 2005), vermiculita (Park et al., 2004), areia (Thelen et al., 2005) ou ágar (Parvez, et al. 2003) para manter as culturas das plantas estudadas.

Melhorar o foco do trabalho 


\section{Objetivos}

Os objetivos deste trabalho são analisar a atividade fitotóxica das substâncias presentes nos tecidos e no exsudado da raiz de $G$. bonduc, bem como identificar metabólitos secundários envolvidos nessa interação.

\subsection{Objetivos Específicos}

- Extrair metabólitos presentes nos tecidos radiculares e no exsudado das raízes de Guilandina bonduc;

- Identificar extratos ativas através de bioensaios utilizando espécies alvo padrão;

- Identificar a natureza química das moléculas presentes nos extratos;

- Analisar o efeito dos extratos das raízes de Guilandina bonduc em solo da ilha de Trindade e do solo com ausência e presença de microbiota sobre espécies alvo padrão;

- Analisar o efeito do solo sobre espécies alvo padrão coletado abaixo das populações de Cyperus atlanticus, Guilandina bonduc e na formação do halo desprovido de vegetação;

- Estimar a produção de exsudado de raízes em condições de campo.

\section{Metodologia}

O estudo foi desenvolvido no laboratório de Alelopatia Alfredo Gui Ferreira e no laboratório de Termobiologia L.G. Labouriau, ambos pertencentes ao Instituto de Biologia, localizados no Campus Darcy Ribeiro, Universidade de Brasília.

Raízes de três populações de Guilandina bonduc foram coletadas na Ilha da Trindade durante expedições realizadas em outubro de 2013 e abril de 2014. As matrizes foram georreferenciadas, possuindo coordenadas $20^{\circ} 31^{\prime} 05,7^{\prime \prime} \mathrm{S} / 29^{\circ} 18^{\prime} 07,5^{\prime \prime} \mathrm{W}$; $20^{\circ} 51,6^{\prime} 31,5^{\prime \prime} \mathrm{S} / 29^{\circ} 30,9^{\prime} 29,9^{\prime \prime} \mathrm{W}$; $20^{\circ} 31^{\prime} 13,2^{\prime \prime} \mathrm{S} / 29^{\circ} 186,7$ 'W. As raízes foram secas a $50 \pm 2^{\circ} \mathrm{C}$ por 48 horas e trituradas em moinho de rotor tipo ciclone (TECNAL TE-625) para o posterior preparo dos extratos. 


\subsection{Obtenção do exsudado da raiz}

Para obter o exsudado de raiz, sementes de $G$. bonduc foram coletadas na Ilha da Trindade durante expedição realizada em outubro de 2013. As sementes foram escarificadas e colocadas para germinar previamente em câmara de germinação tipo B.O.D. a $25{ }^{\circ} \mathrm{C}$ e fotoperíodo de 12 horas. Após emissão da radícula as sementes foram acondicionadas nas tampas perfuradas dos potes, que por sua vez serviram como suporte para as plântulas. Em cada pote plástico foi adicionado $750 \mathrm{ml}$ de água destilada com um sistema para oxigenação constante. Foi colocada uma semente para cada pote plástico, totalizando 10 potes, conforme Figura 5. As plantas foram mantidas em sala de crescimento com fotoperíodo de 12 horas e temperatura média de $25^{\circ} \mathrm{C}$. Após 42 dias, a solução contendo os exsudados radiculares de todos os potes foram congelados e liofilizados (Liofilizador de bancada Terroni Enterprize) para obtenção dos produtos liberados pelas raízes. Foi realizada a medida da parte aérea e parte radicular das plântulas e após secas em estufa a $60^{\circ} \mathrm{C}$ por 48 horas e então pesadas para obtenção da biomassa seca das plântulas de G. bonduc.

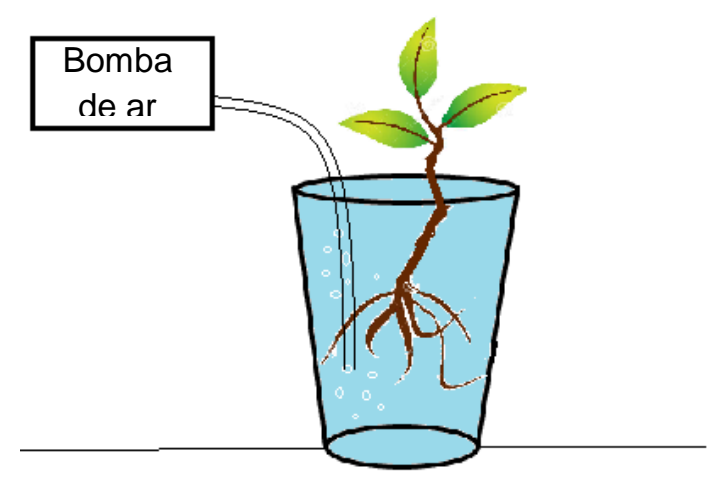

Figura 5. Sistema de hidroponia com sistema de oxigenação constante para coleta dos exsudados radiculares de Guilandina bonduc.

\subsection{Estimativa da concentração dos exsudados liberados em campo}

A estimativa da liberação de exsudado de raiz de $G$. bonduc em condições de campo foram feitas a partir da comparação da quantidade de exsudado da raiz em condições de laboratório (conforme item 3.1 acima) e a biomassa radicular produzida no campo. Para calcular a biomassa total das plantas de $G$. bonduc, cinco halos foram escolhidos aleatoriamente em 
diferentes pontos da llha de Trindade. Em cada halo foram demarcados dois quadrantes de $1 \mathrm{~m}^{2}$ cada (Figura 6). Toda a parte aérea foi retirada para determinar a biomassa da mesma, e para determinar a biomassa radicular 0 solo foi escavado em uma profundidade de $15 \mathrm{~cm}$, não sendo necessário ser mais profundo pois a maior parte das raízes estão localizadas nessa região.

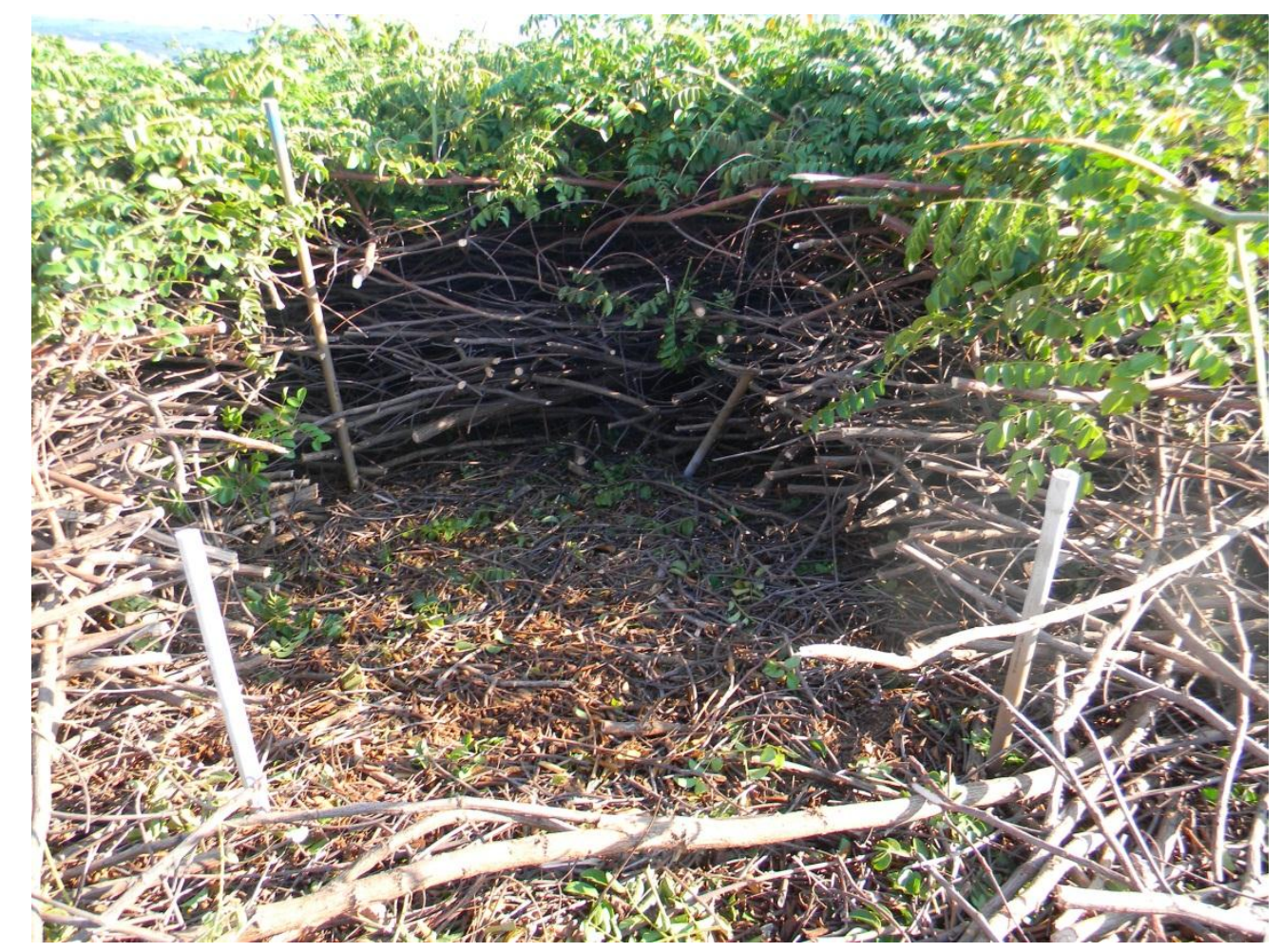

Figura 6. Área de $1 \mathrm{~m}^{2}$ demarcada para obtenção da biomassa da parte aérea e radicular de Guilandina bonduc em população de ocorrência natural na llha de Trindade.

Em campo, com auxílio de balança digital portátil, a massa fresca das raízes, dos ramos e folhas foi mensurada. Posteriormente esse material foi levado para o laboratório de Termobiologia, onde foram colocadas em estufa por $48 \mathrm{~h} / 50^{\circ} \mathrm{C}$, e posteriormente mensurada a massa seca e o teor de água dos tecidos foi verificado. Solo também foi coletado para determinar a capacidade de campo.

Após obter a biomassa das plantas em condições de campo e um paralelo obtido com os resultados de laboratório, pode-se estimar a concentração possível de exsudados liberados no solo em campo para cada um dos halos analisados. Para esse cálculo, fez-se a relação entre a biomassa média de raízes produzidas em condições de laboratório e a sua produção de 
exsudados conforme. A capacidade de campo do solo da liha também foi analisado e está em torno de $50 \%$, ou seja, com o volume de $0,15 \mathrm{~m}^{3}$ $(1 \times 1 \times 0,15 \mathrm{~m})$ de solo, era retido $0,075 \mathrm{~m}^{3}$ de água. Sendo assim, para cada biomassa de raiz presente no campo, foi possível fazer uma estimativa da concentração de exsudados que poderá ser liberado no solo pelas raízes.Para realizar o cálculo da estimativa da concentração dos exsudados liberados em campo foi utilizado a seguinte formula:

$$
\mathrm{ECE}=\left(\frac{\mathrm{BPRC} \times \mathrm{MEL}}{M B P R L}\right) / \mathrm{VA}
$$

Onde:

ECE - Estimativa da concentração dos exsudados produzidos

BPRC - Biomassa da parte radicular em campo

MEL - Média Exsudados produzidos em laboratório

MBPRL - Média da biomassa da parte radicular cultivado em laboratório

VA -Volume de água da solo

\subsection{Preparo dos extratos}

\subsubsection{Extrato aquoso}

As raízes foram secas e trituradas e submetidas à extração aquosa. Para a extração foram usadas $100 \mathrm{~g}$ de raiz para $1000 \mathrm{~mL}$ de água destilada $(10 \%$ p/v). A extração foi realizada com o auxílio de aparelho ultra-sônico SoniClean durante 25 minutos (Wang et al., 2011). Os extratos foram filtrados a vácuo em funil de Büchner com papel filtro. O procedimento de extração foi repetido por 3 vezes com o mesmo material, e realizadas 3 repetições. Após obtenção dos extratos filtrados, os mesmos foram congelados e então liofilizados (Liofilizador de bancada Terroni Enterprize). 


\subsubsection{Extrato metanólico}

Para a extração foram utilizados $50 \mathrm{~g}$ de raiz triturada e $500 \mathrm{~mL}$ de Metanol (J.T. Baker). A extração seguiu a mesma metodologia para a extração aquosa. O extrato obtido foi filtrado a vácuo em funil de Büchner, usando papel de filtro e em seguida foi seco em evaporador rotativo (Marconi - MA-120)

\subsection{Bioensaios}

\subsubsection{Exsudado de raiz}

$O$ exsudado de 5 plantas de $G$. Bonduc obtidas através do experimento descrito no item 3.1, foram selecionados aleatoriamente, do meio hidropônico de crescimento, onde foi coletada e realizado o bioensaio. Utilizaram-se placas de Petri com 5,5 cm de diâmetro, forradas com papel filtro onde foram aplicadas $1,5 \mathrm{~mL}$ de cada solução. As soluções foram utilizadas em bioensaios de crescimento inicial. Foram utilizadas 10 sementes por replicata (placa), e 4 replicatas por tratamento. Após a colocação das sementes nas placas, as mesmas foram fechadas com Parafilm $\AA$. As espécies-alvo utilizadas foram o alface (Lactuca sativa) (Marca Sakata, variedade crespra Lote: 83.245; Germinabilidade 99,9\%) e rabanete (Raphanus sativus) ( Marca Sakata, variedade Crunchy Royale Lote: 94.319; Germinabilidade: 99,9\%) obtida comercialmente. As placas foram mantidas em câmara de germinação a $25^{\circ} \mathrm{C}$ por 4 dias para rabanete e 5 dias para alface.

Passados os 4 e 5 dias de crescimento de rabanete e alface respectivamente, as plântulas tiveram as partes aéreas e radiculares mensuradas com auxílio do programa Image $\mathrm{J} \circledast$ e com tais valores foi calculada a porcentagem de inibição em relação ao controle positivo (água destilada).

Para o cálculo de porcentagem de inibição do crescimento inicial utilizouse a fórmula:

$\%$ inibição $=(X T$ * 100/ XC) -100 
Onde XT é a média de crescimento das plântulas tratadas e XC a média de crescimento das plântulas controle.

Para o cálculo da concentração dos exsudados 3 alíquotas de $10 \mathrm{~mL}$ foram retiradas de cada pote e então liofilizados. Sabendo-se que $1 \mathrm{ppm}$ é igual a $1 \mu \mathrm{g} / \mathrm{mL}$, foi possível calcular qual a concentração do exsudado a partir do pó obtido a partir da liofilização.

\subsubsection{Extrato aquoso da raiz}

O material obtido da liofilização do extrato aquoso foi ressuspenso em água destilada nas concentrações de 2000, 1000, 500, 250 e 125 ppm. As soluções foram utilizadas em bioensaios de crescimento inicial conforme metodologia descrita no item 3.4.1.

\subsubsection{Extrato metanólico de raiz}

Os extratos metanólicos foram ressuspensos em metanol nas concentrações 2000, 1000, 500, 250 e 125 ppm. Utilizaram-se placas de Petri com $5,5 \mathrm{~cm}$ de diâmetro, forradas com papel filtro onde foram aplicadas $1,5 \mathrm{~mL}$ de cada solução. As placas foram colocadas em estufa a $35^{\circ} \mathrm{C}$ para evaporação total do solvente, então foi adicionada água destilada em quantidade que se mantivesse a concentração estipulada. As soluções foram utilizadas em bioensaios de crescimento inicial conforme metodologia descrita no item 3.4.1.

\subsubsection{Bioensaio com solo da ilha}

\subsubsection{Coleta de Solo}

Solo da llha de Trindade foi coletado em 3 pontos de diferentes halos (Coordenadas: $20^{\circ} 31^{\prime} 05,7^{\prime \prime} \mathrm{S} / 29^{\circ} 18^{\prime} 07,5^{\prime \prime} \mathrm{W} ; \quad 20^{\circ} 51,6{ }^{\prime} 31,5^{\prime \prime} \mathrm{S} / 29^{\circ} 30,9^{\prime} 29,9^{\prime \prime} \mathrm{W}$; $20^{\circ} 31^{\prime} 13,2^{\prime \prime S} / 29^{\circ} 186,7$ 'W) e em 3 pontos por halo. Foi coletado solo de dentro da população de $G$. bonduc (solo 1), no solo descoberto, na formação do halo 
(solo 2), e dentro da população de C. atlanticus (solo 3) (Figura 7), obtendo-se assim solos submetidos a três condições diferentes. As amostras de solo foram coletadas na profundidade de $10 \mathrm{~cm}$ a partir da superfície e peneiradas em malha de aço. Cada solo foi homogeneizado após a coleta, e as amostras foram armazenadas por, no máximo 30 dias a $\pm 4{ }^{\circ} \mathrm{C}$ para manutenção da microbiota e então utilizado como substrato nos recipientes de crescimento.

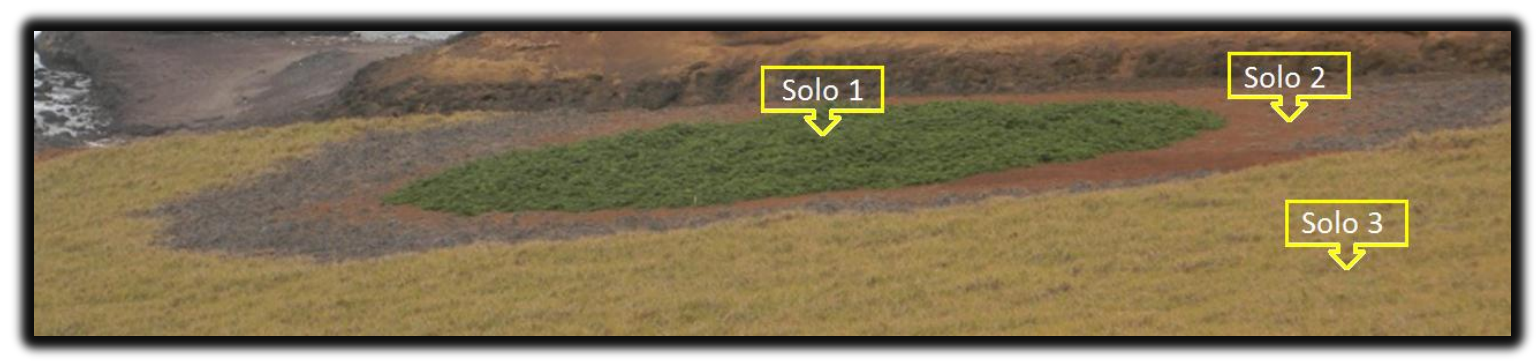

Figura 7. Pontos de coleta dos solos da llha de Trindade utilizados no bioensaio. Solo 1 - População de Guilandina bonduc; Solo 2- Solo descoberto; Solo 3 População de Cyperus atlanticus.

\subsubsection{Bioensaio influência do extrato aquoso e microbiota do solo}

Para testar o efeito do extrato aquoso (item 3.3.1) da raiz de G. bonduc no crescimento inicial de alface e rabanete foi utilizado o solo coletado na população de $C$. atlanticus. Para o experimento com inativação da microbiota, o solo foi autoclavado em três ciclos de $120^{\circ} \mathrm{C}$ por 30 minutos (Trevors, 1996). Foram utilizados então, solo autoclavado (sem a presença de microbiota) e solo não autoclavado (com a presença da microbiota). Foram utilizadas 5 diferentes concentrações do extrato aquoso de raiz: 2000, 1000, 500, 250 e 125 ppm e água como controle.

Foram utilizadas bandejas de células com formato cônico com $6 \mathrm{~cm}$ de altura sendo o diâmetro superior célula (boca) de $3,7 \mathrm{~cm}$, diâmetro inferior célula (fundo) de $1,1 \mathrm{~cm}$, e um furo de $8 \mathrm{~mm}$ por célula. Em cada célula com capacidade de $40 \mathrm{~g}$ de solo, foi adicionado um volume do extrato correspondente a $75 \%$ da capacidade de campo $(15 \mathrm{~mL})$. Em cada recipiente, foram adicionadas uma semente pré-germinada das espécies alvo (Lactuca sativa e Raphanus sativus) (Figura 8). 


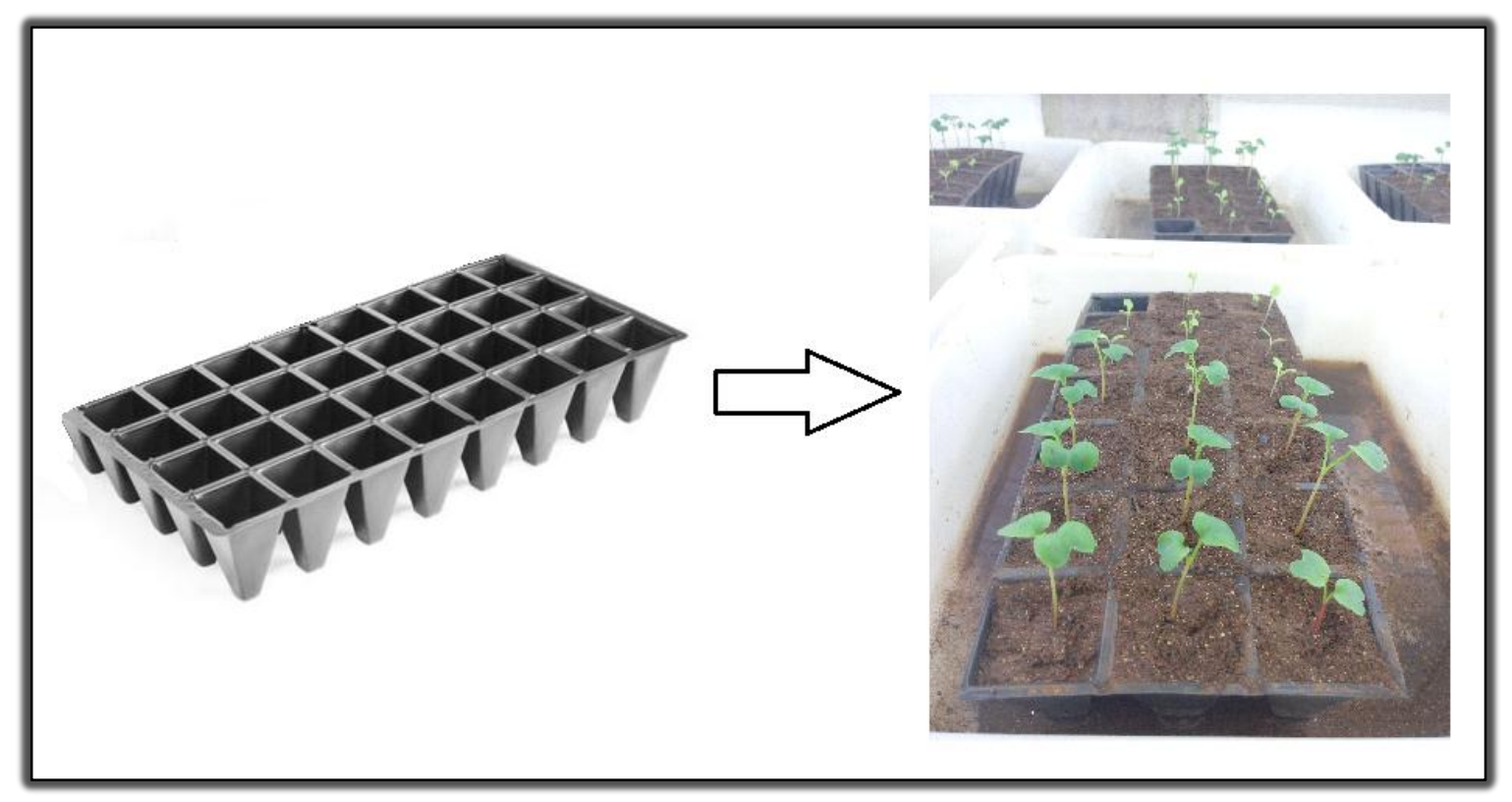

Figura 8. Bandejas de células para crescimento das plântulas em bioensaio com solo

\subsubsection{Bioensaio tipos de solo}

A fim de avaliar os efeitos de possíveis compostos químicos presentes em amostras de solos coletados o solo coletado de dentro da população de $G$. bonduc (solo 1), no solo descoberto, na formação do halo(solo 2), e dentro da população de $C$. atlanticus (solo 3 ) foi utilizado no bioensaio. Os solos foram irrigados com água $(15 \mathrm{~mL})$, podendo assim testar a atividade do solo nas espécies alvo.

Para os bioensaios descritos no item 3.4.4.2 e 3.4.4.3, foram realizadas 10 réplicas para cada tratamento, onde cada repetição era uma plântula em cada célula da bandeja de crescimento (Figura 8). As bandejas com as plântulas foram mantidas em sala de crescimento com temperatura média diária de $25^{\circ} \mathrm{C}$ e fotoperíodo de 12 horas. As bandejas receberam irrigação diariamente, mantendo-se sempre a umidade do solo à capacidade de campo.

Após 5 dias para rabanete e 7 dias para alface as plântulas foram retiradas das células das bandejas e lavadas para a retirada do solo, e então medida a parte aérea e radicular das plântulas. 


\subsection{Isolamento e purificação das substâncias}

\subsubsection{HPLC}

Para comparação dos extratos aquoso, metanólico e exsudados radiculares de G. bonduc foi utilizado o sistema de HPLC LaChrom Elite (Hitachi, Tokyo, Japan), equipado com bomba L2130, amostrador automático; L2200, forno da coluna (L2300) a $25^{\circ} \mathrm{C}$ e detector DAD L2455 (Hitachi, Tokyo, Japan). A separação foi realizada utilizando coluna de fase reversa C18 (Purospher Star $5 \mu \mathrm{m}, 150 \mathrm{~mm}$ X4,6 mm) em combinação com pré-coluna (4X4;de partícula tamanho $5 \mu \mathrm{m}$ - Merck-Germany). Os eluentes utilizados foram: Solução aquosa de ácido fosfórico (1\%) (Solvente A) e acetonitrila (solvente B). O gradiente utilizado foi de $90 \%$ do solvente $\mathrm{A}$ e $10 \%$ do solvente B durante $0 \mathrm{~min}, 70 \%$ de $A$ e a $30 \%$ de $B$ durante $40 \mathrm{~min}, 50 \%$ de $A$ e $50 \%$ de B durante $50 \mathrm{~min}, 90 \%$ de $A$ e $10 \%$ de B durante 55 min com um fluxo de $0,6 \mathrm{~mL}$ por minuto. A aquisição de dados foi realizada através do software EZChrom Elite (versão 3.3.2 SP1 - Scientific Software Inc.). As substâncias presentes nas amostras foram comparados com a biblioteca existente de padrões comerciais (ChromaDex®), e entre as amostras de acordo com seus espectros de UV-Vis e tempos de retenção.

\subsubsection{Cromatografia líquida em coluna}

Primeiramente foi realizado o fracionamento líquido-líquido do extrato metanólico da raiz de G. bonduc. Foram utilizados 5 gramas de extrato seco, e esse foi dissolvido em $200 \mathrm{~mL}$ de água e colocado em um funil de separação de $1000 \mathrm{~mL}$. Em seguida foram adicionados $200 \mathrm{~mL}$ de acetato de etila que foi levemente agitado para evitar a formação de emulsões durante o processo de fracionamento. A mistura foi deixada em um suporte para separação das fases, e então o solvente orgânico foi retirado e reservado. Essa operação foi repetida por 5 vezes, onde o critério utilizado para o número de repetições do processo de fracionamento se deu até que solvente adicionado ao extrato saísse límpido. Após esse procedimento, o solvente foi removido da fração através da evaporação com o auxílio de um rotavapor.

Após o fracionamento líquido-líquido, a fração obtida do extrato metanólico foi subfracionado por cromatografia em coluna de sílica gel $(60 \mathrm{~cm}$ 
altura e $3 \mathrm{~cm}$ de diâmetro). Foram utilizados os eluentes hexano:acetato de etila em ordem crescente de polaridade (0 a 100\%). A quantidade de solvente aplicado foi determinada pela capacidade de arraste em cada concentração. Foram coletadas subfrações que posteriormente foram agrupadas com base na cromatografia em camada delgada (CCD) de acordo com a semelhança e pureza dos componentes revelados. A cromatografia por camada delgada foi realizada em placas (Alugram Sil G/ UV254) de tamanho $4 \times 5 \mathrm{~cm}$, com eluente acetato de etila: hexano, reveladas com Oleum (ácido sulfúrico, água e ácido acético, na proporção 1:4:20) e queimadas a aproximadamente 150 C.

O composto isolado foi agrupado e seco em evaporador rotativo e então

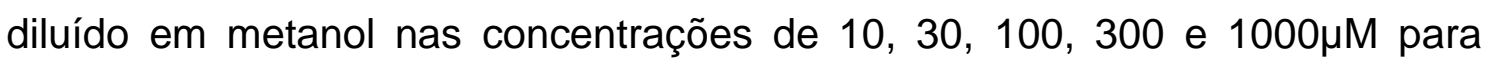
testar a sua atividade em bioensaio conforme descrito no item 3.4.3.

\subsubsection{Identificação do produto por Ressonância Magnética Nuclear}

A partir da separação através da cromatografia de coluna foi possível isolar uma substância. Para a identificação deste produto, $20 \mathrm{mg}$ da amostra foi solubilizada em clorofórmio deuterado, e então foi submetida a análise de Ressonância Magnética Nucelar (RMN). Os espectros de Ressonância Magnética Nuclear de hidrogênio ( $R M N$ de $\left.{ }^{1} \mathrm{H}\right)$ e de carbono (RMN de ${ }^{13} \mathrm{C}$ ) foram adquiridos no aparelho Varian Mercury Plus $300 \mathrm{MHz}, 7,05 \mathrm{~T}$. Deslocamentos químicos $(\delta)$ foram reportados em partes por milhão $(\mathrm{ppm})$, tendo como referência interna o tetrametilsilano $\left(0,00 \mathrm{ppm}\right.$ para o $\left.\mathrm{RMN}{ }^{1} \mathrm{H}\right)$ e o clorofórmio deuterado (7,26 ppm para o RMN $1 \mathrm{H}$ e 77,0 ppm para $\left.0^{13} \mathrm{C}\right)$.

$O$ assinalamento dos hidrogênios e carbonos foi confirmado por experimentos uni e bidimensionais (COSY, DEPT e HMQC).

\subsection{Análise estatística}

Para a análise da inibição ou estímulo causado nas partes aéreas e radiculares das espécies-alvo em relação ao controle, as análises estatísticas foram baseadas em testes paramétricos. Os dados foram submetidos a análise de normalidade e transformados quando necessário para atingir a normalidade. Os dados foram submetidos à análise da variância (ANOVA) comparando-se as médias usando o teste de Tukey a $5 \%$ de significância. As análises foram 
realizadas utilizando o software SPSS®) (Statistical Package for the Social Sciences).

Os resultados são apresentados como diferenças percentuais em relação ao controle. Zero representa o controle, os valores positivos representam o estímulo de crescimento e valores negativos representam inibição do crescimento das espécies alvo.

\section{Resultados e discussão}

\subsection{Exsudados radiculares}

Para análise dos exsudados radiculares das plantas de $G$. bonduc cultivadas em laboratório, primeiramente uma alíquota foi utilizada para determinar a concentração obtida através do meio hidropônico. De acordo com Tabela 2 pode-se observar que a concentração de substâncias exsudadas no período de 42 dias variou de 9,5 a 70 ppm.

Tabela 2. Concentração dos exsudados radiculares de Guilandina bonduc liberados no período de 42 dias em meio hidropônico $(750 \mathrm{~mL})$, comprimento da parte aérea (PA) e radicular (PR) (em centímetros) e biomassa seca da parte aérea (PA), radicular (PR) e cotilédones das plantas cultivadas.

\begin{tabular}{lccccccc} 
Repetição & $\begin{array}{c}\text { Concentração } \\
(\mathrm{ppm})\end{array}$ & $\begin{array}{c}\text { Comprimento } \\
\mathrm{PA}(\mathrm{cm})\end{array}$ & $\begin{array}{c}\text { Comprimento } \\
\mathrm{PR}(\mathrm{cm})\end{array}$ & $\begin{array}{c}\text { Biomassa } \\
(\mathrm{PA})(\mathrm{g})\end{array}$ & $\begin{array}{c}\text { Biomassa } \\
(\mathrm{PR})(\mathrm{g})\end{array}$ & $\begin{array}{c}\text { Biomassa } \\
\text { cotilédones }(\mathrm{g})\end{array}$ & $\begin{array}{c}\text { Biomassa } \\
\text { total }(\mathrm{g})\end{array}$ \\
\hline $\mathrm{R} 1$ & 19 & 9,20 & 2,74 & 0,3429 & 0,0895 & 0,7343 & 1,1667 \\
$\mathrm{R} 2$ & 9,5 & 7,30 & 9,64 & 0,2408 & 0,0900 & 0,9880 & 1,3188 \\
$\mathrm{R} 3$ & 9,5 & 6,96 & 7,12 & 0,403 & 0,1015 & 0,7893 & 1,2938 \\
$\mathrm{R} 4$ & 28,5 & 7,29 & 4,78 & 0,3143 & 0,1027 & 0,8255 & 1,2425 \\
R5 & 70,0 & 8,55 & 2,82 & 0,3093 & 0,0710 & 0,7399 & 1,1202 \\
Média & 27,3 & 7,86 & 5,42 & 0,3220 & 0,0909 & 0,8154 & 1,2284 \\
Desvio & 25,14 & 0,96 & 2,96 & 0,0588 & 0,0128 & 0,1035 & 0,0839 \\
padrão & $2,9,056$ &
\end{tabular}

Pode-se observar que houve uma correlação negativa entre a produção de exsudados pela planta em relação a sua biomassa total (Figura 9). Foram avaliadas também, as correlações entre a produção de esxudados e a parte aérea e radicular e todas apresentaram correlações negativas. 


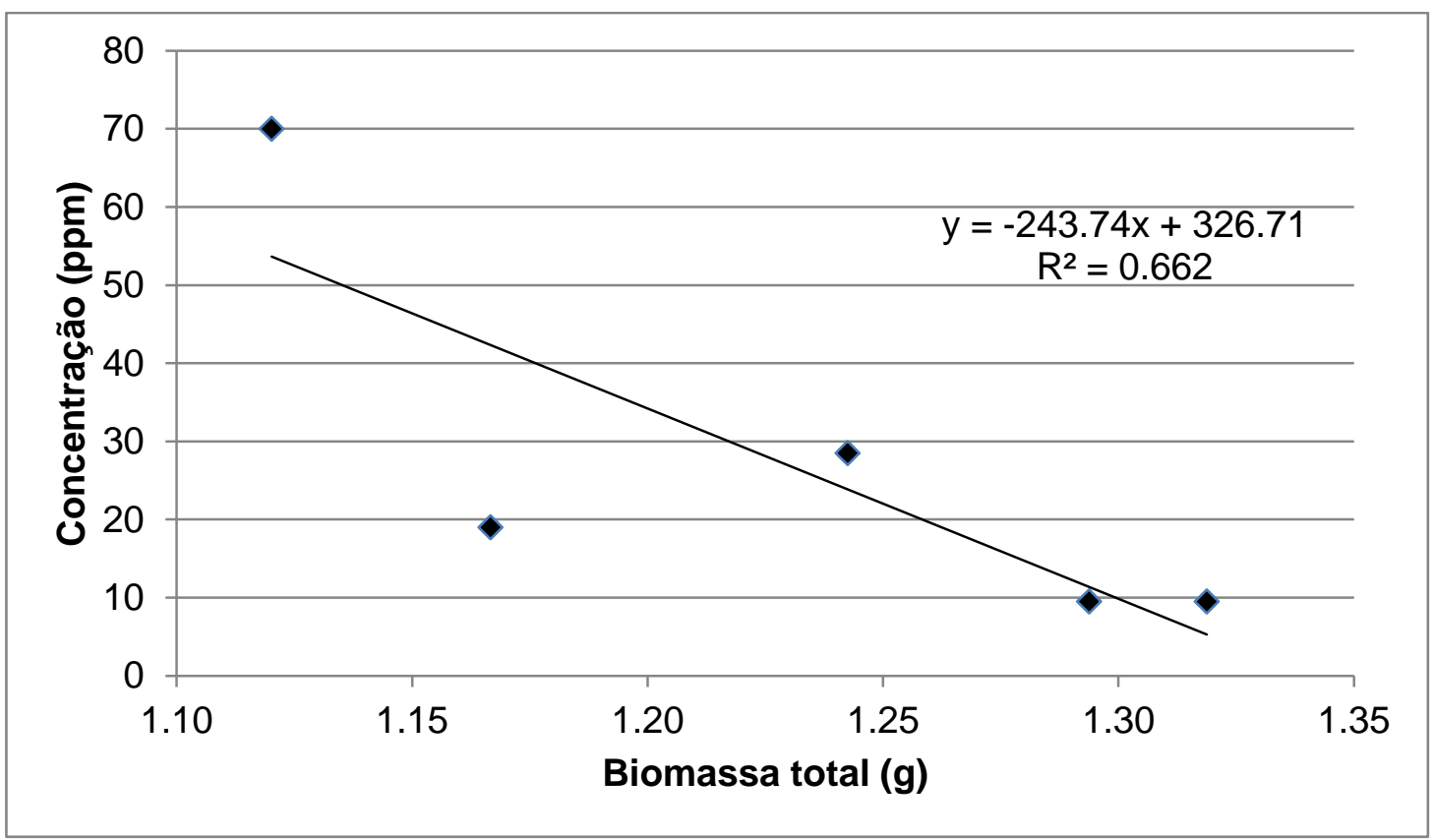

Figura 9. Correlação da produção de exsudados radiculares em relação a biomassa total da planta de Guilandina bonduc cultivadas em meio hidropônico durante 42 dias

As plantas realizam a fotossíntese para poder converter energia luminosa em energia química na forma de carboidratos, e estes, em seguida, são alocados para o crescimento e desenvolvimento, ou investido em defesas para a planta, onde esse investimento vai depender da situação em que as plantas se encontram (Huot et al., 2014). A produção de produtos químicos para defesa é acompanhado por um custo de materiais ou energia, resultando em uma taxa de crescimento mais lento (Gulmon e Mooney, 1986).

Trade-offs - ou correlações negativas - entre as taxas de crescimento e de investimento em defesa foi previsto pela teoria do ciclo de vida, porque defesa pode apresentar um alto custo para as plantas (Bazzaz, et al., 1987, Iwasa, 2000). Uma planta que não investe em defesa pode crescer mais rapidamente, mas quando é atacada por herbívoros, por exemplo, sofre mais danos. Por outro lado, se uma planta investe em metabólitos de defesa, consequentemente deve crescer mais lentamente, mas sofre menos danos quando está sob ameaça (Paul-Victor et al, 2010).

Em estudos realizados por Züst e colaboradores (2011) também demonstraram que há uma correlação negativa entre as taxas de glucosinolatos e o crescimento de Arabidopsis, onde a planta investiu em produção de compostos para defesas e consequentemente a planta teve a taxa 
de crescimento reduzido. Este estudo suporta a hipótese de que investir em produção de compostos de defesa tem um custo elevado para a planta, interferindo no seu crescimento.

\subsection{Estimativa de produção de exsudados radiculares em campo}

Para estimar a produção de exsudados de raiz em condições de campo, na Tabela 3, encontram-se os dados da biomassa da parte aérea, parte radicular e biomassa total das plantas de G. bonduc, numa área de $1 \mathrm{~m}^{2}$, localizadas na llha de Trindade, onde a partir desses dados foi possível calcular a estimativa da quantidade de substâncias liberadas pelas raízes em condições de campo.

Tabela 3. Biomassa da parte aérea (PA), parte radicular (PR) e biomassa total das amostras $\left(1 \mathrm{~m}^{2}\right)$ de cinco diferentes populações de Guilandina bonduc que formam halos de solo nú localizados em pontos diferentes da llha da Trindade, e estimativa de concentração de exsudados liberados pelas raízes.

\begin{tabular}{lcccc}
\hline & $\begin{array}{c}\text { Biomassa PA } \\
\mathbf{( g )}\end{array}$ & $\begin{array}{c}\text { Biomassa PR } \\
\mathbf{( g )}\end{array}$ & $\begin{array}{c}\text { Biomassa Total } \\
\mathbf{( g )}\end{array}$ & $\begin{array}{c}\text { Estimativa de } \\
\text { concentração } \\
\text { dos exsudados } \\
\text { (ppm) }\end{array}$ \\
\hline Halo 1 & 3181.72 & 500.87 & 3682.59 & 2004.80 \\
\hline Halo 2 & 1109.00 & 234.37 & 1343.37 & 938.08 \\
Halo 3 & 1941.41 & 205.74 & 2147.15 & 823.50 \\
\hline Halo 4 & 1800.31 & 591.09 & 2391.40 & 2365.92 \\
Halo 5 & 2178.75 & 160.74 & 2339.49 & 643.36 \\
\hline Média & 2042.24 & 338.56 & 2380.80 & 1355.13 \\
\hline Desv. Padrão & 751.11 & 193.80 & 840.73 & 775.71 \\
\hline
\end{tabular}

Através dos dados obtidos foi possível observar que as concentrações variaram de 643,36 ppm até 2365,92 ppm. Portanto as concentrações utilizadas nos bioensaio de laboratório condizem com as concentrações que possam estar sendo liberadas em campo.

A estimativa das concentrações dos aleloquímicos liberados para o meio não é simples, pois os mesmos estão sujeitos a diferentes interações que podem ocorrer no meio ambiente (Barto e Cipollini, 2009), como a decomposição dos compostos liberados e a interação com a rizosfera.

As taxas de exsudação também podem variar de acordo com o grau de desenvolvimento da planta e entre genótipos dentro de uma única espécie. As 
mudas das plantas produzem quantidades menores de exsudados radiculares; aumentando a produção gradualmente até a floração e diminuindo novamente na maturidade (Aulakh et al., 2001). Garcia et al. (2001) demonstraram que a exsudação radicular é positivamente correlacionada com o crescimento das raízes; isso significa que os sistemas de raízes que crescem ativamente secretam mais exsudados. Da mesma forma, eles observaram variações nos padrões de exsudação entre genótipos da mesma espécie de plantas. Por exemplo, os ecótipos Arabidopsis thaliana, Col-0 e Ler, diferem nos níveis de malato presentes em seus exsudados radiculares (Hoekenga et al., 2003).

O que se pode concluir é que $G$. bonduc pode liberar exsudados de forma significativa, e esses exsudados podem interferir nas relações plantaplanta no local onde ela ocorre

\subsection{Bioensaio Exsudados radiculares}

$O$ resultado do bioensaio com o exsudado da raiz de $G$. bonduc, cultivada em hidroponia nas condições de laboratório e coletados aleatoriamente (Tabela 2) pode ser visto na Figura 10. O crescimento inicial de alface e rabanete foi afetado pelos exsudados radiculares testados, causando principalmente estímulos consideráveis no tamanho das raízes (Figura $10 \mathrm{~A} \mathrm{e}$ B), em relação ao controle.

No bioensaio utilizando alface como espécie alvo, pode-se notar que nas concentrações de 28,5 e $70 \mathrm{ppm}$ o crescimento radicular foram diferentes estatisticamente do controle sendo que sofreram um estímulo de $42,68 \%$ e 80,71\% respectivamente (Figura 10 A). Já o crescimento do hipocótilo não diferiu estatisticamente do controle em nenhuma das repetições. 


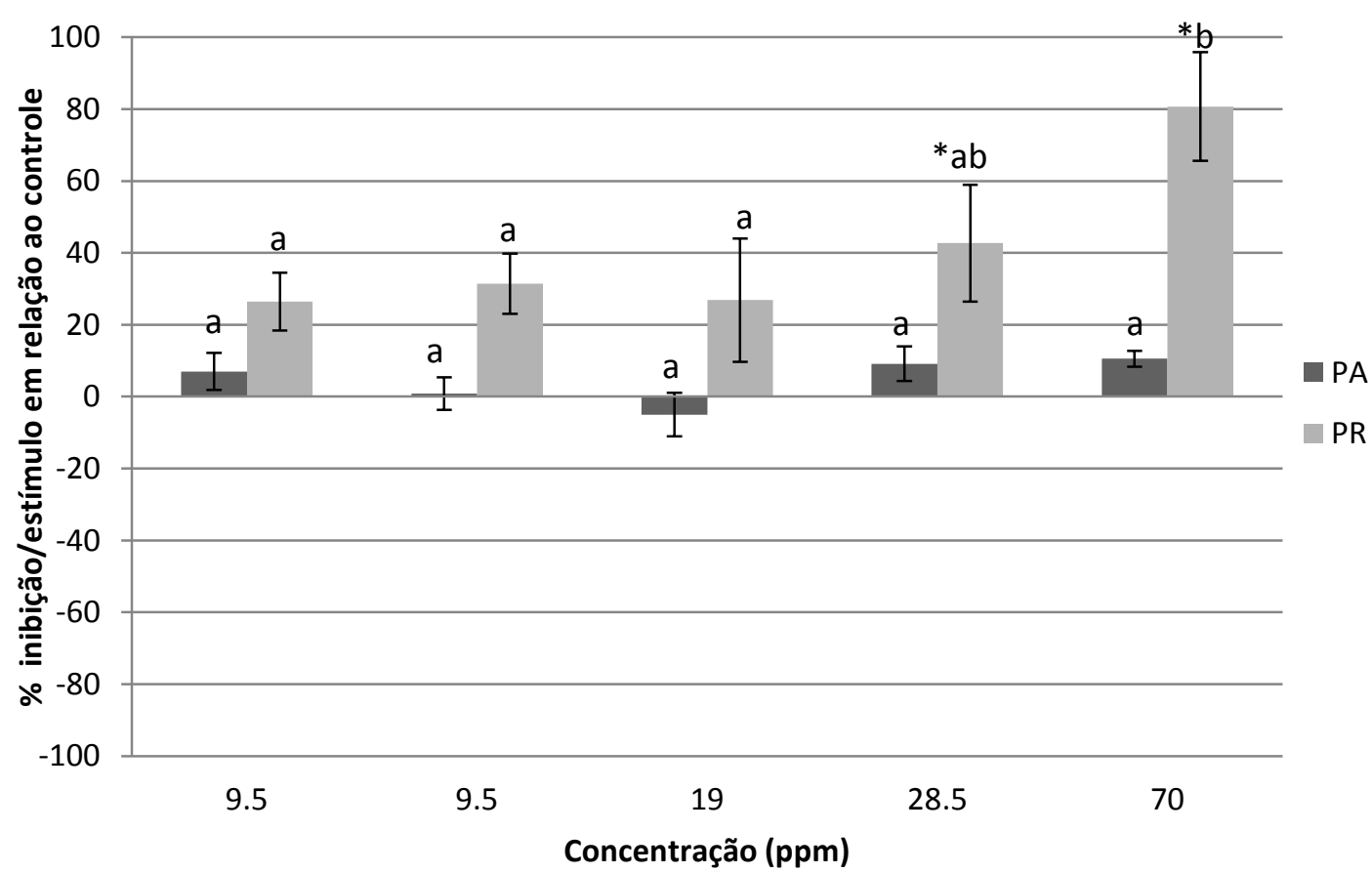

A

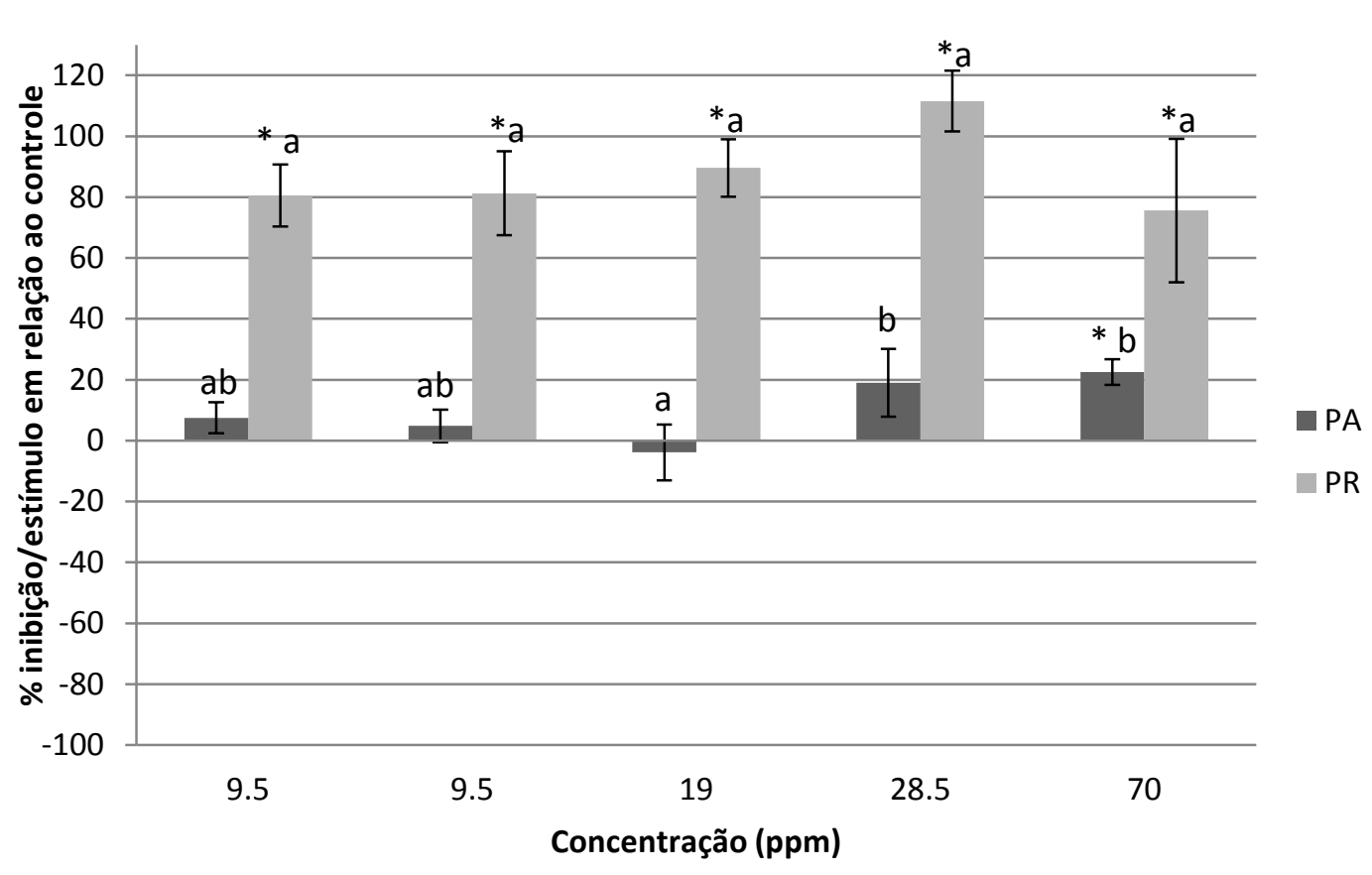

Figura 10. Porcentagem de inibição/estímulo no crescimento inicial da parte aérea (PA) e radicular (PR) das plântulas de alface (Lactuca sativa) (A) e plântulas de rabanete (Raphanus sativus) (B) sob influência dos exsudados radiculares de Guilandina bonduc. Letras diferentes indicam diferença estatística entre os tratamentos $e^{*}$ indica diferença estatística em relação ao controle. $p \leq 0,05$.

No bioensaio utilizando rabanete como espécie alvo, pode-se notar que em todas os tratametos o crescimento radicular foi diferente estatisticamente, sendo que todos tiveram um estímulo maior que 70\% (Figura $10 \mathrm{~B}$ ). Diferente 
de alface, que não houve diferença estatistica em relação ao controle, no crescimento dos hipocótilos das plântulas e entre os tratamentos, para rabanete houve diferença estatistica na concentração de 70 ppm, com um estímulo de $22,56 \%$.

Em geral, as raízes são mais sensíveis às substâncias presentes nos extratos comparativamente às demais estruturas da plântula. Esta ocorrência deve-se ao fato das raízes estarem em contato mais direto e prolongado com o extrato e aos aleloquímicos, em relação às demais estruturas da plântula (Belel \& Rahimatu, 2012; Chon et al.; 2000, Chung et al. 2001; Zahedi \& Ansari, 2011).

Reigosa et al. (1999) relataram que os efeitos dos aleloquímicos nos diferentes processos fisiológicos de uma planta são dependentes da concentração, ou ao menos se espera que sejam, promovendo ativações em baixas concentrações e inibições em altas concentrações, sendo que podemos perceber esse resultado nesse trabalho, já que os extratos utilizados possuem baixas concentrações. Esse fenomeno é conhecido por hormesis sendo um fenômeno de dose-resposta que se caracteriza por uma estimulação em doses baixas e de inibição em doses elevadas (Calabrese \& Blain, 2011).

$O$ estímulo no crescimento de plântulas vem sendo rotineiramente descrito em trabalhos relacionados à alelopatia e possivelmente, este processo esteja relacionado à influência do extrato sobre a produção fitormonal da espécie alvo ou aumento na sensibilidade de seus tecidos (Borella et al., 2012; Rice 1984).

Estímulo de crescimento das espécies alvo sob influência de exsudados radiculares é já foi relatado na literatura, como por exemplo, o trabalho realizado por Zhang e Fu (2010), onde os exsudados radiculares das plantas jovens de Eucalyptus citriodora e Eucalyptus camaldulensis exerceram efeitos estimulatórios sobre a radícula de rabanete e feijão, nas menores concentrações e, em concentrações altas, exerceram efeitos tóxicos com redução do comprimento da radícula das plantas testadas.

O que se pode verificar é que os exsudados produzidos por $G$. bonduc durante o período de crescimento em hidroponia causam o estímulo de crescimento das espécies alvo testadas. 


\subsection{Bioensaio extrato aquoso de raiz}

Os bioensaios com extrato aquoso das raízes de G. bonduc podem ser vistos na Figura 11. O crescimento da parte aérea e parte radicular apresentou estímulo quando as plântulas de rabanete cresceram na presença dos extratos aquosos da raiz de $G$. bonduc, sendo que a parte aérea em todas as concentrações diferiram estatisticamente do controle, porém a parte radicular apresentou estímulo do crescimento mas somente nas concentrações mais altas de 500 ppm, 1000 ppm e 2000 ppm que diferiram estatisticamente do controle (Figura $11 \mathrm{~A})$. 

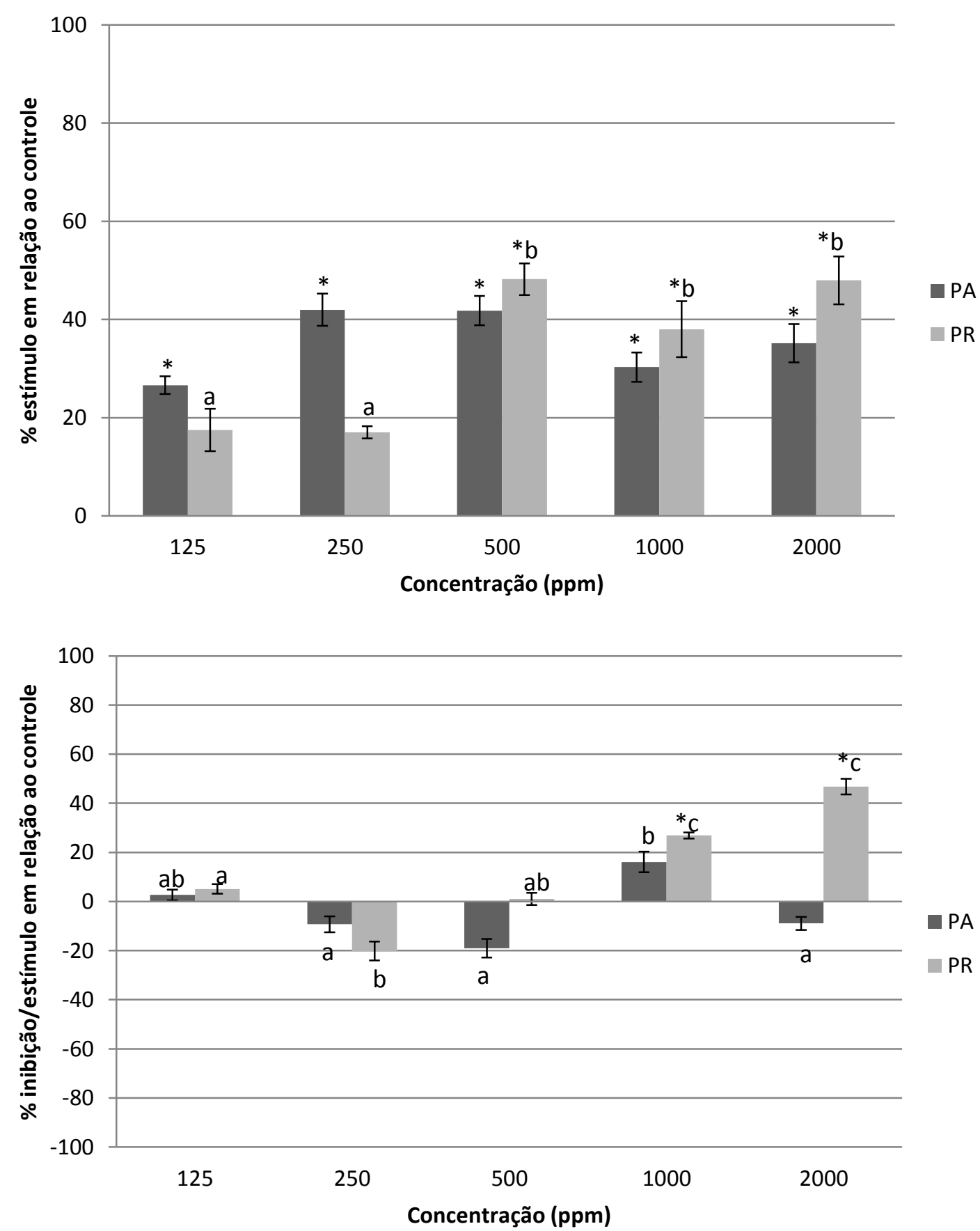

B

Figura 11. Porcentagem de inibição/estímulo no crescimento inicial da parte aérea (PA) e radicular (PR) das plântulas de rabanete (Raphanus sativus) (A) e plântulas de alface (Lactuca sativa) (B sob influência de extrato aquoso radicular de Guilandina bonduc. Letras diferentes indicam diferença estatística entre os tratamentos $e^{*}$ indica diferença estatística em relação ao controle. $p \leq 0,05$

No bioensaio utilizando alface como espécie alvo também se observou estímulo de crescimento em relação ao controle e o maior estímulo ocorreu na 
parte radicular nas concentrações de 1000 ppm (26,87\%) e 2000 ppm $(46,81 \%)$, sendo que a parte aérea também teve estímulo de crescimento nas concentrações 125 ppm (2,66\%) e 1000 ppm (16,09\%), mas não diferiu estatisticamente do controle. Nas demais concentrações houve inibição do crescimento da parte aérea das plântulas, mas não houve diferença estatística em relação ao controle (Figura 11B).

Segundo Rice (1984), estímulos e inibições no desenvolvimento das plantas na presença de extratos de outras plantas são comumente encontrados quando se trabalha com substâncias alelopáticas. Este fato se deve à concentração na qual estas substâncias se encontram, pois estas podem estimular ou inibir o crescimento das plantas em concentrações apropriadas. Este fato pode ser observado quando o extrato não afetou significativamente 0 crescimento da parte aérea em 125, 250 e 500 ppm ppm e estimulou em torno de $26 \%$ em 1000ppm e 46\% em 2000ppm (Figura 12A e B).

Carpanezzi \& Gualtieri (2014) também obtiveram esse efeito em relação a dose quando testado os efeitos do extrato de Pittosporum undulatum Vent. sobre a germinação e crescimento inicial de Echinoclhoa crus-galli (L.) P. Beauv.

Como também foi observado para o exsudado radicular, o extrato aquoso das raízes de G. bonduc, nas concentrações utilizadas no bioensaio, também estimulam crescimento das espécies alvo. Outros trabalhos também identificaram estímulo no crescimento das plantas alvo na presença de extratos, como por exemplo, o uso de extrato de Euphorbia serpens Kunth que estimulou a parte aérea e radicular de Lactuca sativa (Dana \& Domingo, 2006) e extratos de Phytolacca americana L. também estimulou o crescimento da parte aérea e radicular de Cassia mimosoides L.(Kim et al. 2005).

\subsection{Bioensaio extrato metanólico}

O extrato metanólico da raiz de $G$. bonduc provocou uma redução no crescimento da radícula de plântulas de alface, sendo os efeitos inibitórios crescentes com o aumento da concentração dos extratos utilizados. As concentrações de 500, 1000 e 2000 ppm apresentaram um efeito inibitório estatisticamente significativo em relação ao controle. A resposta de crescimento do hipocótilo de alface variou de acordo com as concentrações do 
extrato, mas também apresentaram inibição do crescimento em todas as concentrações testadas (Figura $12 \mathrm{~B}$ ).

A resposta de crescimento da parte aérea das plântulas de rabanete também foi dose-dependente, onde a porcentagem de inibição foi crescente, conforme aumentava a concentração do extrato. Apesar de apresentar inibição de crescimento em quase todas as concentrações testadas, apenas em 2000ppm apresentou efeito estatisticamente significativo em relação ao controle, tanto da parte aérea quanto da parte radicular da espécie alvo (Figura 12 A). 

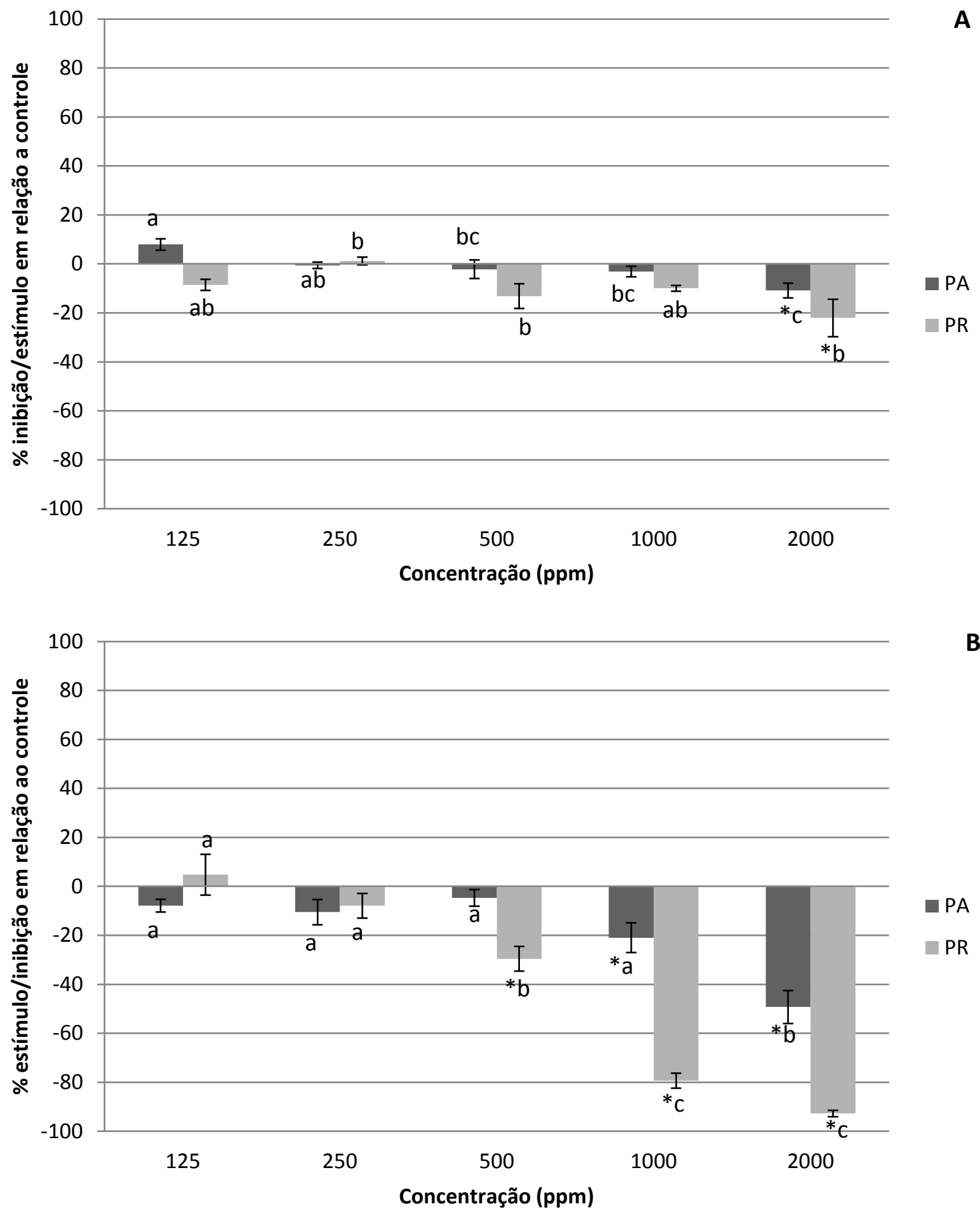

Figura 12. Porcentagem de inibição/estímulo no crescimento inicial da parte aérea (PA) e radicular (PR) das plântulas de rabanete (Raphanus sativus) (A) e plântulas de alface (Lactuca sativa) (B) sob influência de extrato metanólico radicular de Guilandina bonduc. Letras diferentes indicam diferença estatística entre os tratamentos $e^{*}$ indica diferença estatística em relação ao controle. $p \leq 0,05$

Novamente o efeito mais pronunciado foi nas raízes das espécies alvo. Abdelgaleil e Hashinaga (2007) também encontraram efeitos mais pronunciados no crescimento radicular das espécies alvo (alface, rabanete, 
cebola, e trigo) quando crescidas sob influência de compostos extraídos a partir do extrato de Magnolia grandiflora.

Souza Filho \& Duarte (2007) afirmam que as inibições produzidas no desenvolvimento da raiz são um dos principais fatores que indicam sensibilidade da planta aos efeitos das fitotoxinas alelopáticas. Correia e colaboradores (2005) afirmam que em experimentos em placas de Petri, o efeito nas raízes ocorre com mais frequência em comparação com a parte aérea, pois a absorção dos aleloquímicos pelas raízes são favorecidos pelo contato físico com o papel filtro. Além disso, as superfícies das raízes primárias são mais permeáveis a fitotoxinas em comparação às superfícies dos hipocótilos, devido a presença de uma camada de cutícula protetora menos pronunciada sobre a raiz primária, o que pode resultar numa maior penetração e concentração destes compostos dentro dos tecidos da raiz (Yoshimura et al., 2011).

As substâncias alelopáticas quando em contato com a raiz, podem influenciar diretamente no seu crescimento, pois interferem na divisão celular, na permeabilidade das membranas, e na atividade de enzimas (Singh et al., 2006; Teerarak et al., 2012).

Os resultados encontrados no bioensaio no qual as espécies alvo cresceram na presença de extrato metanólico diferem quando comparado com os resultados encontrados no crescimento das espécies alvo sob influência do extrato aquoso e exsudados radiculares, sendo que o extrato aquoso e exsudados apresentaram estímulo de crescimento e o extrato metanólico apresenta inibição de crescimento das espécies alvo. Isso pode ser explicado pela diferença dos solventes utilizados para extração, pois segundo Inderjit e Dakshini (1995) existem diferenças qualitativas e quantitativas entre solventes orgânicos e os que ocorrem em condições naturais. Portanto, a diferença dos resultados encontrados, possivelmente se deve a essa diferença na extração e consequentemente a presença dos compostos.

As espécies alvo escolhidas são as mais utilizadas em estudos de fitotoxicidade. As diferentes respostas encontradas para as espécies podem estar relacionadasà características distintas entre elas quanto a morfologia da semente. Em estudos realizados por Pellissier (2013), foram avaliadas as respostas de acordo com a biometria das sementes de duas espécies alvo 
(alface e rabanete) sob influência de aleloquímicos. O primeiro passo consistiu na medição do volume, massa, forma das sementes e área de contato das sementes com o papel filtro na placa de Petri. Os resultados mostraram que rabanete foi mais afetado quando a quantidade de composto era calculado de acordo com os parâmetros biométricos que representava a área de tegumento das sementes diretamente em contato com o papel filtro impregnado BOA na placa de Petri.

Abdelgaleil e Hashinaga (2007) extraíram e isolaram duas lactonas sesquiterpênicas, costunolideo e parthenolideo a partir do extrato de diclorometano de folhas Magnolia grandiflora e testaram o efeito das duais substâncias na germinação e crescimento inicial de alface e rabanete. Os autores relataram que houve uma maior sensibilidade de alface na germinação e crescimento inicial em comparação com rabanete quando ambas as sementes foram expostas a $500 \mu \mathrm{g} / \mathrm{ml}$ de parthenolideo. Estes autores obtiveram resultados opostos com $500 \mu \mathrm{g} / \mathrm{ml}$ de costunolideo, sendo rabanete mais sensível que alface tanto na germinação quanto no crescimento da parte aérea e radicular das espécies. Este efeito pode ser encontrado quando comparamos os efeitos do extrato aquoso com o extrato metanólico onde alface foi mais sensível aos compostos presentes no extrato metanólico e rabanete mais sensível aos compostos presente no extrato aquoso da raiz de G. bonduc.

Abdelgaleil \& Hashinaga (2007) sugerem que o efeito observado depende da química do extrato, bem como as espécies alvo, mas não apontam para biometria das sementes como um possível fator. Já Pellissier (2013) aponta que as características biométricas das sementes é um fator a ser considerado, pois isso pode contribuir para melhorar a comparabilidade das dos resultados de diferentes espécies de plantas suscetíveis aos aleloquímicos, portanto, os resultados encontrados nos bioensaio deste trabalho, onde o mesmo extrato apresenta estímulo de crescimento em uma espécie alvo e inibição na outra espécie alvo pode estar relacionada as características biométricas de cada semente utilizada como espécie alvo nos bioensaios. 


\subsection{Bioensaio em solo}

\subsubsection{Efeito do extrato aquoso no crescimento das espécies alvo}

Em bioensaio realizado com a adição de extrato aquoso das raízes de G. bonduc no solo da ilha, foi possível verificar que o extrato aquoso teve efeito inibitório apenas no crescimento da raiz, na concentração de 250 ppm em ambas espécies alvo (Figura 13 A e B), sendo que para alface (Figura 13 B) a inibição foi de 33,72\% e rabanete teve uma inibição de crescimento de 13 , $83 \%$. Nas outras concentrações testadas, verificou-se que ocorreram estímulos e inibições do crescimento, mas não diferiram estatisticamente do controle, possivelmente tal resposta se deve ao alto desvio padrão encontrado nas médias. 

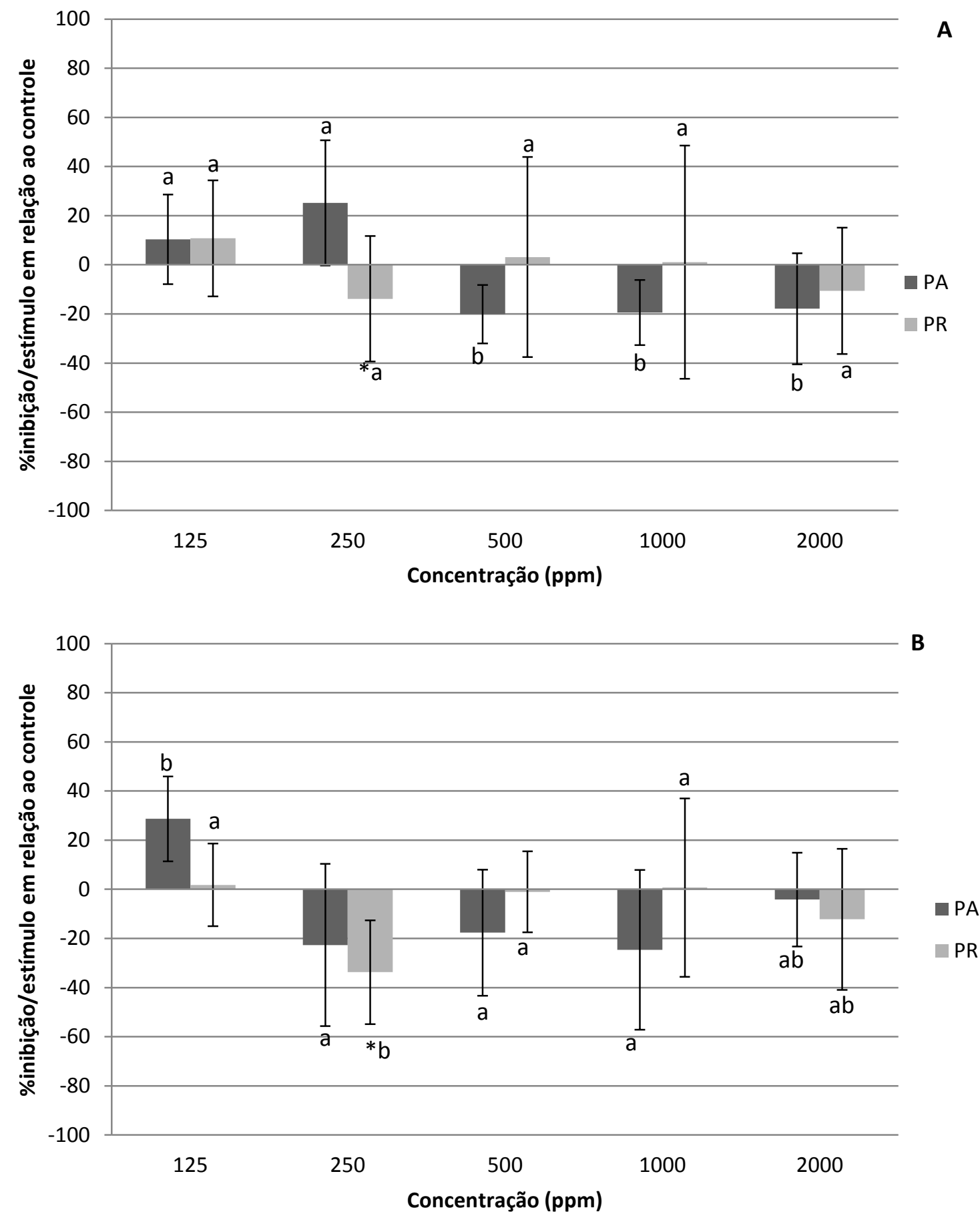

Figura 13. Porcentagem de inibição/estímulo no crescimento inicial em relação ao controle, da parte aérea (PA) e radicular (PR) das plântulas de rabanete (Raphanus sativus) (A) e plântulas de alface (Lactuca sativa) (B), sob influência do extrato metanólico radicular de Guilandina bonduc. Letras diferentes indicam diferença estatística entre os tratamentos $e^{*}$ indica diferença estatística em relação ao controle. $p \leq 0,05$. 
De acordo com essa afirmação, pode-se verificar com esse resultado que quando o extrato aquoso das raízes de $G$. bonduc foi adicionado ao solo, independente da concentração, é diferente ao que foi encontrado utilizando placa de Petri e papel filtro como substrato, sendo que esse ocorreu estímulo de crescimento das espécies alvo.

Em estudos envolvendo interações alelopáticas, o solo ganha particular importância, por tratar-se do substrato em que parte significativa das interações entre as plantas ocorre. (Badri \& Vivanco, 2009; Chen 1992).

Segundo Reigosa e colaboradores (2013) o substrato utilizado em experimentos de fitotoxicidade devem ser representativos do lugar onde as plantas em estudo coexistam, ou pelo menos da região onde elas ocorrem. Experimentos utilizando papel filtro, vermiculita ou outros tipos de substratos, acabam excluindo os efeitos bióticos e abióticos do substrato sobre a bioatividade das substâncias.

A maior parte dos trabalhos, foca no fato de que todas as plantas produzem compostos secundários que, em concentrações suficientemente elevadas são fitotoxicos em bioensaios de laboratório na ausência de solo. Assim pode-se mostrar que qualquer planta pode produzir compostos com capacidade fitotóxica (Duke,2010). Usar substratos artificiais para os bioensaios em vez de utilizar substrato natural acaba se tornando uma desvantagem, pois estes sistemas, portanto, não podem apresentar uma imagem verdadeira da liberação dos aleloquímicos, a adsorção do solo e absorção pelas plantas, sendo esse um complexo sistema de interação rizosfera-aleloquímios-planta (Duke, 2010). Assim, os resultados obtidos a partir de estudos alelopáticos laboratoriais usando papel filtro e os resultados utilizando solo como substrato, podem ser diferentes (Inderjit \&Callway, 2003), o que corrobora com os resultados encontrados, já que extrato em papel filtro estimulou o crescimento das espécies alvo, e no solo não teve efeito significativo sobre as espécies.

\subsubsection{Efeito da microbiota do solo}

Sabendo-se que os microrganismos presentes no solo podem influenciar quantitativamente e qualitativamente os compostos presentes no solo, esse 
experimento foi realizado para verificar a atividade desses microrganismos presentes no solo na ilha.

Para o crescimento da parte aérea, as duas espécies tiveram um crescimento estatisticamente maior no solo com a presença da microbiota, apenas na concentração de 250ppm de extrato aquoso da raiz de $G$. bonduc (Figura $14 \mathrm{~A} \mathrm{e} \mathrm{C}$ ), do que no solo sem a presença de microbiota.

Para o crescimento da parte radicular observa-se que para rabanete (Figura $14 \mathrm{~B}$ ), novamente o solo que a microbiota foi mantida estimulou 0 crescimento da espécie alvo. A diferença estatística apontou para um crescimento maior de rabanete, tanto no controle quanto com a adição de extrato aquoso na concentração de $125 \mathrm{ppm}$. Novamente, o solo com a presença da microbiota apresentou um crescimento estatisticamente maior da parte radicular de alface como espécie alvo na concentração de 500 ppm (Figura 14 D). 


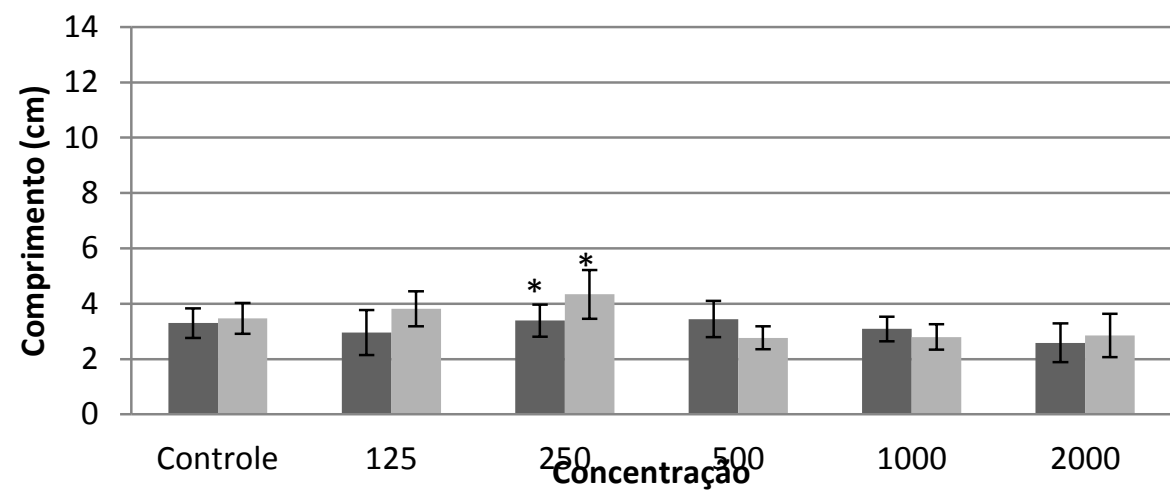

A
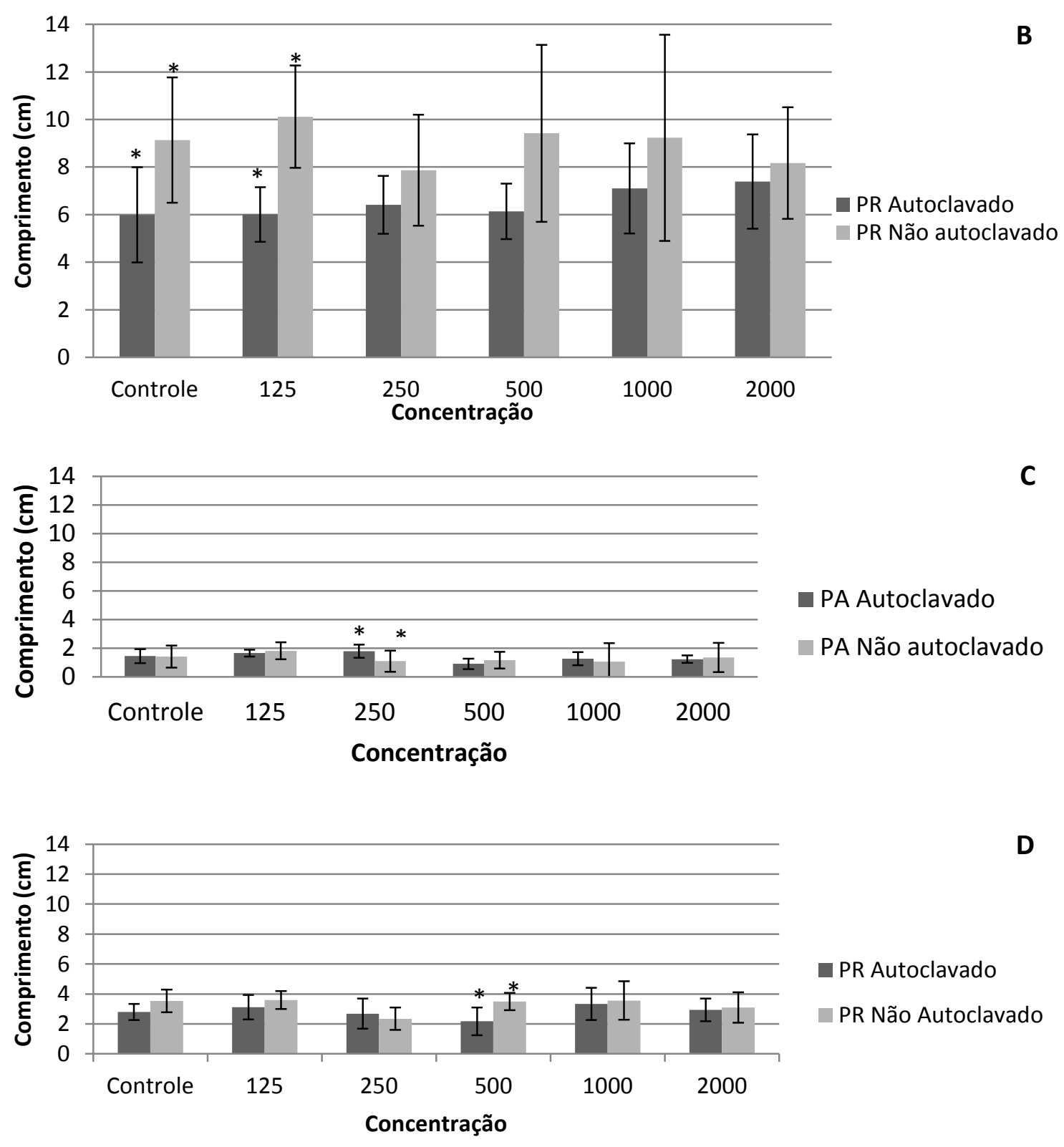

Figura 14. Média do comprimento da parte aérea (PA) e radicular ( $P R$ ) de plântulas de rabanete (Raphanus sativus) (A e B) e alface (Lactuca sativa) ( $C$ e D) submetidas a diferentes concentrações do extrato aquoso radicular de Guilandina bonduc, utilizando solo como substrato com presença da microbiota (não autoclavado) e ausência de microbiota (Autoclavado). * indica diferença estatística em relação aos tratamentos. $p \leq 0,05$. 
Nesse experimento, pode-se observar que sendo que a variação na concentração do extrato adicionado ao solo, e a auclavagem do solo em nada mudou o crescimento das plântulas.

De acordo Inderjit (2005), os microrganismos do solo podem atuar alterando ou degradando moléculas orgânicas, modificando a concentração e/ou atividade de tais substâncias, afetando seus efeitos sobre as espécies receptoras. Assim, a concentração e/ou atividade biológica dos aleloquímicos pode sofrer ação da biota do solo antes que as substâncias sejam absorvidas pela planta receptora, consequentemente afetando a interação alelopática entre as espécies envolvidas (Inderjit \& Weston, 2000). Sabendo-se da importância que os microrganismos do solo possuem sobre as substâncias liberadas no solo, este trabalho mostrou que eles não tiveram influência sobre o extrato adicionado ao solo.

Lankau (2010) avaliando a inibição dos compostos liberados por Alliaria petiolata, espécie invasiva dos sub-bosques do nordeste da América do Norte usando solo como substrato, com presença e ausência de microbiota, a inibição era menor quando a espécie em estudo crescia no solo sem a presença de microbiota. Lankau (2010) reporta esse efeito a microbiota do solo, pois esses podem reduzir os efeitos alelopáticos, por quebrar as moléculas em novos produtos aleloquímicos com maior ou menor toxicidade, ou até mesmo a decomposição desses produtos (Inderjit, 2005).

Mesmo sabendo que a microbiota pode interferir na composição química dos metabólitos adicionados ao solo, na forma de exsudação, lixiviação ou decomposição, foi possível observar nesse experimento que o extrato adicionado ao solo, independente de ter microbiota ou não, não interferiu significativamente no crescimento das espécies alvo.

\subsubsection{Efeito do tipo de solo nas espécies alvo}

Avaliando-se o efeito do solo coletado em diferentes pontos e abaixo da vegetação das espécies que estão interagindo na ilha pode-se observar que as espécies alvo tiveram crescimento semelhante da parte aérea e radicular em ambos os tratamentos. Apenas para alface como espécie alvo pode-se observar que houve diferença no crescimento da parte radicular onde diferiu no solo coletado abaixo da população de $C$. atlanticus (solo 3) e no solo descoberto (solo2) (Figura 15). 

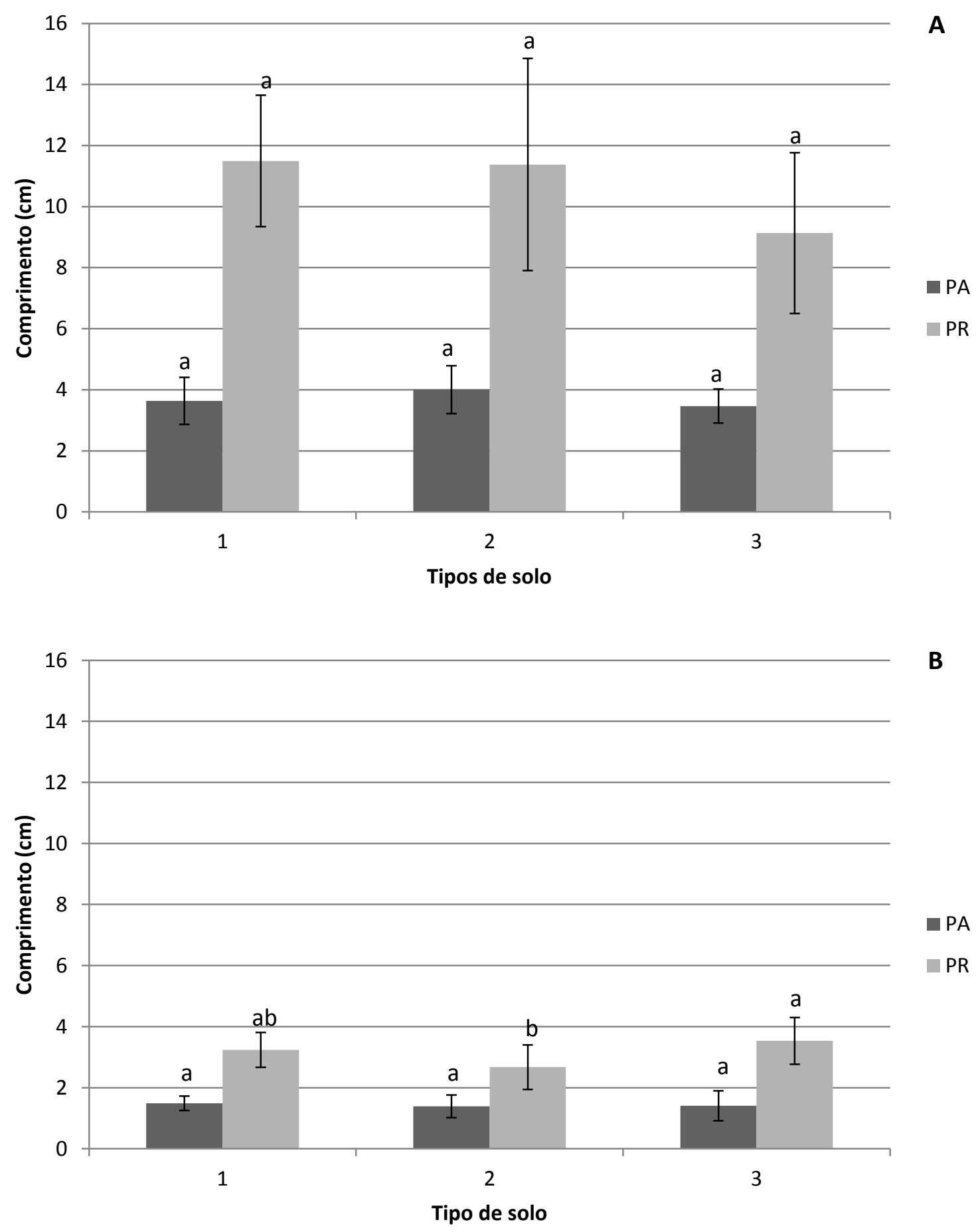

Figura 15. Média do comprimento da parte aérea (PA) e radicular (PR) de plântulas de rabanete (Raphanus sativus) (A) e alface (Lactuca sativa) (B) cultivadas em solo coletado em 3 diferentes pontos da ilha: abaixo da população de Guilandina bonduc itálico (1), solo na formação do halo desprovido de vegetação (2), abaixo da população de Cyperus atlanticus (3). Letras diferentes indicam diferença estatística entre os tratamentos. $p \leq 0,05$. 
As substâncias liberadas por meio de exsudação radicular e de tecidos radiculares estão envolvidos na inibição da germinação e crescimento de espécies de plantas vizinhas em ecossistemas naturais e cultiváveis. Apesar de não testar os compostos sobre $C$. atlanticus, o presente estudo indica que quando testados os extratos e exsudados das raízes de $\mathrm{G}$. bonduc não há inibição do crescimento das espécies alvo, portanto, o fenômeno que se encontra na llha da Trindade possivelmente não possa ser reportado a alelopatia das substâncias liberadas pelas raízes.

As plantas competem por uma grande variedade de recursos no solo, incluindo água e nutrientes essenciais que diferem em dimensão molecular, valência, estado oxidativo e mobilidade (Marschner, 1995) provavelmente o efeito observado na llha de Trindade pode ser causado por competição por recursos. As mudanças na densidade da população de certas espécies também podem afetar a disponibilidade de vários recursos (água, luz e nutrientes) que podem influenciar no crescimento de outras espécies indiretamente, com isso, o papel da competição é reforçado na formação da estrutura e dinâmica das comunidades vegetais (Callaway \& Walker 1997; Gurevitch et al, 2009; Tilman, 1986).

De acordo com a literatura, não existem relatos de que $G$. bonduc apresente o efeito encontrado na liha em outros locais em que ela ocorre. Possivelmente esse fenômeno é encontrado na llha pelo fato de que $C$. atlanticus é uma espécie endêmica e não coexiste no local de origem de $G$. bonduc, a qual pode estar se comportando como "Novel weapons" levando ao seu sucesso no estabelecimento na llha da Trindade.

Nesse estudo apenas o potencial fitotóxico sobre as espécies alvo alface e rabanete foi estudado, não levando em conta o papel da competição por recursos. De acordo com os resultados obtidos foi possível observar que alelopatia de raízes no solo não é o principal responsável pela formação dos halos formados na llha da Trindade.

\subsection{Comparação dos perfis cromatográficos dos extratos e exsudados radiculares}

Os perfis cromatográficos das amostras foram analisados em dois comprimentos de onda $280 \mathrm{~nm}$ e $354 \mathrm{~nm}$. Com base nos perfis cromatográficos e os espectros de absorção dos picos, a análise comparativa mostrou que o exsudado radicular, o extrato metanólico e o extrato aquoso são diferentes quanto a sua composição química (Figura 16 e Figura 17). 

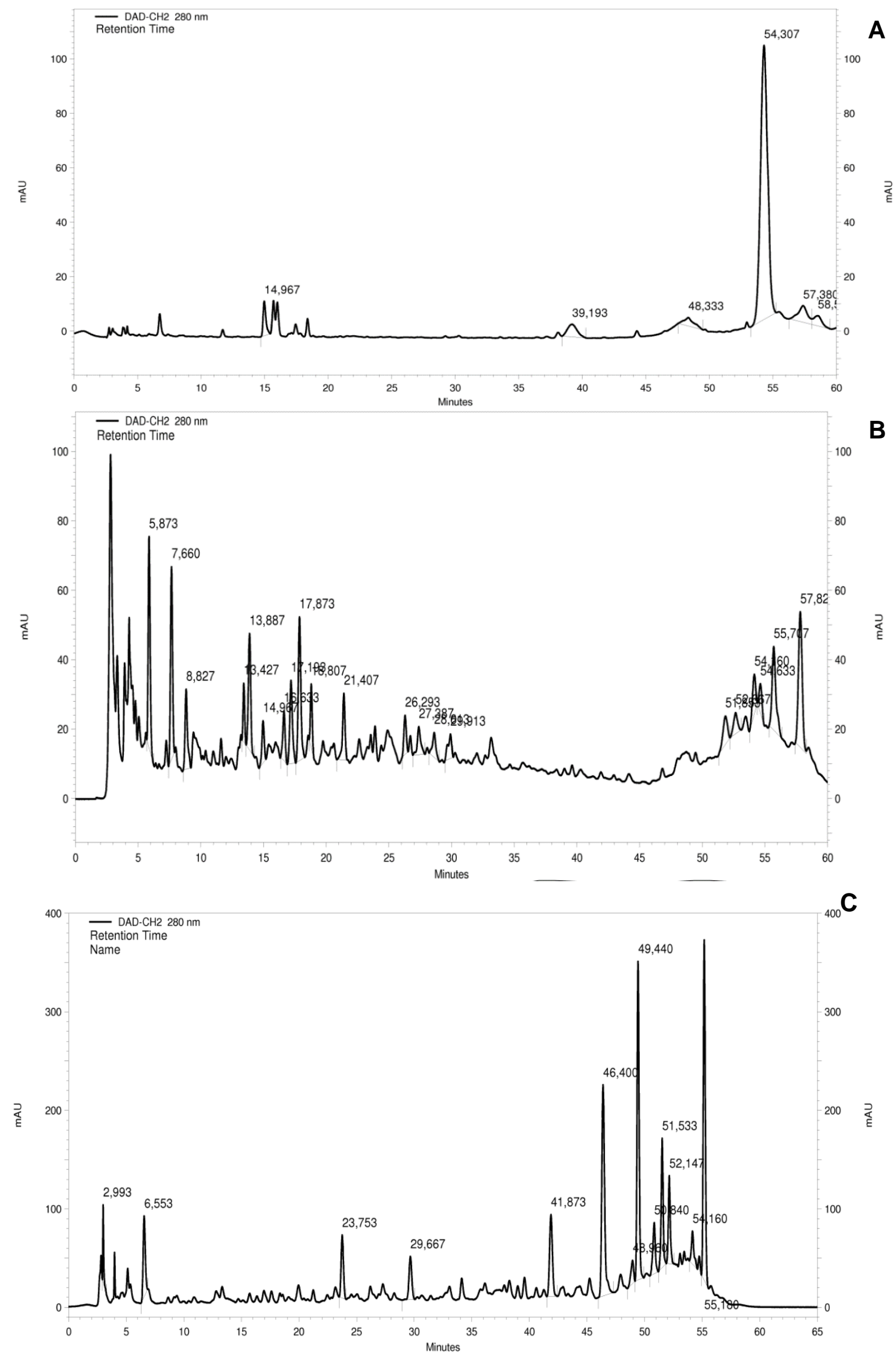

Figura 16. Perfis cromatográficos registrado em $280 \mathrm{~nm}$ de exsudado radicular (A), extrato aquoso (B) e extrato metanólico bruto (C) de raízes de Guilandina bonduc obtido a partir de HPLC. 

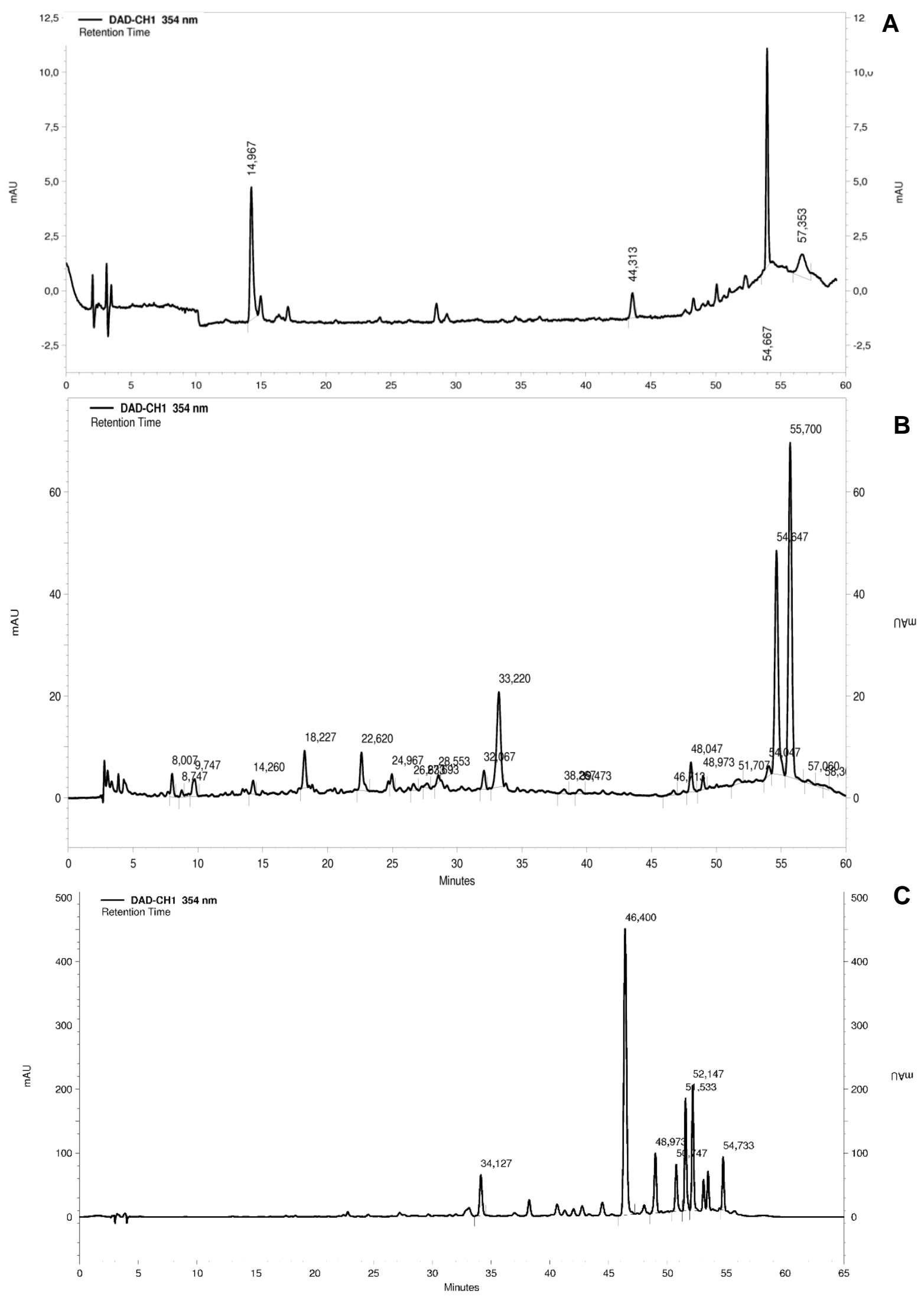

Figura 17. Perfis cromatográficos registrado em $354 \mathrm{~nm}$ de exsudado radicular (A), extrato aquoso (B) e extrato metanólico bruto (C) de raízes de Guilandina bonduc obtido a partir de HPLC 
Skoog e colaboradores (2002) afirmam que se a amostra não produz um pico no mesmo tempo de retenção que uma determinada substância, usando condições idênticas, pode-se considerar que a substância em questão está ausente, ou a sua presença ocorre em níveis de concentração abaixo do limite de detecção do equipamento.

O uso de água ou solventes orgânicos / inorgânicos, para extração de metabólitos secundários deve ser avaliado, pois existem diferenças qualitativas e quantitativas entre os aleloquímicos extraídos nos diferentes tipos de solvente, devido ao grau de polaridade dos solventes utilizados (Inderjit \& Dakshini, 1995). Apesar de água e metanol serem considerados solventes polares, o índice de polaridade dos dois são distintos, 9 e 5,1 respectivamente. Isso pode justificar a diferença quantitativa e qualitativa dos extratos.

Diversos trabalhos envolvendo estudos alelopáticos utilizam solventes orgânicos para extrair as substâncias presentes nos tecidos das plantas para testar a sua atividade em espécies alvo. A extração com solventes orgânicos é criticada já que é um processo que não ocorre naturalmente no meio ambiente e então não pode ser considerado um estudo de alelopatia. Já o uso de água para a extração é considerado um processo positivo, pois é um procedimento que se aproxima do que ocorre em condições naturais, como a lixiviação das folhas durante um processo de precipitação. Embora, a maioria dos tecidos das plantas contenham substâncias com potencial alelopático, apenas aquelas substâncias que são liberadas pelas plantas para o ambiente estão disponíveis para exercer um efeito alelopático em outro organismo (Putnan \& Tang, 1986). Alguns estudos mostraram que as substâncias que estavam presentes nos tecidos das raízes de trigo, não eram liberadas para o meio através da exsudação radicular (Pérez \& Ormeño-Núñes, 1991; Wu et al., 2001). Portanto, substâncias que estão presentes nos tecidos das plantas quando extraídos com solventes orgânicos ou água, podem mostrar um efeito inibitório ou estimulatório sobre as espécies alvo em estudo, mas pode ser que essas mesmas substâncias não sejam lixiviados ou exsudados pelas plantas em condições naturais ( $\mathrm{Li}$ et al., 2010).

Portanto, mesmo utilizando água como solvente para a extração dos compostos aleloquímicos não garante que os compostos extraídos são os mesmos que são liberados de forma natural pelas plantas. Os cromatogramas gerados a partir dos extratos aquosos, metanólico e exsudados radiculares, mostraram que cada um apresenta compostos quantitativamente e qualitativamente distintos. Isso mostra o porquê os resultados dos bioensaios foram tão diferentes para os 3 tipos de extratos analisados. 


\subsection{Identificação por RMN}

Uma análise dos espectros gerados através da Ressonância Magnética Nuclear pelas análises 1H, 13C, COSY e DEPT levou a elucidação da estrutura (Figura 18), sendo esse composto identificado como Caesaldekarin C, pertencente a classe cassane furanoditerpeno. O composto possui massa molecular de 346, e sua fórmula molecular é $\mathrm{C}_{21} \mathrm{H}_{30} \mathrm{O}_{4}$. A estrutura molecular está representada na Figura 18.

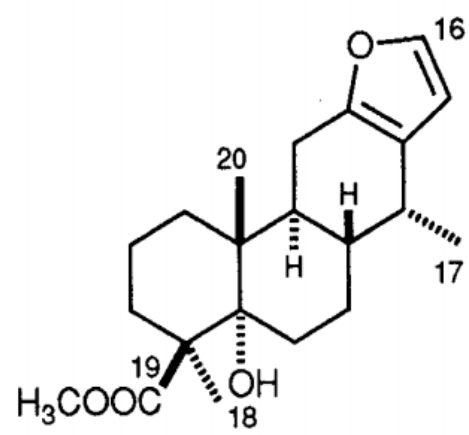

caesaldekarin c

Figura 18. Estrutura molecular de Caesaldekarin $C$ isolado a partir do fracionamento liquidoliquido e coluna cromatográfica do extrato metanólico da raiz de Guilandina bonduc L

As plantas que pertencem ao gênero Caesalpinia (Fabaceae), têm provado ser uma fonte rica de cassane furanoditerpenos havendo inúmeros relatos na literatura da ocorrência desse compostos dentro do gênero estudado (Balmain et al., 1967; Balmain et al., 1970; Kinoshita et al., 1996, Kitagawa et al., 1996; Lyder et al., 1998; Ogawa et al., 1992; Pascoe et al., 1986, , Peters et al., 1997; e Peter et al., 1998). Essas substâncias exibem atividades biológicas interessantes, tais como antivirais (Jiang et al., 2001), antimalárico, (Banskota et al., 2003; Kalanui et al., 2006) atividade antibacteriana e antioxidante (Dickson et al., 2007).

A estrutura molecular deste tipo de diterpenóide é construído a partir da fusão de três anéis de ciclo-hexano e um anel de furano (Jiang et al., 2001). Na maioria dos casos a determinação estrutural foi baseada em métodos espectroscópicos.

Este composto também já foi isolado das raízes de Caesalpinia major (Kitagawa et al, 1996) e Caesalpinia bonducella (Peter et al., 1998), sinonímia de G. bonduc, Vouacapoua americana, Vouacapoua macropétala e Caesalpinia benthamiana (Dickson et al., 2007), sendo todas as espécies pertencentes a família Fabaceae. Alguns dos extratos de plantas do gênero Caesalpinia apresentam atividades biológicas interessantes, como: extratos das folhas de Guilandina bonduc ajudam na contração do musculo liso uterino (Datte et al., 1998), extrato aquoso e etanólico de sementes de $G$. bonduc apresentam atividade hipoglicêmica, hipolipídica e anti-hiperglicêmica, podendo 
ser utilizadas no controle da diabetes e colesterol (Ahamed, 2013; Sharma et al, 1997), o extrato etanólico da casca de Caesalpinia pyramidalis (Santos et al., 2011). Em estudos referentes ao composto Caesaldekarin C, Dickson e colaboradores (2007), encontraram atividade antioxidante e antibactericida, podendo ser utilizado como medicamento de uso tópico. Não há nenhum relato de atividade fitotóxica de Caesaldekarin $\mathrm{C}$ sobre outras espécies.

\subsection{Bioatividade do produto isolado}

O produto isolado a partir do extrato metanólico das raízes de G. bonduc, Caesaldekarin C, apresentou estímulo e inibição do crescimento da parte aérea e radicular para rabanete como espécie alvo (Figura 19 A). A parte aérea apresentou estímulo de crescimento estatisticamente significativo nas concentrações de 10, 30, e 300 $\mu \mathrm{M}$, e na concentração de $1000 \mu \mathrm{M}$ ocorreu inibição do crescimento da parte aérea da espécie alvo. Para o crescimento da parte radicular, apenas nas concentrações de 30 e $100 \mu \mathrm{M}$ apresentou estímulo de crescimento e em $1000 \mu \mathrm{M}$ o crescimento da raiz foi inibido (Figura $19 \mathrm{~A}$ )

O produto Caesaldekarin $\mathrm{C}$ provocou uma redução no comprimento da radícula de plântulas de alface, sendo os efeitos inibitórios crescentes com 0 aumento da concentração dos extratos utilizados. (Figura 19 B)As concentrações de $300 \mu \mathrm{M}$ e $1000 \mu \mathrm{M}$ apresentaram um efeito inibitório estatisticamente significativo em relação ao controle. A resposta de crescimento do hipocótilo de alface apresentou inibição do crescimento estatisticamente significativo em todas as concentrações testadas com exceção de $10 \mu \mathrm{M}$ que apresentou estímulo do crescimento mas não foi estatisticamente significativo (Figura $19 \mathrm{~B})$. 

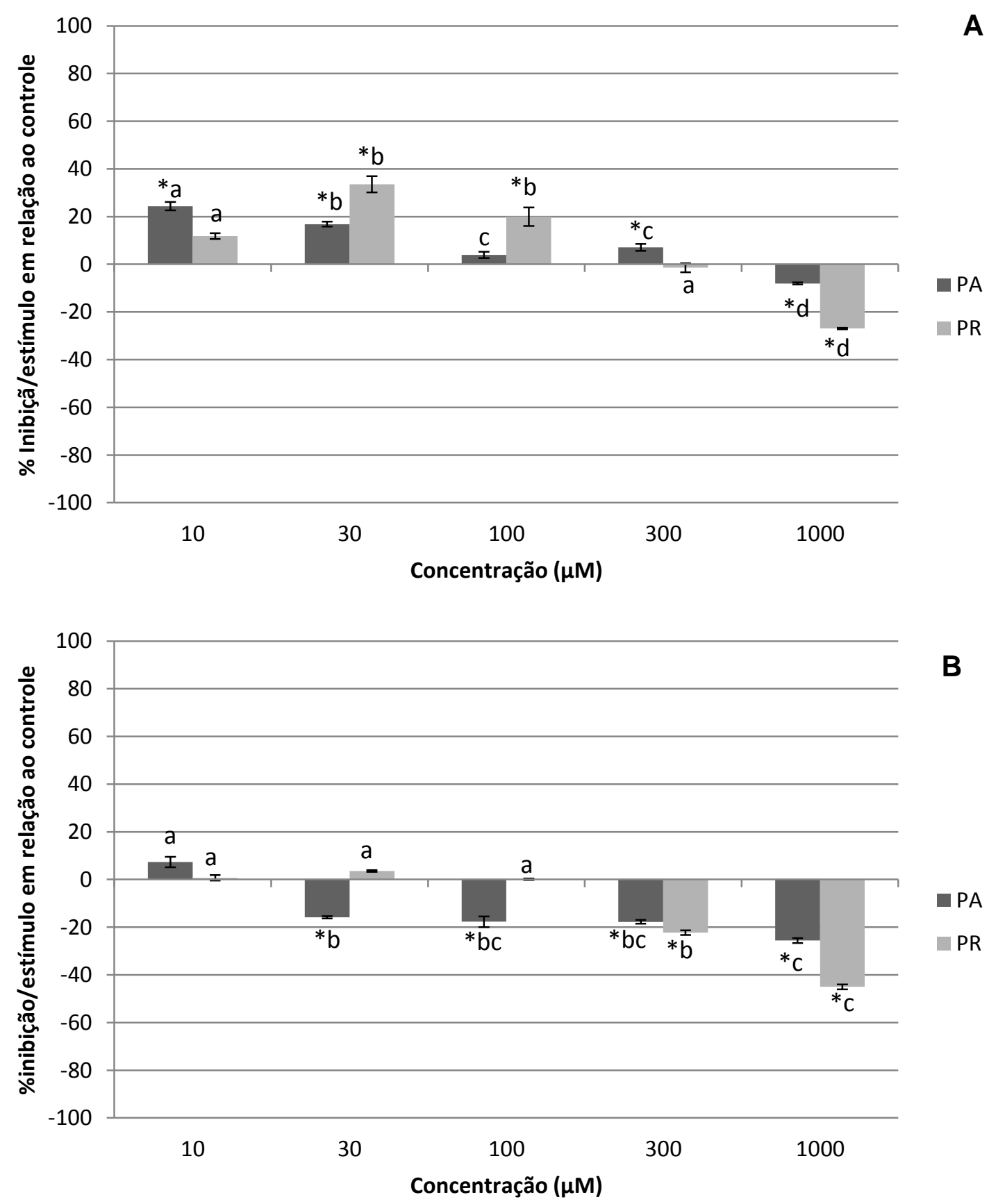

Figura 19. Porcentagem de inibição/estímulo no crescimento inicial, da parte aérea (PA) e radicular (PR) das plântulas de rabanete (Raphanus sativus) (A) dias e plântulas de alface (Lactuca sativa) (B), sob influência de Caesaldekarin $\mathrm{C}$ isolado do extrato metanólico radicular de Guilandina bonduc. Letras diferentes indicam diferença estatística entre os tratamentos $e^{*}$ indica diferença estatística em relação ao controle. $p \leq 0,05$.

Quando se verificou o estado das plântulas sob influência de Caesaldekarin C, foi observado que as raízes na concentração de $1000 \mu \mathrm{M}$ apresentavam-se defeituosas, oxidadas e escurecidas em ambas as espécies alvo Sabe-se que os aleloquímicos podem causar efeitos sobre o sistema radicular da planta, como a redução no número de raízes, inchaço ou necrose de pontas de raiz, falta de pêlos radiculares, podendo reduzir assim a capacidade de sobrevivência da plântula (Elisante et al, 2013). Diversos trabalhos 
encontraram tal efeito sobre as raízes, sendo esse um efeito comum quando se avalia 0 comportamento dos compostos sobre as espécies alvo (Bich \&Kato-Noguchi, 2012; Reigosa et al., 2013; Carvalho et al., 2014)

Os resultados obtidos neste estudo mostram que o extrato bruto metanólico das raízes de $G$. bonduc e o composto puro apresentam perfis de atividade semelhantes no crescimento das plântulas nos bioensaios. Portanto, pode-se considerar que este composto é o aleloquímico que contribui consideravelmente com a atividade inibitória apresentada pelo extrato metanólico das raízes desta planta.

Rezende e colaboradores (2011), analisando a fitotoxicidade de extratos de Caryocar brasiliense, encontraram um efeito maior do extrato bruto metanólico do caule quando comparado às frações obtidas do mesmo extrato. Santos e colaboradores (2008) testaram a atividade de duas substâncias isoladas de Brachiaria brizantha cv. Mandacaru na germinação e no crescimento de Mimosa pudica e Senna obtusifolia, os autores verificaram um efeito sinérgico das duas substâncias, sendo que tanto na germinação como no crescimento das espécies-alvo quando testadas isoladamente tiveram efeito diminuído em relação ao efeito das substâncias em conjunto. Pode-se notar esse efeito, já que a inibição causada no extrato metanólico bruto é maior quando comparado com o produto isolado.

A atividade fitotóxica deste produto sobre espécies alvo,foi avaliado pela primeira vez neste trabalho, sendo que sua atividade só havia sido testada para fins farmacêuticos.

\section{Conclusões}

A partir das análises realizadas com exsudados, extrato aquoso e metanólico das raízes de $G$. bonduc verificou-se que:

1. As raízes de $G$. bonduc exsudam maior quantidade de compostos em plantas com menor biomassa;

2. A estimativa de exsudados liberados em campo,se aproxima das concentrações testadas nos bioensaio em laboratório;

3. Os exsudados liberados pela G. bonduc, em condições de laboratório, tem causado efeito estimulatório no crescimento nas espécies alvo estudadas;

4. O extrato aquoso das raízes de G. bonduc também apresentou efeito estimulatório nas espécies alvo estudadas; 
5. O extrato metanólico promoveu inibição do crescimento, mostrando que a extração solvente orgânica tem produtos mais fitotóxicos;

6. As substâncias presentes nos exsudados radiculares, extrato aquoso e metanólico das raízes de $G$. bonduc são diferentes quantitativamente e qualitativamente

7. O extrato aquoso adicionado ao solo não apresenta efeito sobre as espécies alvo;

8. A microbiota presente no solo da llha de Trindade não interfere nos compostos adicionados ao solo não interferindo no crescimento das espécies alvo;

9. O composto isolado do extrato metanólico foi um furanoditerpeno (Caesaldekarin C)

10. Caesaldekarin C promoveu inibição do crescimento em alface e estimulo e inibição em rabanete.

11.0 efeito da alelopatia possivelmente não é o responsável pelo fenômeno que ocorre na llha da Trindade

\section{Referências bibliográficas}

ABDELGALEIL, S. A., \& HASHINAGA, F. 2007. Allelopathic potential of two sesquiterpene lactones from Magnolia grandiflora L. Biochemical Systematics and Ecology, 35(11), 737742.

AHAMED, R. N. (2013). Effect of Caesalpinia bonducella seed extract on histoarchitecture of some vital organs and clinical chemistry in female albino rats. Journal of King Saud University-Science, 25(1), 1-6.

ALMEIDA, F. S. 1991. Controle de plantas daninhas em plantio direto. Londrina: Circular 67. lapar, 34p.

ALVES, R. J. V. 1998. Ilha da Trindade e Arquipélago Martin Vaz- Um Ensaio Geobotânico.- Serviço de Documentação, Marinha do Brasil; 144 p., Diretoria de Hidrografia e Navegação, Niterói, RJ. 
ALVES, R. J. V.; SILVA, N. G. DA \& AGUIRRE-MUÑOZ A. 2011. Return of endemic plant populations on Trindade Island, Brazil, with comments on the fauna. In: VEITCH, C. R.; CLOUT, M. N. \& TOWNS, D. R. (eds). Island Invasives: Eradication and Management. Proceedings of the International Conference on Island Invasives. Gland, Switzerland: IUCN and Auckland. New Zealand. p. 259-263

ALVES, S.M. \& SANTOS, L.S. 2002. Natureza química dos agentes alelopáticos. In: SOUZA FILHO, A.P.S \& ALVES, S.M (eds). Alelopatia: princípios básicos e aspectos gerais. Belém: Embrapa Amazônia Oriental. p. 25-47.

ALVES, S.M.; ARRUDA, M.S.P.; SOUZA FILHO, A.P.S. 2002. Biossíntese e distribuição de substâncias alelopáticas. In: SOUZA FILHO, A.P.S \& ALVES, S.M (eds). Alelopatia: princípios básicos e aspectos gerais. Belém: Embrapa Amazônia Oriental. 79-109.

AULAKH, M. S., WASSMANN, R., BUENO, C., \& RENNENBERG, H. 2001. Impact of root exudates of different cultivars and plant development stages of rice (Oryza sativa L.) on methane production in a paddy soil. Plant and Soil,230(1), 77-86.

AVALOS GARCÍA, A., \& PÉREZ-URRIA CARRIL, E. (2009). Metabolismo secundario de plantas. Reduca (Biología), 2(3).

BADRI, D. V., \& VIVANCO, J. M. 2009. Regulation and function of root exudates. Plant, Cell \& Environment, 32(6), 666-681.

BAETZ, U.; MARTINOIA, E. 2014. Root exudates: the hidden part of plant defense. Trends in Plant Science.

BAIS HP, PARK SW,WEIR TL, CALLAWAY RM,VIVANCO JM. 2004. How plants communicate using the underground information superhighway. Trends in Plant Science. 9:26-32 
BAIS, H. P., WEIR, T. L., PERRY, L. G., GILROY, S., \& VIVANCO, J. M. 2006. The role of root exudates in rhizosphere interactions with plants and other organisms. Annual Review of Plant Biology. 57: 233-266.

BAIS, H.P.; VEPACHEDU, R.; GILROY, S.; CALLAWAY, R.M.;VIVANCO, J.M. 2003. Allelopathy and exotic plant invasion: from molecules and genes to species interactions. Science 301:1377-80

BALMAIN, A., BJ, K., CONNOLLY, J. D., \& FERGUSON, G. 1967. The constitution and stereochemistry of $\varepsilon$-caesalpin. Tetrahedron Letters, 8(49), 5027-5031.

BALMAIN, A.; CONNOLLY, J. D.; FERRARI, M.; GHISALBERTI, E. L.; PAGNONI, U. M.; PELIZZONI, F. 1970. The stereochemistry of the furanoditerpenoids $\alpha-, \beta-$, and $\delta$ caesalpin. Journal of the Chemical Society: Chemical Communications. 1970: 1244-1245.

BANSKOTA, A. H., ATTAMIMI, F., USIA, T., LINN, T. Z., TEZUKA, Y., KALAUNI, S. K., \& KADOTA, S. 2003. Novel norcassane-type diterpene from the seed kernels of Caesalpinia crista. Tetrahedron letters, 44(36), 6879-6882.

BARCELÓ, J., \& POSCHENRIEDER, C. (2002). Fast root growth responses, root exudates, and internal detoxification as clues to the mechanisms of aluminium toxicity and resistance: a review. Environmental \& Experimental Botany, 48(1), 75.

BARTO, E. K., \& CIPOLLINI, D. 2009. Half-lives and field soil concentrations of Alliaria petiolata secondary metabolites. Chemosphere, 76(1), 71-75.

BAZZAZ, F. A., CHIARIELLO, N. R., COLEY, P. D., \& PITELKA, L. F. (1987). Allocating resources to reproduction and defense. BioScience, 58-67.

BELEL, M. D., \& RAHIMATU, D. B. 2012. Allelopathic Effect of Cyperus tuberosus Seed and Leaf Extract on Seedling Growth of Groundnuts (Arachis hypogaea). Journal of Agriculture and Social Sciences (Pakistan). 
BERG, G., SMALLA, K. (2009): Plant species and soil type cooperatively shape the structure and function of microbial communities in the rhizosphere. FEMS Microbiol. Ecol. $68,1-13$

BICH, T. T. N., \& KATO-NOGUCHI, H. (2012). Allelopathic potential of two aquatic plants, duckweed (Lemna minor L.) and water lettuce (Pistia stratiotes L.), on terrestrial plant species. Aquatic Botany, 103, 30-36.

BLUM, O. 2011. Plant-Plant Allelopathic Interaction. Phase II: Field/Laboratory Experiments. In: BLUM, O. Plant-Plant Allelopathic Interaction: North Carolina State University: Springer.p. 86-149.

BORELLA, J., MARTINAZZO, E. G., AUMONDE, T. Z., AMARANTE, L., MORAES, D. M., \& VILLELA, F. A. 2012. Respostas na germinação e no crescimento inicial de rabanete sob ação de extrato aquoso de Piper mikanianum (Kunth) Steudel. Acta Botanica Brasilica, 26(2), 415-420.

CALABRESE, E. J., BLAIN, R. B. 2011. The hormesis database: the occurrence of hormetic dose responses in the toxicological literature. Regulatory Toxicology and Pharmacology, 61(1), 73-81.

CALLAWAY, R. M. \& RIDENOUR, W. M. 2004. Novel weapons: invasive success and the evolution of increased competitive ability. Frontiers in Ecology and the Environment 2: $436-443$

CALLAWAY, R. M., \& WALKER, L. R. 1997. Competition and facilitation: a synthetic approach to interactions in plant communities. Ecology, 78(7), 1958-1965.

CALLAWAY, R. M., ASCHEHOUG, E. T. 2000) Invasive plants versus their new and old neighbors: a mechanism for exotic invasion. Science, 290(5491), 521-523. 
CARPANEZZI, F. B., GUALTIERI, S. C. J. 2014. Alelopatia de extratos aquosos foliares da exótica invasora Pittosporum undulatum na germinação e crescimento do capimarroz. Pesquisa Florestal Brasileira, 34(79), 173-179.

CARVALHO, M. S.; AMORIM P.R.F.; CÂMARA, P.E.A.S. 2013. New Goats on the Island. Rodriguésia, 64: 661-663.

CARVALHO, S. J. C. 1993. Caracterização dos efeitos alelopáticos de Brachiaria brizantha cv. Marandu no estabelecimento das plantas de Stylosanthes guianensis var. vulgaris e cv. Bandeirante. Revista Sociedade Brasileira de Zootecnia. 22(6): 930-937

CARVALHO, W. P., DE CARVALHO, G. J., ABBADE NETO, D. D. O., VIEIRA TEIXEIRA, L. G. (2014). Allelopathy of green manures extracts on germination and initial growth of the lettuce.Bioscience Journal, 30(3), 1-11.

CHAKRABARTI, S., BISWAS, T.K., ROKEYA, B., ALI, L., MOSIHUZZAMAN, M., NAHAR, N., KHAN-AZAD, A.K., MUKHERJEE, B., (2003). Advanced studies on the hypoglycemic effect of Caesalpinia bonducella F. in type 1 and 2 diabetes in Long Evans rats. Journal of Ethnopharmacology 84, 41-46.

CHEN, I. 1992. A conceptual framework for assessing allelochemicals in soil environment. In Allelpathy: Basic and applied Aspects (Rizvi, S. J.\& Rizvi, V., eds.). Londres: Capman \& Hall. p. 21-29.

CHEN, L., LIAO, L., WANG, S., HUANG, Z. AND XIAO, F. 2002. Effect of Vanillin and Phydroxybenzoic acid on Physiological Characteristics of Chinese Fir Seedlings. The journall of Applied Ecology, 13, 1291.

CHON, S. U., COUTTS, J. H., \& NELSON, C. J. 2000. Effects of light, growth media, and seedling orientation on bioassays of alfalfa autotoxicity. Agronomy Journal, 92(4), 715720 . 
CHUNG, I. M.; AHN, J. K.; YUN, S. J. 2001. Assessment of allelopathic potential of barnyard grass (Echinochloa crus-gall) on rice (Oriza sativa L.) cultivars. Crop Protection, 20 (10): 921-928.

COMAS, L. H., BECKER, S. R., VON MARK, V. C., BYRNE, P. F., \& DIERIG, D. A. (2013). Root traits contributing to plant productivity under drought. Frontiers in plant science, 4. communities. Plant ecology, 51-75.

CORREIA, N.; CENTURION, M., ALVES, P. 2005. Influência de extratos aquosos de sorgo sobre a germinação e desenvolvimento de plântulas de soja. Ciência Rural , 35 (3):498-503.

CRUZ-ORTEGA, R., ANAYA, A.L., HERNÁNDEZ-BAUTISTA, B.E. AND LAGUNAHERNÁNDEZ, G. 1998. Effects of Allelochemical Stress Produced by Sicyos deppei on Seedling Root Ultrastructure of Phaseolus vulgaris and Cucurbita ficifolia. Journal of Chemical Ecology, 24: 2039-2057.

CRUZ-ORTEGA, R., LARA-NÚÑEZ, A. AND ANAYA, A.L. 2007. Allelochemical Stress Can Trigger Oxidative Damage in Receptor Plants: Mode of Action of Phytotoxicity. Plant Signaling \& Behavior, 2: 269-270.

DANA, E. D., \& DOMINGO, F. 2006. Inhibitory effects of aqueous extracts of Acacia retinodes Schltdl., Euphorbia serpens L. and Nicotiana glauca Graham on weeds and crops. Allelopathy Journal, 18(2), 323-330.

DATTE, J.Y., YAPO, P.A., KOUAME-KOFFI, G.G., KATI-COULIBALY, S., AMOIKON, K.E., OFFOUMOU, A.M. 2004. Leaf extract of Caesalpinia bonduc Roxb. (Caesalpiniaceae) induces an increase of contractile force in rat skeletal muscle in situ. Phytomedicine 11: 235-241.

DATTE, J.Y.; TRAORE, A.; OFFOUMOU, A. M.; ZIEGLER, A. 1998. Effects of leaf extract of Caesalpinia bonduc (Caesalpiniaceae) on the contractile activity of uterine smooth muscle of pregnant rats. Journal of Ethnopharmacology, 60: 149-155 
DE-LA-PENA C., LEI Z., WATSON B.S., SUMNER L.W. \& VIVANCO J.M. 2008. Rootmicrobe communication through protein secretion. Journal of Biological Chemistry. 283, 25247-25255

DEWICK, M. P. 2002. Medicinal Natural Products: A Biosynthetic Approach. 2 Ed. John Wiley \& Sons Ltd.

DICKSON, R. A., HOUGHTON, P. J., \& HYLANDS, P. J. 2007. Antibacterial and antioxidant cassane diterpenoids from Caesalpinia benthamiana.Phytochemistry, 68(10), 1436-1441.

DUARTE, R.H.; HORTA, G.C.M.M. 2012. Barth e a ilha da Trindade, 1957-1959. 2012. História, Ciências, Saúde - Manguinhos, Rio de Janeiro, 19(3):951-968.

DUKE, S. O. 2010. Allelopathy: current status of research and future of the discipline: a commentary. Allelopathy Journal, 25(1), 17-30.

EINHELLIG F.A. 1995. Allelopathy: Current status and future goals. In: Allelopathy. Organisms, Processes and Applications. ACS Simposium, Washington, ed. Inderjit; K.M.M.; Dakshimi \& F.A. Einhellig. American Chemical Societies, Series 582, New York. pp. 1-24

EL ZAHAR HAICHAR, F., SANTAELLA, C., HEULIN, T., \& ACHOUAK, W. (2014). Root exudates mediated interactions belowground. Soil Biology and Biochemistry, 77, 69-80.

ELISANTE, F., TARIMO, M. T., \& NDAKIDEMI, P. A. (2013). Allelopathic Effect of Seed and Leaf Aqueous Extracts of Datura stramonium on Leaf Chlorophyll Content, Shoot and Root Elongation of Cenchrus ciliaris and Neonotonia wightii. American Journal of Plant Sciences, 2013.

FERREIRA, A. G.; AQUILA, M.E.A. 2000. Alelopatia: uma área emergente da ecofisiologia. Revista Brasileira de Fisiologia Vegetal, 12(1): 175-204. 
FERREIRA, A.G. 2004. Interferência, competição e alelopatia. In: FERREIRA, A.G \& BORGHETTI, F. (eds). Germinação: do básico ao aplicado. Porto Alegre: Artmed. p.251262.

FRANCIS, J. K. 2000. Caesalpinia bonduc (L.) Roxb. Gray nicker bean. Fabaceae. Disponível em http://www.fs.fed.us/global/itt/pdf/shrubs/Caesalpinia\%20bonduc.pdf. Acesso em 21 Nov.2013

GALINDO, J.C.G., MACÍAS, F.A., GARCÍA-DÍAZ, M.D. AND JORRÍN, J. 2003. Chemistry of the Host-Parasite interactions. In MACÍAS, FA, GALINDO, JCG, MOLINILLO, JMG, AND CUTLER, $\mathrm{H}$. (eds.) Allelopathy: Chemistry and Mode of Action of Allelochemicals. CRC Press, LLC, BocaRaton, FL

GARCIA J.A.L., BARBAS C., PROBANZA A., BARRIENTOS M.L. \& MANERO F.J.G. 2001. Low molecular weight organic acids and fatty acids in root exudates of two Lupinus cultivars at flowering and fruiting stages. Phytochemical Analysis 12, 305-311.

GAUR, R.L.; SAHOO, M.K.; DIXIT, S.; FATMA, N.; RASTOGI, S.; KULSHRESHTHA, D.K.; CHATTERJEE, R.K.; MURTHY, P.K. 2008. Antifilarial activity of Caesalpinia bonducella against experimental filarial infections. Indian Journal of Medical Reseach. 128(1):65-70.

GLEASON, K.F. CHOLLET, R. 2012. Isoprenoid compounds (Terpenes). In: GLEASON, K.F. CHOLLET, R. Plant Biochemistry. 1ed. Jones \& Bartlett Learning. 100-118.

GÓMEZ-ARCHILA, L. G., RUGELES, M. T., \& ZAPATA, W. 2014. Actividad antiviral de compuestos aislados de esponjas marinas. Revista de biología marina y oceanografía, 49(3), 401-412.

GONZALES, L.; REIGOSA, M.J. 2001. Allelophaty in Agroecosystems in Spain. Journal of Crop Production, 4(2): 415-432. 
GRANSEE, A., WITTENMAYER, L. (2000): Qualitative and quantitative analysis of watersoluble root exudates in relation to plant species and development. J. Plant Nutr. Soil Sci. 163, 381-385.

Groleau-RenAUd, V., PlantureuX, S., TUBeIleH, A., GUCKERT, A. (2000): Influence of microflora and composition of root bathing solution on root exudation of maize plants. J. Plant Nutr. 23, 1283-1301.

GULMON, S. L., \& MOONEY, H. A. 1986. Costs of defense and their effects on plant productivity. In On the economy of plant form and function: proceedings of the Sixth Maria Moors Cabot Symposium, Evolutionary Constraints on Primary Productivity, Adaptive Patterns of Energy Capture in Plants, Harvard Forest, August 1983. Cambridge [Cambridgeshire]: Cambridge University Press, c1986..

GUNN CR, DENNIS JV. 1999 World guide to tropical drift seeds and fruits. Krieger Publishing Company. Florida, 242.

GUPTA, M., MAZUMDER, U. K., KUMAR, R. S., \& KUMAR, T. S. 2003. Studies on antiinflammatory, analgesic and antipyretic properties of methanol extract of Caesalpinia bonducella leaves in experimental animal models. Iranian Journal of Pharmacology \& Therapeutics, 2(2), 30-34.

GUREVITCH, J.; SCHEINER, S.M. \& FOX, G.A. 2009. Ecologia Vegetal. 2 ed. Artmed, Porto Alegre, 574p.

GUSMÃO, L.G.S. 2005. Nossas Ilhas Oceânicas: Ilha da Trindade e Arquipélago Martin Vaz. In: SERAFIM, C.F.S.; CHAVES, P.T. Geografia: ensino fundamental e ensino médio: O mar no espaço geográfico brasileiro. Brasília: Ministério da Educação, Secretaria de Educação Básica, Coleção explorando o ensino. (8): 304

HADACEK, F. 2002. Secondary metabolites as plant traits: Current assessment and future perspectives. Critical Reviews in Plant Sciences 21(4): 273-322. 
HINSINGER, P. (2001): Bioavailability of soil inorganic $P$ in the rhizosphere as affected by root-induced chemical changes: a review. Plant Soil 237, 173-195.

HOEKENGA, O. A., VISION, T. J., ShAFF, J. E., MONFORTE, A. J., LEE, G. P., HOWELL, S. H., \& KOCHIAN, L. V. 2003. Identification and characterization of aluminum tolerance loci in Arabidopsis (Landsberg erectax Columbia) by quantitative trait locus mapping. A physiologically simple but genetically complex trait. Plant Physiology, 132(2), 936-948.

HUOT, B., YAO, J., MONTGOMERY, B. L., \& HE, S. Y. 2014. Growth-defense tradeoffs in plants: a balancing act to optimize fitness. Molecular plant, 7(8), 1267-1287.

INDERJIT 2005 Soil microorganisms: an important determinant of allelopathic activity. Plant Soil 274, 227-236

INDERJIT, OLOFSDOTTER, M., STREIBIG, J.C. 2001. Laboratory bioassay for phytotoxicity: an example from wheat straw. Agronomy Journal 93: 43-48

INDERJIT. 2005. Soil microorganisms: an important determinant of allelopathic activity. Plant and Soil, 274(1-2): 227-236.

INDERJIT; Callaway, R. M. 2003. Experimental designs for the study of allelopathy.Plant and soil, 256(1), 1-11.

INDERJIT; Dakshini, K. M. M. 1995. On laboratory bioassays in allelopathy. The Botanical Review, 61(1), 28-44.

INDERJIT; WESTON, A. 2000. Are laboratory bioassays for allelopathy suitable for prediction of field responses? Journal of Chemical Ecology (26)9: 2111-2118.

IWASA, Y. 2000. Dynamic optimization of plant growth. Evolutionary Ecology Research, 2(4), 437-455. 
JIANG, R. W., BUT, P. P., MA, S. C., \& MAK, T. C. 2001. Furanoditerpenoid lactones from the seeds of Caesalpinia minax Hance. Phytochemistry, 57(4), 517-521.

JONES, D. L., HODGE, A., KUZYAKOV, Y. (2004): Plant and mycorrhizal regulation of rhizodeposition. New Phytol. 163, 459-480.

JOSE, S.; GILLESPIE A.R. 1998. Allelopathy in black walnut (Juglans nigra L.) alley cropping. I. Spatio-temporal variation in soil juglone in a black walnut-corn (Zea mays L.) alley cropping system in the midwestern USA. Plant Soil 203:191-97

KALAUNI, S. K., AWALE, S., TEZUKA, Y., BANSKOTA, A. H., LINN, T. Z., ASIH, P. B. S. \& KADOTA, S. 2006. Antimalarial activity of cassane-and norcassane-type diterpenes from Caesalpinia crista and their structure-activity relationship. Biological and Pharmaceutical Bulletin, 29(5), 1050-1052.

KAMILOVA, F., KRAVCHENKO, L. V., SHAPOSHNIKOV, A. I., AZAROVA, T., MAKAROVA, N., \& LUGTENBERG, B. 2006. Organic acids, sugars, and L-tryptophane in exudates of vegetables growing on stonewool and their effects on activities of rhizosphere bacteria. Molecular Plant-Microbe Interactions,19(3), 250-256.

KANNUR, D.M., HUKKERI, V.I., AKKI, K.S. 2006. Adaptogenic activity of Caesalpinia bonduc seed extracts in rats. Journal of Ethnopharmacology. 108: 327-331.

KATO-NOGUCHI, H., INO, T., SATA, N., \& YAMAMURA, S. 2002. Isolation and identification of a potent allelopathic substance in rice root exudates. Physiologia Plantarum, 115(3), 401-405.

KIDD, P., LLUGANY, M., POSChENRIEDER, C., GUNSÉ, B., \& BARCELÓ, J. (2001). Plants and the Environment. The role of root exudates in aluminium resistance and siliconinduced amelioration of aluminium toxicity in three varieties of maize ( Zea mays L.). Journal Of Experimental Botany, 52(359), 1339. 
KIM, Y.O.; JOHNSON, J.D. \& LEE, E.J. 2005. Phytotoxicity of Phytolacca Americana leaf extracts on the growth, and physiological response of Cassia mimosoides. Journal of Chemical Ecology 31: 2963-2974.

KINOSHITA, T. 2000. Chemical Studies on the Philippine Crude Drug Calumbibit (Seeds of Caesalpinia bonduc): The Isolation of New Cassane Diterpenes Fused with $\alpha, \beta-$ Butenolide. Chemical \& Pharmaceutical Bulletin, 48(9) 1375-1377

KINOSHITA, T., KANEKO, M., NOGUCHI, H., \& KITAGAWA, I. 1996. New cassane diterpenes from Caesalpinia bonduc (Fabaceae). Heterocycles, 2(43), 409-414.

KITAGAWA, I., SIMANJUNTAK, P., MAHMUD, T., KOBAYASHI, M., FUJII, S., UJI, T., \& SHIBUYA, H. 1996. Indonesian Medicinal Plants. XIII. Chemical Structures of Caesaldekarins c, d, and e, Three Additional Cassane-Type Furanoditerpenes from the Roots of Caesalpinia major (Fabaceae). Several Interesting Reaction Products of Caesaldekarin a Provided by N-Bromosuccinimide Treatment. Chemical and pharmaceutical bulletin, 44(6), 1157-1161.

KONG, C., LIANG, W., XU, X., HU, F., WANG, P., \& JIANG, Y. 2004. Release and activity of allelochemicals from allelopathic rice seedlings. Journal of agricultural and food chemistry, 52(10), 2861-2865.

LANKAU, R. 2010. Soil microbial communities alter allelopathic competition between Alliaria petiolata and a native species. Biological Invasions, 12(7), 2059-2068.

LesuffleuR, F., PAYNel, F., BATAille, M. P., Le DeUnFF, E., CliQuet, J. B. (2007): Root amino acid exudation: measurement of high efflux rates of glycine and serine from six different plant species. Plant Soil 294, 235-246.

LEWIS, G.P.; SCHRIRE, B.; MACKINDER, B. \& LOCK, M. 2005. Legumes of the world. Royal Botanic Gardens, Kew. 578p. 
LI, Z.-H., WANG, Q., RUAN, X., PAN, C.-D. AND JIANG, D.-A. 2010. Phenolics and Plant Allelopathy. Molecules, 15, 8933-8952.

LIU, W., HOU, J., WANG, Q., YANG, H., LUO, Y., \& CHRISTIE, P. (2015). Collection and analysis of root exudates of Festuca arundinacea $L$. and their role in facilitating the phytoremediation of petroleum-contaminated soil. Plant \& Soil, 389(1/2), 109-119.

LYDER, D.L.; PETER, S.R.; TINTO, W.F.; BISSADA, S.M.; MCLEAN, S.; REYNOLDS, W.F. 1998. Minor Cassane Diterpenoids of Caesalpinia bonduc. Journal of Natural Products.61(12): 1462-1465

MACÍAS, F. A., GARCíA-DÍAZ, M. D., JORRÍN, J., \& GALINDO, J. C. G. 2006. Playing with chemistry: studies on Orobanche spp. germination stimulants. In: Allelopathy (pp. 495-510). Springer Netherlands.

MACIAS, F.A., MOLINILLO, J.M.G.,VARELA, R.M., GALINDO, J.C.G. 2007. Allelopathy a natural alternative for weed control. Pest Management Science. 63: 327-348.

MANDAL, S. 2001. Allelopathic activity of root exudates from Leonurus sibiricus L.(Raktodrone). Weed Biology and Management, 1(3), 170-175.

MARASCHIN, M., \& VERPOORTE, R. 1999. Secondary metabolism engineering. Optimization of secondary metabolite production in plant cell cultures.Biotechnol. Sci. Dev, 10, 24-28.

MARSCHNER H. 1995 Mineral Nutrition of Higher Plants (Academic Press,London), Ed 2.

MARSCHNER, H. (1998): Role of root growth, arbuscular mycorrhiza, and root exudates for the efficiency in nutrient acquisition. Field Crops Res. 56, 203-207.

MARTINS, L.S.G. \& ALVES, R.J.V. 2007. Regeneração Natural do Morro Vermelho, Ilha da Trindade. Revista Brasileira de Biociências 5: 39-41. 
MURRELL, C., GERBER, E., KREBS, C., PAREPA, M., SCHAFFNER, U., \& BOSSDORF, O. 2011. Invasive knotweed affects native plants through allelopathy. American Journal of Botany, 98(1), 38-43.

NGUYEN, C. 2003. Rhizodeposition of organic C by plants: mechanisms and controls. Agronomie-Sciences des Productions Vegetales et de I'Environnement, 23(5-6), 375-396.

OGAWA, K., AOKI, I., SASHIDA, Y., 1992. Caesaljapin, a cassane diterpenoid from Caesalpinia decapetala var. japonica. Phytochemistry 31, 2897-2898.

OLIVEROS-BASTIDAS, A. J. 2008. El fenômeno alelopático. El concepto, lãs estratégias de estidio y su aplicacíon em La búsqueda de herbicidas naturales. Quimica Viva. (7)1:234.

OLIVEROS-BASTIDAS, A. J., MACIAS, F. A., FERNANDEZ, C. C., MARIN, D., MOLINILLO, J. M. G. 2009. Exudados de la raiz y su relevância actual en lãs interacciones alelopaticas. Quimica Nova, 32: 198-213.

PARK, S., TAKANO, Y., MATSUURA, H., \& YOSHIHARA, T. 2004. Antifungal compounds from the root and root exudate of Zea mays. Bioscience, biotechnology, and biochemistry, 68(6), 1366-1368.

PARVEZ, S. S., PARVEZ, M. M., FUJII, Y., \& GEMMA, H. 2003. Allelopathic competence of Tamarindus indica $L$. root involved in plant growth regulation. Plant growth regulation, 41(2), 139-148.

PASCOE, K. O.; BURKE, B. A.; CHAN, W. R. 1986. Caesalpin F: A new furanoditerpene from Caesalpinia bonducella. Journal of Natural Products, 49(5): 913-915

PAUL-VICTOR, C., ZÜST, T., REES, M., KLIEBENSTEIN, D. J., \& TURNBULL, L. A. (2010). A new method for measuring relative growth rate can uncover the costs of defensive compounds in Arabidopsis thaliana. New Phytologist, 187(4), 1102-1111. 
PELLISSIER, F. 2013. Improved germination bioassays for allelopathy research. Acta physiologiae plantarum, 35(1), 23-30.

PEÑUELAS, J., RIBAS-CARBO, M., \& GILES, L. 1996. Effects of allelochemicals on plant respiration and oxygen isotope fractionation by the alternative oxidase. Journal of Chemical Ecology, 22(4), 801-805.

PÉREZ, F. J., and ORMEÑO-NÚÑEZ , J. 1991. Difference in hydroxamic acid content in roots and root exudates of wheat (Triticum aestivum L.) and rye (Secale cereale L.): Possible role in allelopathy. J. Chem. Ecol. 17:1037-1043

PERRY IV, E.L.; DENNIS, J.V. 2003. Sea-Beans from the tropics: a collector's guide to sea-beans and other tropical drift on Atlantic shores. Krieger Publishing Company, 217.

PETER, S., TINTO, W.F., MCLEAN, S., REYNOLDS, W.F., YU, M., 1998. Cassane diterpenes from Caesalpinia bonducella. Phytochemistry 47, 1153-1155.

PETER, S.; TINTO, W.F.; McLEAN, S.; REYNOLDS, W.F.; TAY, L.L. 1997. Caesalpinin, a rearranged Cassane Furanoditerpene of Caesalpinia bonducella. Tetrahedron Letters, 38(3):5767-5770.

PHILIPPOT, L., RAAIJMAKERS, J. M., LEMANCEAU, P., \& VAN DER PUTTEN, W. H. 2013. Going back to the roots: the microbial ecology of the rhizosphere. Nature Reviews Microbiology, 11(11), 789-799.

PONCE, M. A., SCERVINO, J. M., ERRA-BALSELLS, R., OCAMPO, J. A., \& GODEAS, A. M. 2004. Flavonoids from shoots, roots and roots exudates of Brassica alba. Phytochemistry, 65(23), 3131-3134.

PUTNAM, A. R., \& TANG, C. S. 1986. The science of allelopathy. John Wiley \& Sons Inc. 
RASMANN, S., HILTPOLD, I., \& ALI, J. 2012. The role of root-produced volatile secondary metabolites in mediating soil interactions. In: Montanaro. G.; Dichio, B. Advances in Selected Plant. InTechTech Open Access Publisher. P. 398

REIGOSA, M. J, SÁNCHEZ-MOREIRAS, A., \& GONZÁLEZ, L. 1999. Ecophysiological approach in allelopathy. Critical Reviews in Plant Sciences, 18(5), 577-608.

REIGOSA, M.; GOMES, A.S.; FERREIRA, A.G.; BORGHETTI, F. 2013. Allelopathic research in Brazil. Acta Botanica Brasilica 27(4): 629-646

REZENDE, A.A.G., HERNANDEZ-TERRONES, G.M., REZENDE, C.L.M.D. 2011. Estudo do potencial alelopático do extrato metanólico de raiz e caule de Caryocar brasiliense Camb. (Pequi). Bioscience Journal (27)3: 460-472.

REZENDE, C.P.; PINTO, J.C.; EVANGELISTA, A.R.; SANTOS, I.P.A. 2003. Alelopatia e suas interações na formação e manejo de pastagens. Boletim agropecuário. Universidade Federal de Lavras. p.1-55.

RICE E.L. 1984. Allelopathy. 2nd edn. Academic Press, NY, USA.

RICE, E.L. 1974. Allelophaty. Physiological ecology. Academic Press.

ROUATT, J. W.; KATZNELSON, H. 1960. Influence of light on bacterial flora of roots. Nature 186, 659-660

RUDRAPPA, T.; BONSALL, J.; GALLAGAR, J.; SELISKAR, D.M.; BAIS, H.P. 2007. Root secreted allelochemical in noxious weed Phragmites australis deploys a reactive oxygen species response and microtubule assembly disruption to execute rhizotoxicity. Journal of Chemical Ecology 33: 1898-1918

SANDNES, A., ELDHUSET, T. D., \& WOLLEB/EK, G. 2005. Organic acids in root exudates and soil solution of Norway spruce and silver birch. Soil Biology and Biochemistry, 37(2), 259-269. 
SANTOS, C. A., PASSOS, A. M., ANDRADE, F. C., CAMARGO, E. A., ESTEVAM, C. S., SANTOS, M. R., \& THOMAZZI, S. M. (2011). Antinociceptive and anti-inflammatory effects of Caesalpinia pyramidalis in rodents. Revista Brasileira de Farmacognosia

SANTOS, J. C. F.; SOUSA, I. F.; MENDES, A. N. G.; MORAIS, A. R.; CONCEIÇÃO, H. E. O.; MARINHO, J. T. S. 2001. Influência alelopática das coberturas mortas de casca de café (Coffea arabica L.) e casca de arroz (Oryza sativa L.) sobre o controle do caruru-demancha (Amaranthus viridis L.) em lavoura de café. Ciência e Agrotecnologia, 25(5): 1105-1118.

SANTOS, L.S., SANTOS, J.C.L., SOUZA FILHO, A.P.S., CORRÊA, M.J.C., VEIGA, T.A.M., FREITAS, V.C.M., FERREIRA, I.C.S., GONÇALVES, N.S., SILVA, C.E. e GUILHON, G.M.S.P. 2008. Atividade alelopática de substâncias químicas isoladas do capim-marandu e suas variações em função do pH. Planta Daninha (26)3: 531-538.

SEAL, A. N., PRATLEY, J. E., HAIG, T., \& AN, M. 2004. Identification and quantitation of compounds in a series of allelopathic and non-allelopathic rice root exudates. Journal of chemical ecology, 30(8), 1647-1662.

SHARMA, S.R., DWIVEDI, S.K., SWARUP, D., 1997. Hypoglycaemic, antihyperglycaemic and hypolipidemic activities of Caesalpinia bonducella seeds in rats. J. Ethnopharm. 58, 39-44.

SILVA, N.G.; ALVES, R.J.V. 2011. The eradication of feral goats and its impact on plant biodiversity - a milestone in the history of Trindade Island, Brasil. Rodriguésia 62(3): 717719.

SIMIN, K., KHALIQ-UZ-ZAMAN, S.M., AHMAD, V.U. 2001. Antimicrobial activity of seed extracts and bondenolide from Caesalpinia bonduc (L.) Roxb. Phytotherapy Research, 15, 437-440.

SINGH, B. K., NAZARIES, L., MUNRO, S., ANDERSON, I. C., \& CAMPBELL, C. D. 2006. Use of Multiplex Terminal Restriction Fragment Length Polymorphism for Rapid and 
Simultaneous Analysis of Different Components of the Soil Microbial Community ${ }^{\nabla}$. Applied and Environmental Microbiology, 72(11), 7278-7285.

SKOOG, D.A.; HOLLER, F.J.; NIEMAN, T.A. 2002. Principios de analise instrumental. 5ed. Porto Alegre: Bookman (SBQ). 598-676.

Sociedade Internacional de Alelopatia. 2012. Disponível em: http://www.internationalallelopathy-society.org. Acesso em: 26 dez 2013

SOUZA FILHO, A. P. S., \& DUARTE, M. L. R. 2007. Atividade alelopática do filtrado de cultura produzido por Fusarium solani. Planta Daninha, 25(1), 227-230.

STERMITZ, F. R., BAIS, H. P., FODERARO, T. A., \& VIVANCO, J. M. 2003. RETRACTED: 7, 8-Benzoflavone: a phytotoxin from root exudates of invasive Russian knapweed. Phytochemistry, 64(2), 493-497.

SUNITA, S.; SMRUTI, S.; NEELAM, S. 2010. HPTLC method development and validation of a secondary metabolite $\beta$ sitosterol from Caesalpinia bonduc (Linn.) Roxb. Emend. Dandy \& Exell. Sedds. International jornal of Pharma and Bio Sciences. 1:1-10.

TAIZ, L.; ZEIGER, E. 2009. Fisiologia vegetal. 4 ed. Porto Alegre: Artmed, 719 p.

TEERARAK, M.; ChAROENYING, P., \& LAOSInWATtANA, C. 2012. Physiological and cellular mechanisms of natural herbicide resource from Aglaia odorata Lour. on bioassay plants. Acta physiologiae plantarum, 34(4), 1277-1285.

THELEN, G. C., VIVANCO, J. M., NEWINGHAM, B., GOOD, W., BAIS, H. P., LANDRES, P., \& CALLAWAY, R. M. 2005. Insect herbivory stimulates allelopathic exudation by an invasive plant and the suppression of natives. Ecology Letters, 8(2), 209-217.

THORPE, A. S., THELEN, G. C., DIACONU, A., \& CALLAWAY, R. M. 2009. Root exudate is allelopathic in invaded community but not in native community: field evidence for the novel weapons hypothesis. Journal of Ecology, 97(4), 641-645. 
TILMAN, D. 1986. Resources, competition and the dynamics of plant

UDDIN, M. R., PARK, S. U., DAYAN, F. E., \& PYON, J. Y. 2014. Herbicidal activity of formulated sorgoleone, a natural product of sorghum root exudate. Pest management science, 70(2), 252-257.

UREN, N.C. 2000. Types, amounts and possible functions of compounds released into the rhizosphere by soil grown plants. In The Rhizosphere: Biochemistry and Organic Substances at the Soil Interface, ed. R Pinton, Z Varanini, P Nannipieri. pp. 19-40. New York: Marcel Dekker

VIEGAS JÚNIOR, C. 2003. Terpenes with insecticidal activity: an alternative to chemical control of insects. Química Nova, 26(3), 390-400.

WANG, J.; LI, X.; ZHANG, J.; YAO, T.; WEI. D.; WANG, Y.; WANG, J. 2012. Effect of root exudates on beneficial microorganisms- evidence from a continuous soybean monoculture. Plant Ecology. 213:1883-1892

WANG, Q.; LIU, Y.; CUI, J; DU, J.; CHEN G,; LIU, H. 2011. Optimization of ultrasonicassisted extraction for herbicidal activity of chicory root extracts. Industrial Crops and Products, 34: 1429- 1438.

WARDLE DA, LAVELLE P. 1997. Linkages between soil biota, plant litter quality, and decomposition. In Driven by Nature, Plant Litter Quality and Decomposition, ed. G Cadisch, KE Giller, pp. 107-24.Wallingford: CAB Intl.

WEIR, T.L.; BAIS, H.P.; VIVANCO, J.M. 2003. Intraspecific and interspecific interactions mediated by a phytotoxin, (-)-catechin, secreted by the roots of Centaurea maculosa (spotted knapweed). Journal Chemical Ecology 29:2397-412

WEIR, T.L.; PARK, S.W. VIVANCO, J.M. 2004. Biochemical and physiological mechanisms mediated by allelochemicals. Current Opinion in Plant Biology. 7:472-479. 
WHIPPS, J. M.1990. Carbon economy. The rhizosphere., 59-97.

WHITTAKER, R. H., \& FEENY, P. P. (1971). Allelochemics: chemical interactions between species. Science, (171), 757-70.

WINK, W. 2010. Introduction: Biochemistry, physiology and ecological functions of secondary metabolites. In: WINK, W. Biochemistry of plant secondary metabolism. 2Ed. John Wiley \& Sons Ltd. 2010. p. 1-19.

WU, H., HAiG, T. PRATLEY, J. LEMERLE, D. \& AN, M. 2001. Allelochemicals in wheat (Triticum aestivum L.): production and exudation of 2, 4-dihydroxy-7-methoxy-1, 4benzoxazin-3-one. Journal of chemical ecology, 27(8), 1691-1700.

YADAV, P. P., MAURYA, R., SARKAR, J., ARORA, A., KANOJIYA, S., SINHA, S., SRIVASTAVA, M.N.; RAGHUBIR, R. 2009. Cassane Diterpenes from Caesalpinia bonduc. Phytochemistry, 70(2): 256-261.

YOSHIMURA, H., SAWAI, Y., TAMOTSU, S., \& SAKAI, A. 2011. 1, 8-cineole inhibits both proliferation and elongation of BY-2 cultured tobacco cells.Journal of chemical ecology, 37(3), 320-328.

ZAHEDI, S. M., \& ALEMZADEH ANSARI, N. 2011. Allelopathic potential of common mallow (Malva sylvestris) on the germination and the initial growth of tomato, cucumber and cress. Asian Journal of Agricultural Sciences, 3(3), 235-241.

ZHANG, C.; FU, S. 2010. Allelopathic effects of leaf litter and live roots exudates of Eucalyptus species on crops. Allelopathy Journal 26 (1): 91-100

ZHANG, F., MENG, X., YANG, X., RAN, W., \& SHEN, Q. 2014. Quantification and role of organic acids in cucumber root exudates in Trichoderma harzianum T-E5 colonization. Plant Physiology and Biochemistry, 83, 250-2 


\section{Anexos}

Tabela 4. Espectros de absorção em UV-Vis $280 \mathrm{~nm}$, tempo de retenção, e pureza do pico obtidos dos extratos aquoso e metanólico e exsudado radicular de Guilandina bonduc L. 


\section{롤}

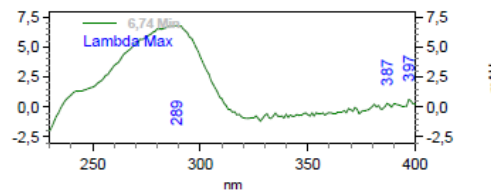

Tempo de retenção: 6,740 Min

Lambda máx: 289, 397, 387

Lambda min: 353, 333, 328

Pureza do pico: 0,878746

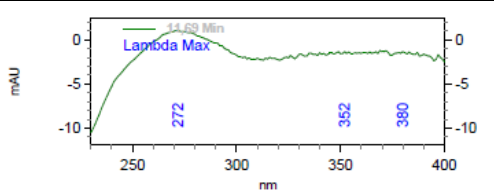

Tempo de retenção: 11,693 Min

Lambda máx: 272, 380, 352

Lambda min: 321, 313, 339

Pureza do pico: 0,471302

초ํ

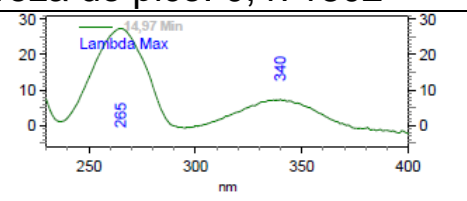

Tempo de retenção: 14,967 Min

Lambda máx: 265, 340

Lambda min: 295, 237

Pureza do pico: 0,981566

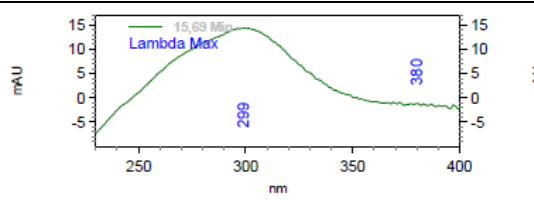

Tempo de retenção: 15,687 Min

Lambda máx: 299, 380

Lambda min: 374

Pureza do pico: 0,948327

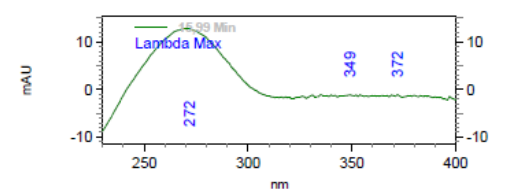

Tempo de retenção: 15,993 Min

Lambda máx: 272, 349, 372

Lambda min: 321, 343, 374

Pureza do pico: 0,894971

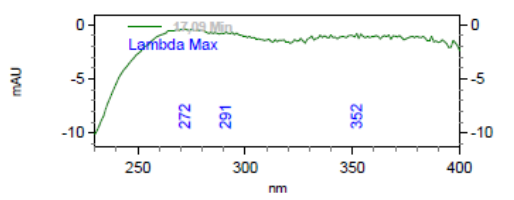

Tempo de retenção: 17,093 Min

Lambda máx: 272, 352, 291

Lambda min: 321, 374, 343

Pureza do pico: 0,164223

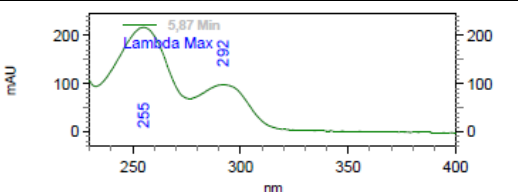

Tempo de retenção: 5,873 min

Lambda máx: 255, 292

Lambda min: 276, 233

Pureza do pico: 1,000000

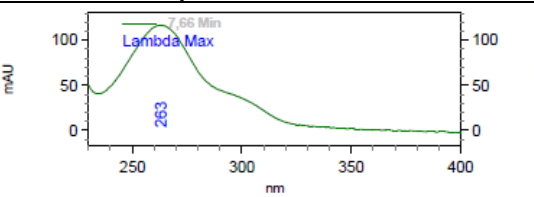

Tempo de retenção: 7,660 Min

Lambda máx: 263

Lambda min: 234

Pureza do pico: 0,818964

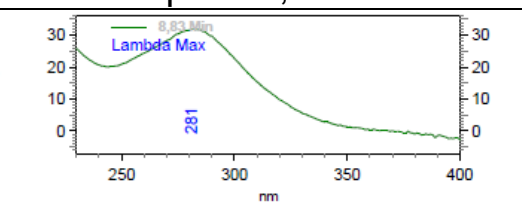

Tempo de retenção: 8,827 Min

Lambda máx: 281

Lambda min: 244

Pureza do pico: 0,526819

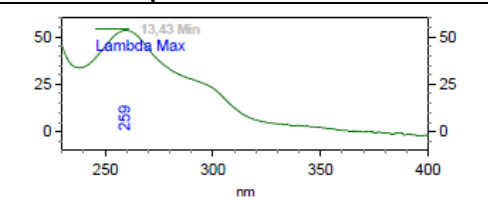

Tempo de retenção: 13,427 Min

Lambda máx: 259

Lambda min: 238

Pureza do pico 1,000000

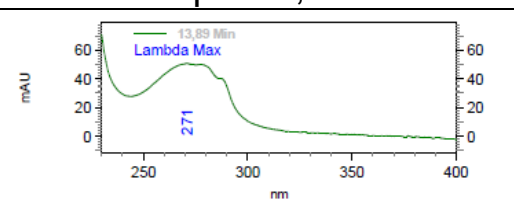

Tempo de retenção: 13,887 Min

Lambda máx: 271

Lambda min: 244

Pureza do pico: 0,855323

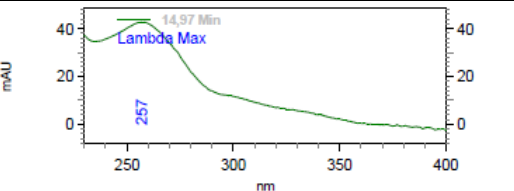

Tempo de retenção: 14,967 Min

Lambda máx: 257

Lambda min: 235

Pureza do pico: 0,918092

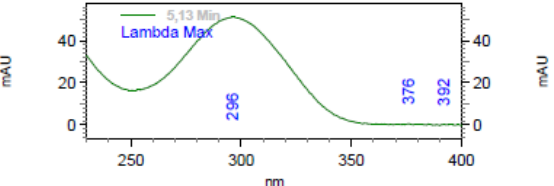

Tempo de retenção: 5,127 Min Lambda máx: 296, 392, 376 Lambda min: 390, 384, 374

Pureza do pico: 0,537644

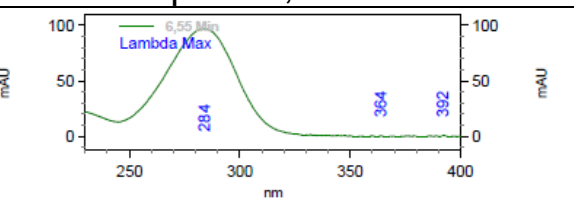

Tempo de retenção: 6,553 Min Lambda máx: 284, 392, 364

Lambda min: 388, 369, 378

Pureza do pico: 0,982277

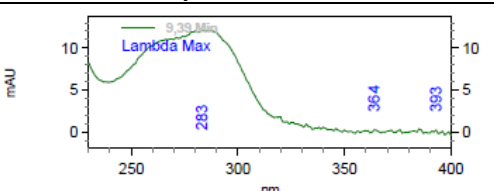

Tempo de retenção: 9,387 Min

Lambda máx: 283, 393, 364

Lambda min: 355, 367, 377

Pureza do pico: 0,391886

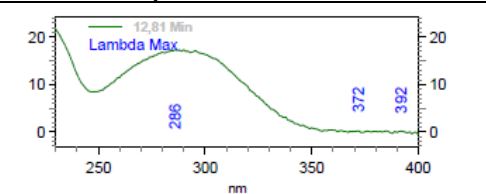

Tempo de retenção: 12,807 Min

Lambda máx: 286, 372, 392

Lambda min: 367, 378, 388

Pureza do pico: 0,662501

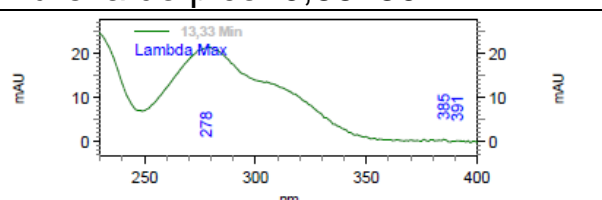

Tempo de retenção: 13,333 Min

Lambda máx: 278, 385, 391

Lambda min: 388, 367, 378

Pureza do pico: 0,721559

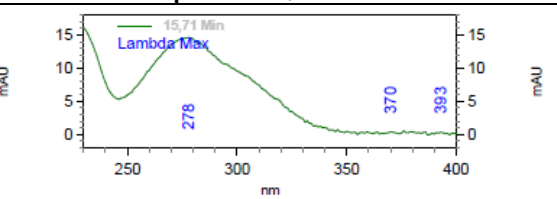

Tempo de retenção: 15,713 Min

Lambda máx: 278, 393, 370

Lambda min: 387, 365, 355

Pureza do pico: 0,938988 


\section{Exsudado radicular}

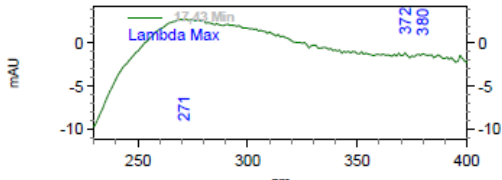

Tempo de retenção: 17,433 Min Lambda máx: 271, 380, 372

Lambda min: 374,366

Pureza do pico: 0,761063

골

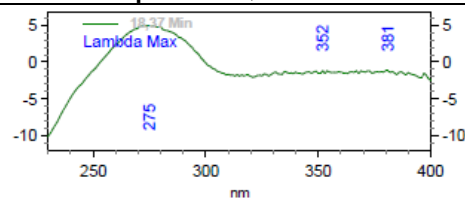

Tempo de retenção: 18,373 Min

Lambda máx: 275, 381, 352

Lambda min: 321, 363, 353

Pureza do pico: 0,976315

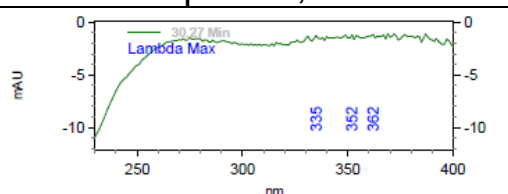

Tempo de retenção: 30,273 Min

Lambda máx: 352, 335, 362

Lambda min: 313, 315, 288

Pureza do pico: 0,157463

초ํ

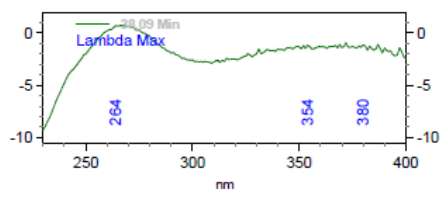

Tempo de retenção: 38,093 Min

Lambda máx: 264, 354, 380

Lambda min: 309, 356, 377

Pureza do pico: 0,878077

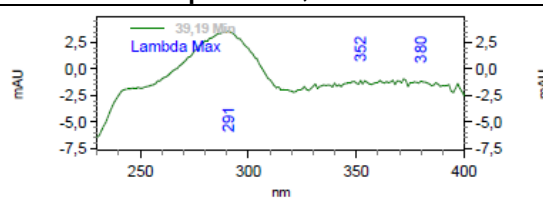

Tempo de retenção: 39,193 Min

Lambda máx: 291, 352, 380

Lambda min: 321, 357, 339

Pureza do pico: 0,972454

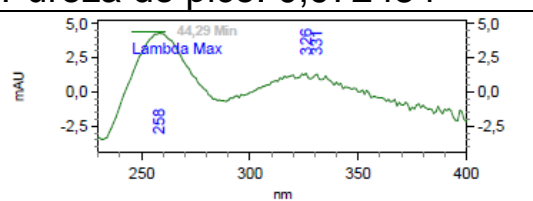

Tempo de retenção: 44,293 Min

Lambda máx: 258, 326, 331

Lambda min: 232, 389, 374

Pureza do pico: 1,000000

\section{Extrato aquoso}

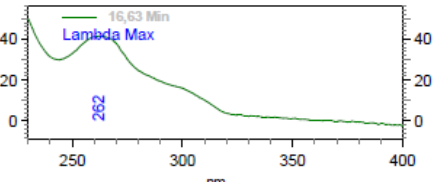

Tempo de retenção: 16,633 Min

Lambda máx: 262

Lambda min: 244

Pureza do pico: 0,887672

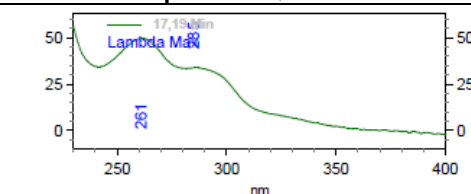

Tempo de retenção: 17,193 Min

Lambda máx: 261, 285

Lambda min: 280, 241

Pureza do pico: 0,904477

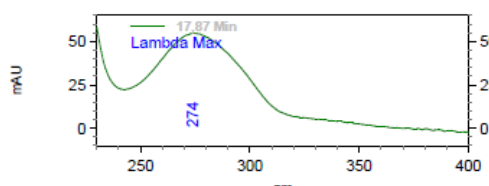

Tempo de retenção: 17,873 Min

Lambda máx: 274

Lambda min: 242

Pureza do pico: 0,716031

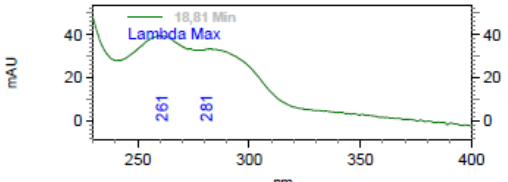

Tempo de retenção: 18,807 Min

Lambda máx: 261, 281

Lambda min: 241, 277

Pureza do pico: 0,936914

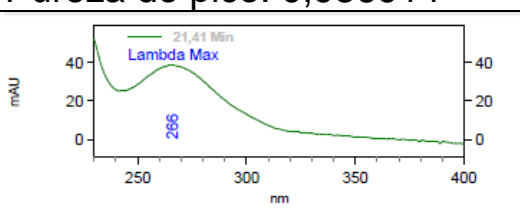

Tempo de retenção: 21,407 Min

Lambda máx: 266

Lambda min: 243

Pureza do pico: 0,95208

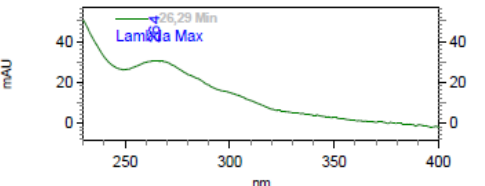

Tempo de retenção: 26,293 Min

Lambda máx: 264

Lambda min: 249

Pureza do pico: 0,880644
Extrato metanólico

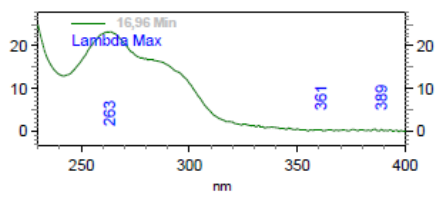

Tempo de retenção: 16,960 Min

Lambda máx: 263, 361, 389

Lambda min: 390, 362, 374

Pureza do pico: 0,794765

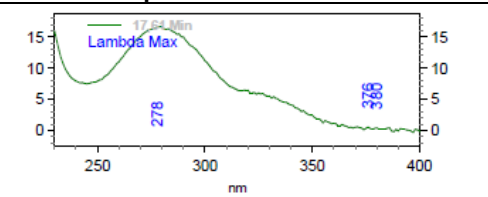

Tempo de retenção: 17,613 Min

Lambda máx: 278, 376, 380

Lambda min: 388, 374, 378

Pureza do pico: 0,574816

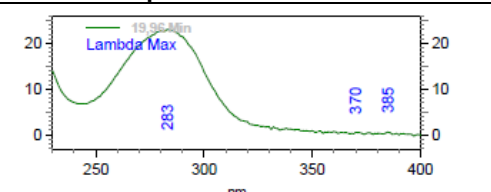

Tempo de retenção: 19,960 Min

Lambda máx: 283, 370, 385

Lambda min: 369, 390, 378

Pureza do pico: 0,861859

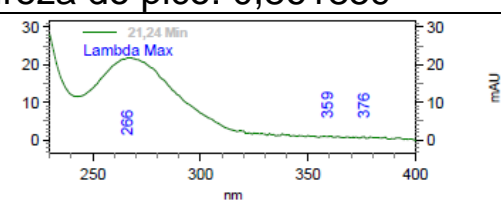

Tempo de retenção: 21,240 Min

Lambda máx: 266, 359, 376

Lambda min: 377, 367, 374

Pureza do pico: 0,942100

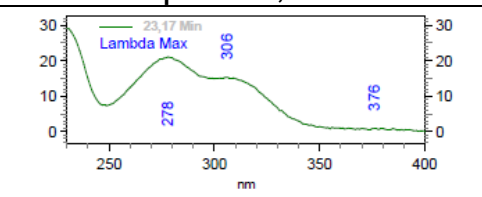

Tempo de retenção: 23,167 Min

Lambda máx: 278, 306, 376

Lambda min: 382, 374, 378

Pureza do pico: 0,784500

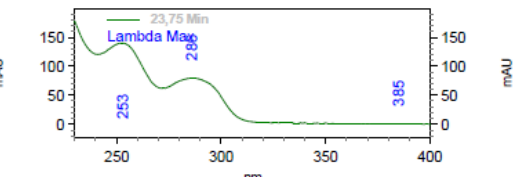

Tempo de retenção: 23,753 Min

Lambda máx: 253, 286, 385

Lambda min: 378, 388, 374

Pureza do pico: 1,000000 


\section{Exsudado radicular}

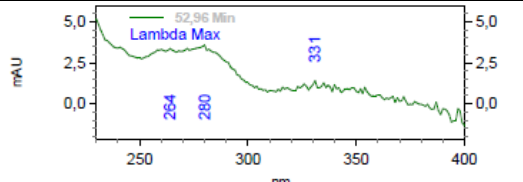

Tempo de retenção: 52,960 Min Lambda máx: 280, 264, 331 Lambda min: 309, 321, 315 Pureza do pico: 0,666821

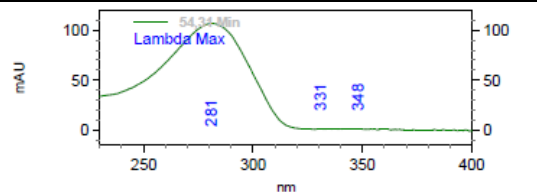

Tempo de retenção: 54,307 Min Lambda máx: 281, 331, 348 Lambda min: $376,353,347$ Pureza do pico: 0,716326

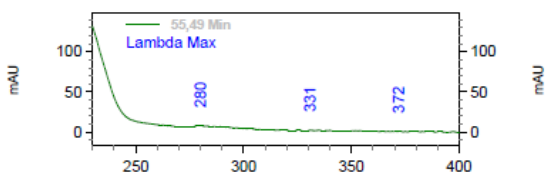

Tempo de retenção: 55,493 Min Lambda máx: 280, 331, 372 Lambda min: 395, 368, 374 Pureza do pico: 0,668530

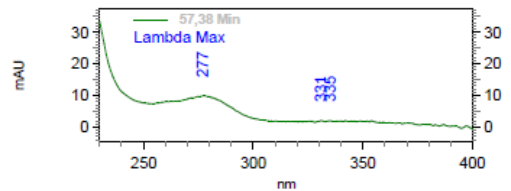

Tempo de retenção: 57,380 Min Lambda máx: 277, 331, 335 Lambda min: $321,341,333$ Pureza do pico: 0,427381

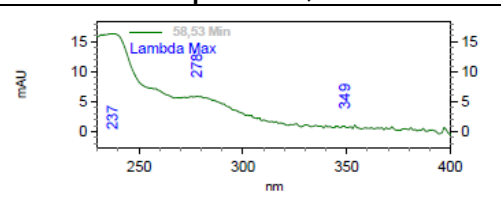

Tempo de retenção: 58,527 Min Lambda máx: 237, 278, 349 Lambda min: 395, 368, 374 Pureza do pico: 0,901023

\section{Extrato aquoso}

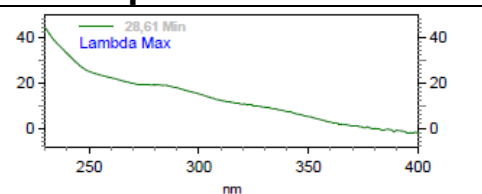

Tempo de retenção: $28,613 \mathrm{Min}$ Pureza do pico: 0,434330

\section{Extrato metanólico}

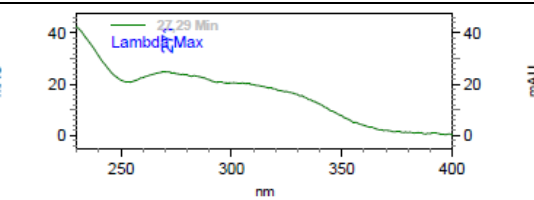

Tempo de retenção: 27,287 Min Lambda máx: 271 Lambda min: 252

Pureza do pico: 0,306729

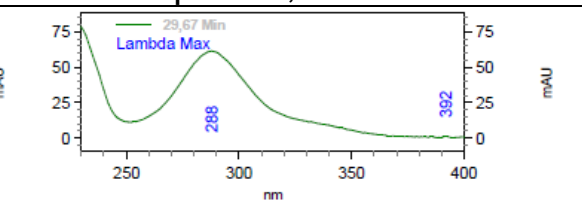

Tempo de retenção: 29,913 Min Lambda máx: 266

Lambda min: 252

Pureza do pico: 0,510909

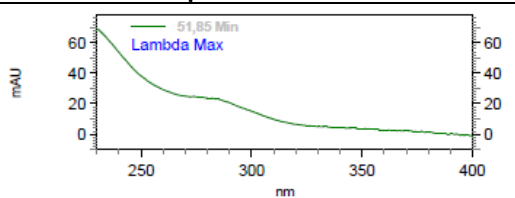

Tempo de retenção: 51,853 Min Pureza do pico: 0,611690

Tempo de retenção: 29,667 Min Lambda máx: 288, 392

Lambda min: 388, 252

Pureza do pico: 1,000000

$\underbrace{250}_{250}$

Tempo de retenção: 33,067 Min Lambda máx: 253, 288, 340 Lambda min: 315, 273, 245 Pureza do pico: 0,488331

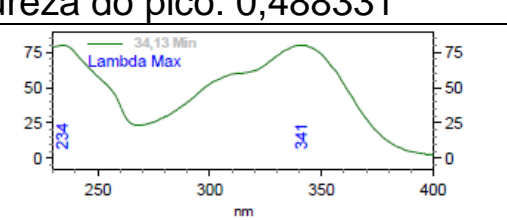

Tempo de retenção: 52,667 Min Pureza do pico: 0,946001
Tempo de retenção: 34,133 Min Lambda máx: 341, 234

Lambda min: 268

Pureza do pico: 1,000000
Tempo de retenção: 54,160 Min Lambda máx: 274

Lambda min: 272 Pureza do pico: 0,136584

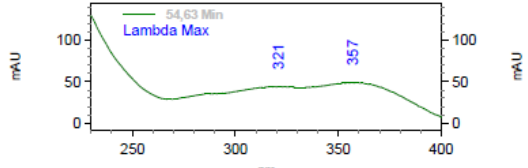

Tempo de retenção: 54,633 Min Lambda máx: 357, 321

Lambda min: 268, 330 Pureza do pico: 0,874996

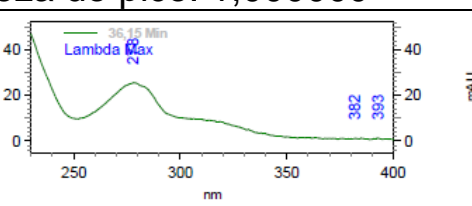

Tempo de retenção: 36,147 Min Lambda máx: 278, 393, 382 Lambda min: 389, 381, 374 Pureza do pico: 0,796891

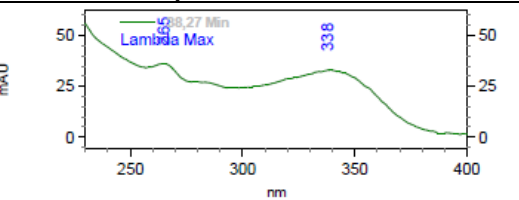

Tempo de retenção: 38,267 Min Lambda máx: 265, 338 Lambda min: 296, 257 Pureza do pico: 0,740645 


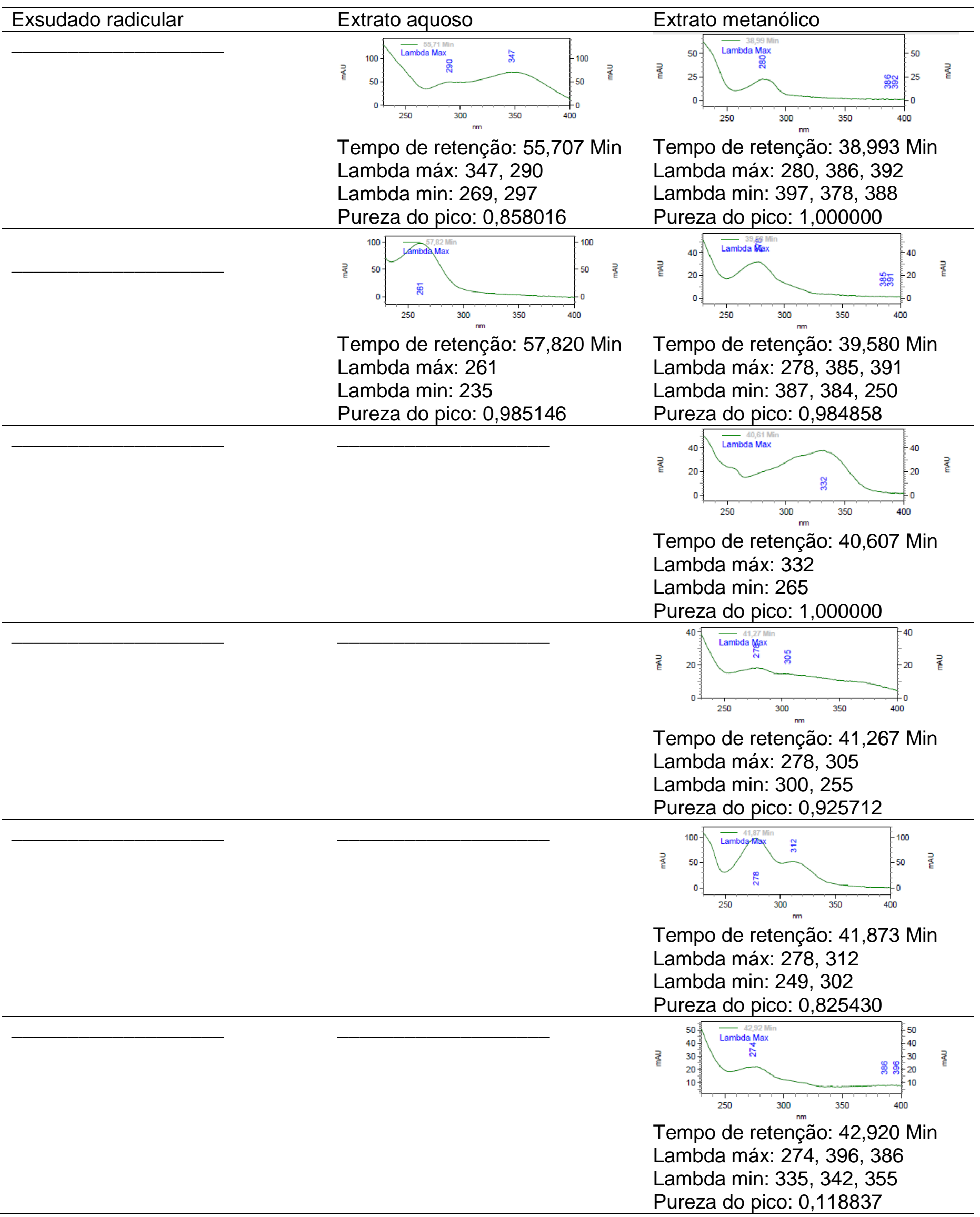




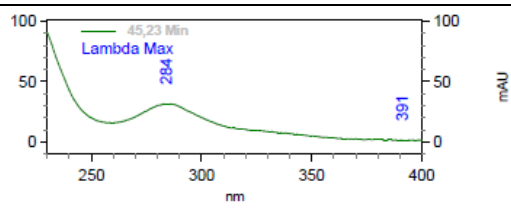

Tempo de retenção: 45,227 Min

Lambda máx: 284, 391

Lambda min: 390, 260

Pureza do pico: 0,868317

골

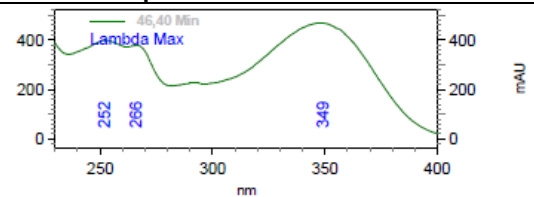

Tempo de retenção: 46,400 Min

Lambda máx: 349, 252, 266

Lambda min: 282, 297, 236

Pureza do pico: 1,000000

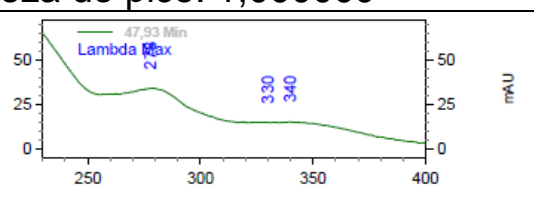

Tempo de retenção: 47,927 Min Lambda máx: 278, 340, 330

Lambda min: 321, 331, 255

Pureza do pico: 0,253482

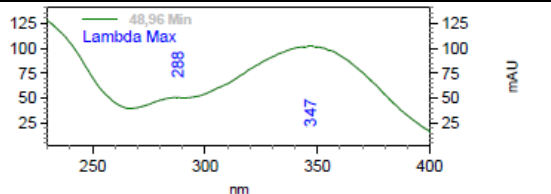

Tempo de retenção: 48,960 Min Lambda máx: 347, 288

Lambda min: 267, 293

Pureza do pico: 0,659002

촐

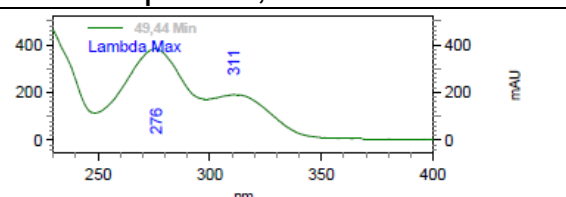

Tempo de retenção: 49,440 Min Lambda máx: 276, 311

Lambda min: 249, 298

Pureza do pico: 1,000000

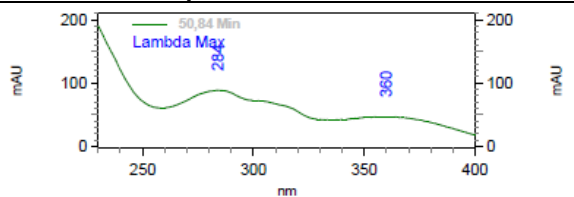

Tempo de retenção: 50,840 Min

Lambda máx: 284, 360

Lambda min: 335, 258

Pureza do pico: 0,219602 

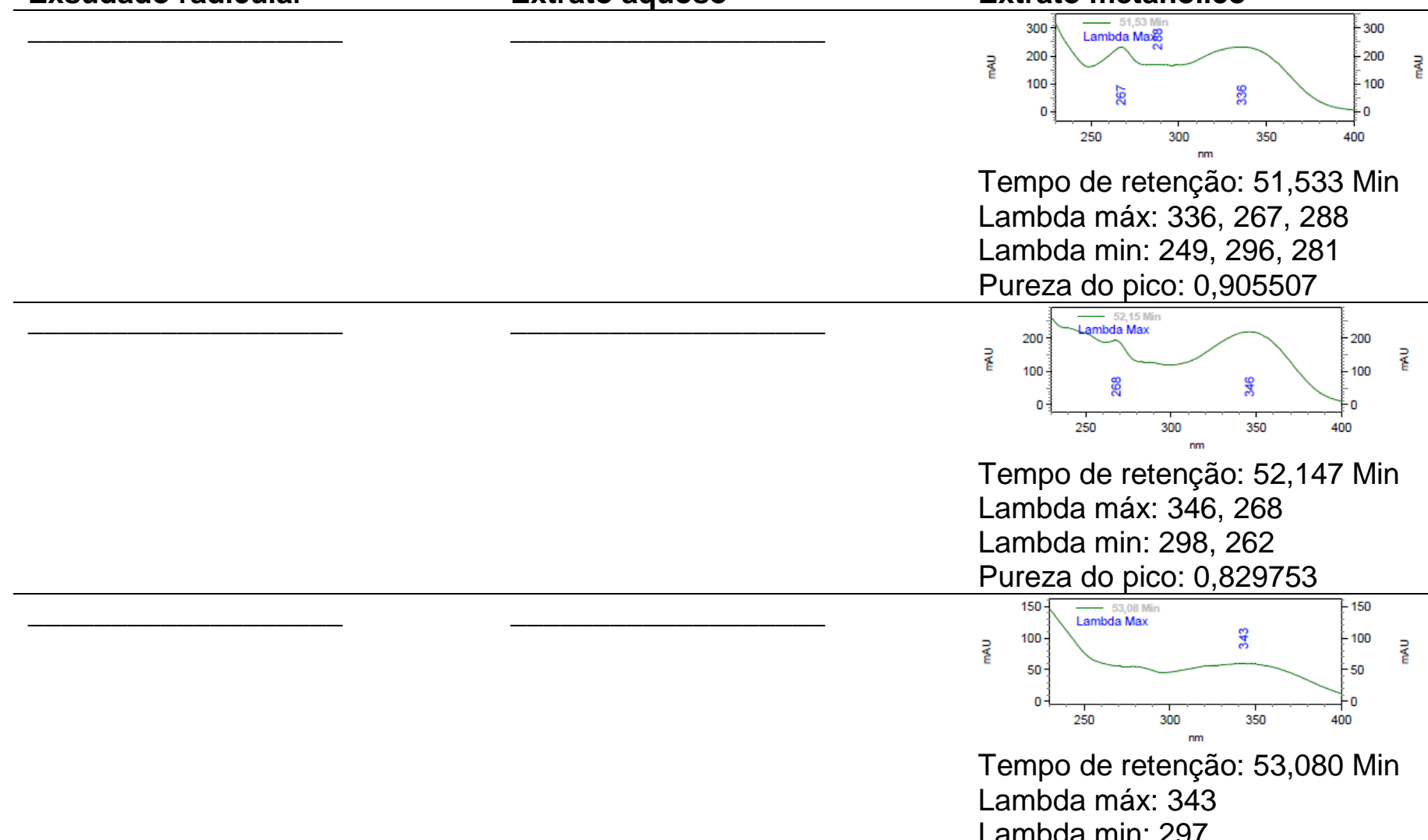

Tempo de retenção: 51,533 Min Lambda máx: 336, 267, 288

Lambda min: 249, 296, 281

Pureza do pico: 0,905507

로

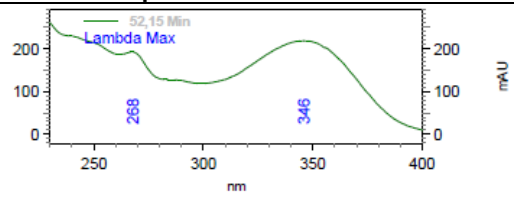

Tempo de retenção: 52,147 Min

Lambda máx: 346, 268

Lambda min: 298, 262

Pureza do pico: 0,829753

है

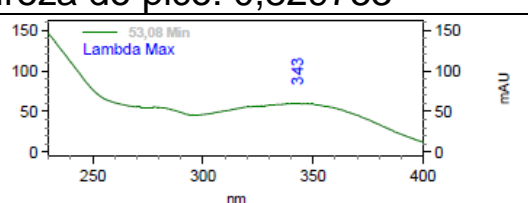

Tempo de retenção: 53,080 Min Lambda máx: 343

Lambda min: 297

Pureza do pico: 0,982891

골

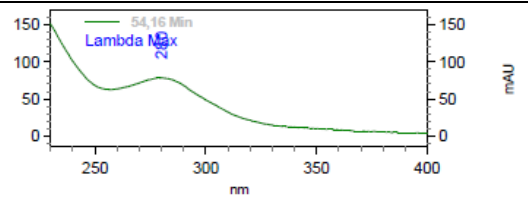

Tempo de retenção: 54,160 Min Lambda máx: 280

Lambda min: 257

Pureza do pico: 0,402443

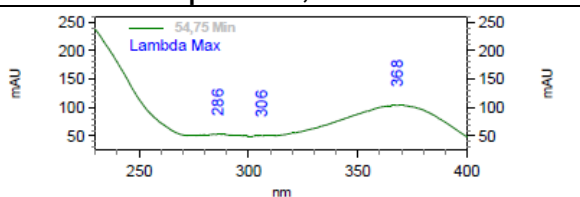

Tempo de retenção: 54,747 Min Lambda máx: 368, 286, 306 Lambda min: 300, 311, 275

Pureza do pico: 0,367777

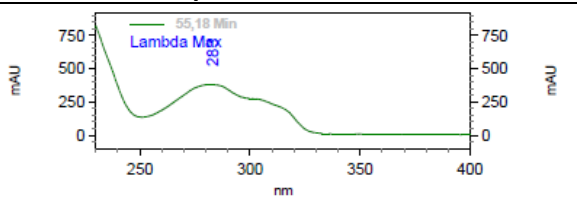

Tempo de retenção: 55,180 Min Lambda máx: 283

Lambda min: 251

Pureza do pico: 0,994702 
Tabela 5. . Espectros de absorção em UV-Vis 354nm, tempo de retenção, e pureza do pico obtidos dos extratos aquoso e metanólico e exsudado radicular de Guilandina bonduc L

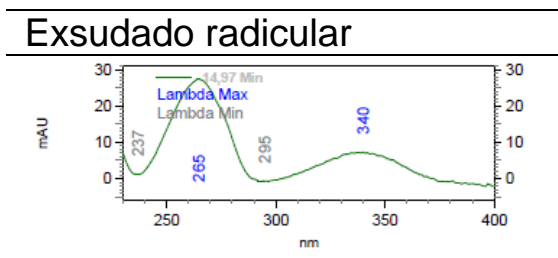

Tempo de retenção:14,967Min Lambda máx: 265,340

Lambda min: 295, 237

Pureza do pico: 0,959479

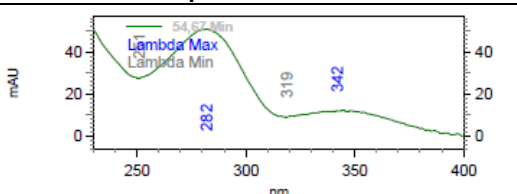

Tempo de retenção:54,667Min Lambda máx: 282, 342

Lambda min: 319,251

Pureza do pico: 0,464151

\section{Extrato aquoso}

궅뤁 굴

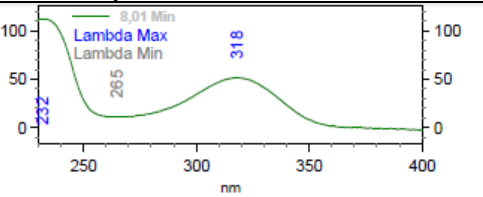

Tempo de retenção: 8,007 Min

Lambda máx: 232, 318

Lambda min: 265

Pureza do pico: 0,859821
Extrato metanólico

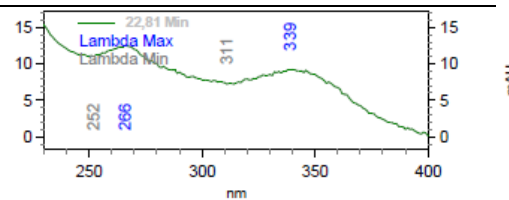

Tempo de retenção:22,807Min

Lambda máx: 266, 339

Lambda min: 311, 252

Pureza do pico: 0,562149
골

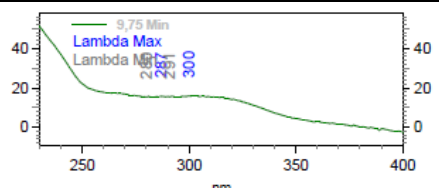

Tempo de retenção: 9,747 Min

Lambda máx: 300, 287

Lambda min: 280, 291

Pureza do pico: 0,174971

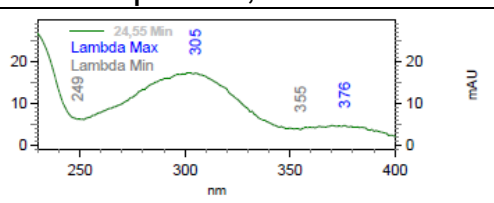

Tempo de retenção:24,553Min

Lambda máx: 305,376

Lambda min: 355, 249

Pureza do pico: 0,807576

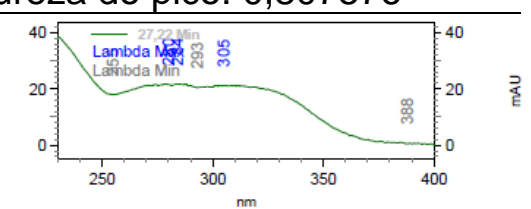

Tempo de retenção:27,220Min

Lambda máx: 284, 280, 305

Lambda min: 388, 255, 293

Pureza do pico: 0,337548

곹 곹

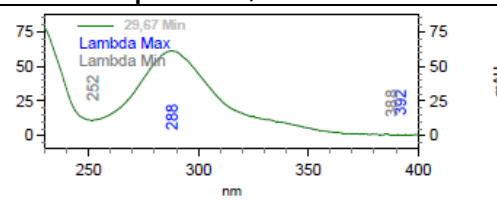

Tempo de retenção:29,673Min

Lambda máx: 288, 392

Lambda min: 388, 252

Pureza do pico: 1,000000

Pureza do pico: 0,601787

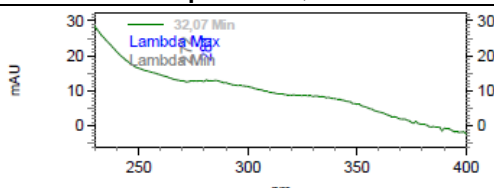

Tempo de retenção:32,067Min

Lambda máx: 281

Lambda min: 272

Pureza do pico: 0,840713

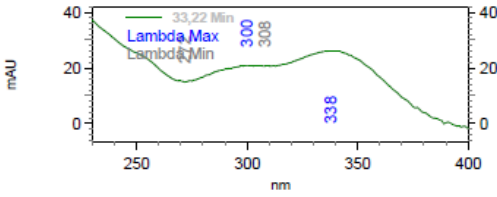

Tempo de retenção:

33,220Min

Lambda máx: 338, 300

Lambda min: 272, 308

Pureza do pico: 0,945137

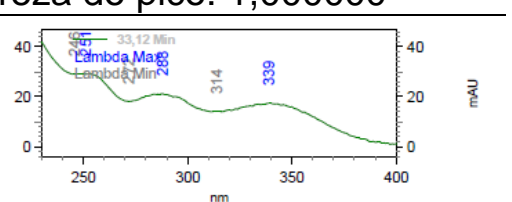

Tempo de retenção:33,120Min

Lambda máx: 251, 288, 339

Lambda min: 314, 272, 246

Pureza do pico: 0,476249

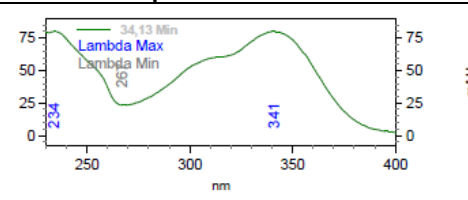

Tempo de retenção: 34,127Min

Lambda máx: 341, 234

Lambda min: 267

Pureza do pico: 0,929947 
Extrato aquoso

२ุ

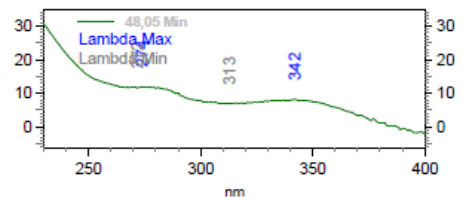

Tempo de retenção:48,047 Min Lambda máx: 274, 342

Lambda min: 313, 272

Pureza do pico: 0,753656

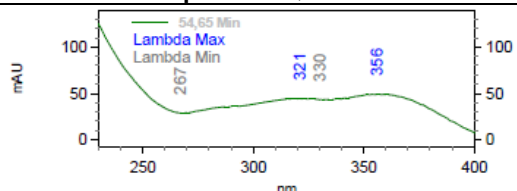

Tempo de retenção:54,647 Min Lambda máx: 356, 321

Lambda min: 267, 330

Pureza do pico: 0,577907

곹

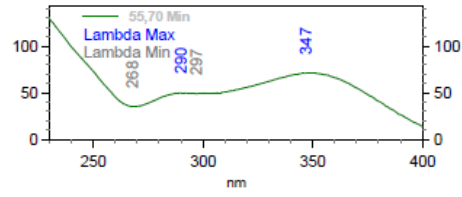

Tempo de retenção:55,700 Min Lambda máx: 347, 290

Lambda min: 268, 297

Pureza do pico: 0,975822
Extrato metanólico

골랕

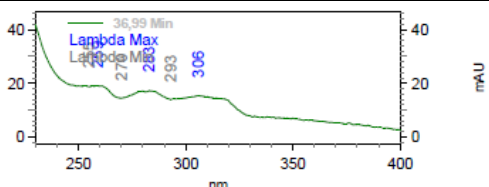

Tempo de retenção: 36,993 Min

Lambda máx: 259, 283, 306

Lambda min: 293, 270, 255

Pureza do pico: 0,373952

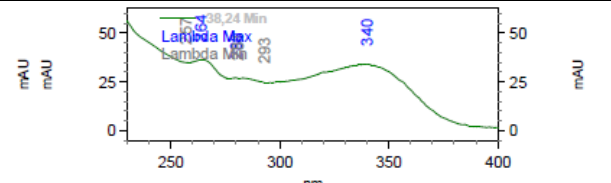

Tempo de retenção: 38,240 Min Lambda máx: 264, 340, 280

Lambda min: 293, 281, 257

Pureza do pico: 0,750730

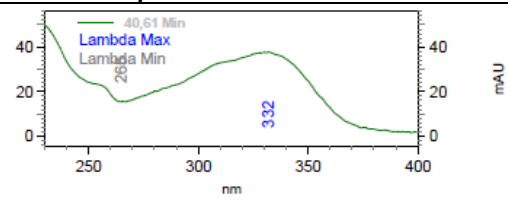

Tempo de retenção: 40,613 Min

Lambda máx: 332

Lambda min: 265

Pureza do pico: 0,941659

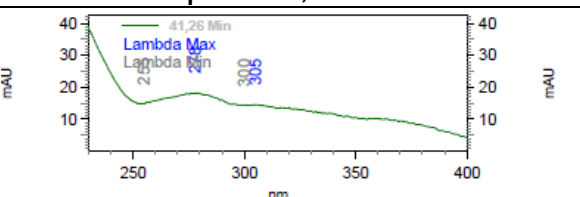

Tempo de retenção: 41,260 Min Lambda máx: 278, 305

Lambda min: 300, 255

Pureza do pico: 0,728103

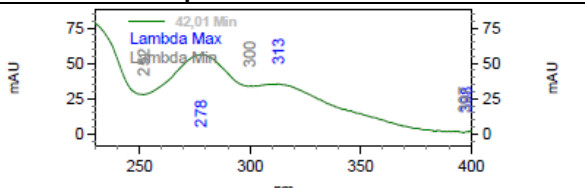

Tempo de retenção: 42,007 Min Lambda máx: 278, 313, 398

Lambda min: 397, 252, 300

Pureza do pico: 0,428770

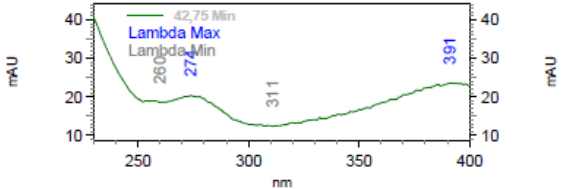

Tempo de retenção: 42,747 Min

Lambda máx: 391, 274

Lambda min: 311, 260

Pureza do pico: 0,741864 


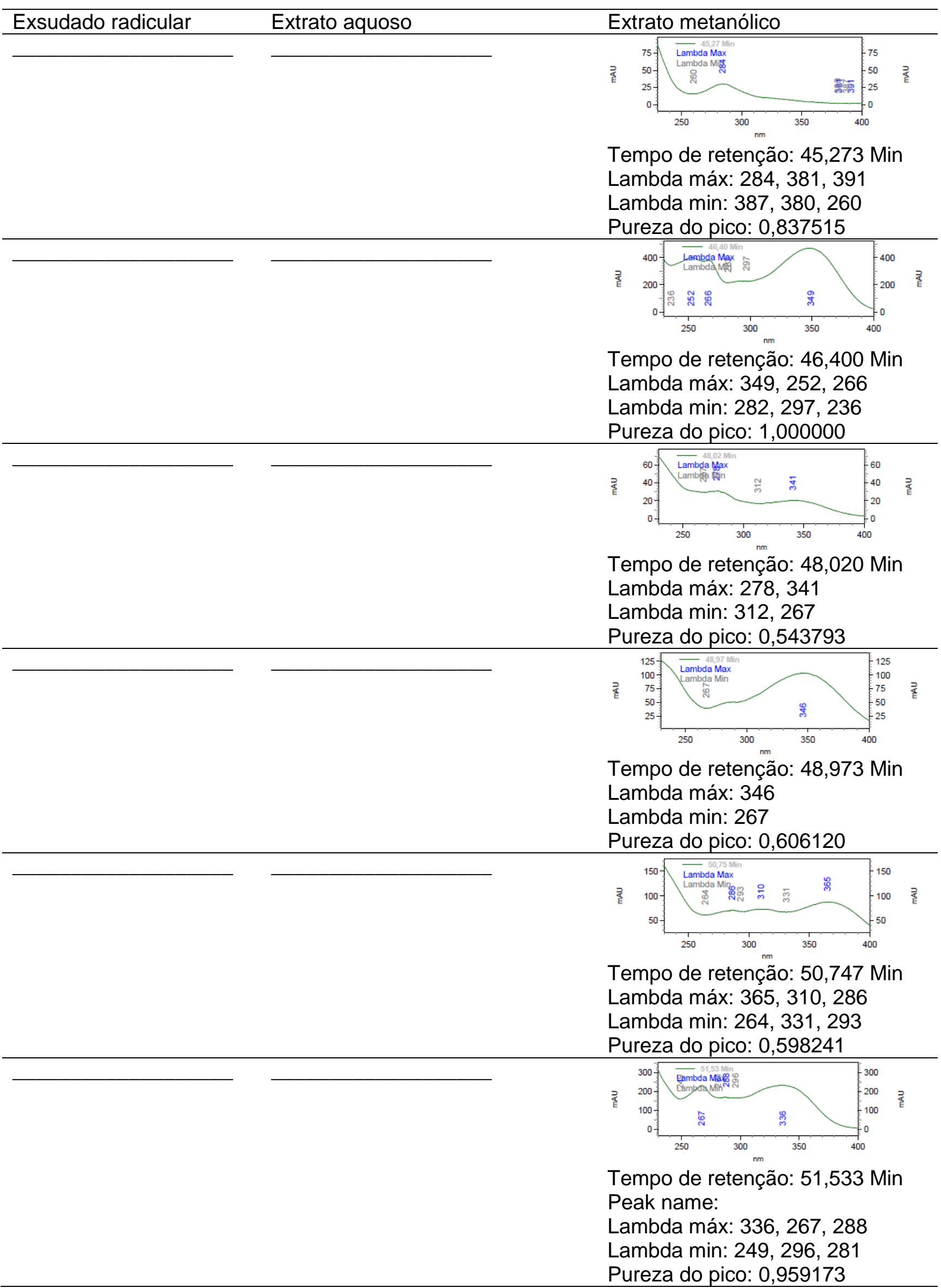




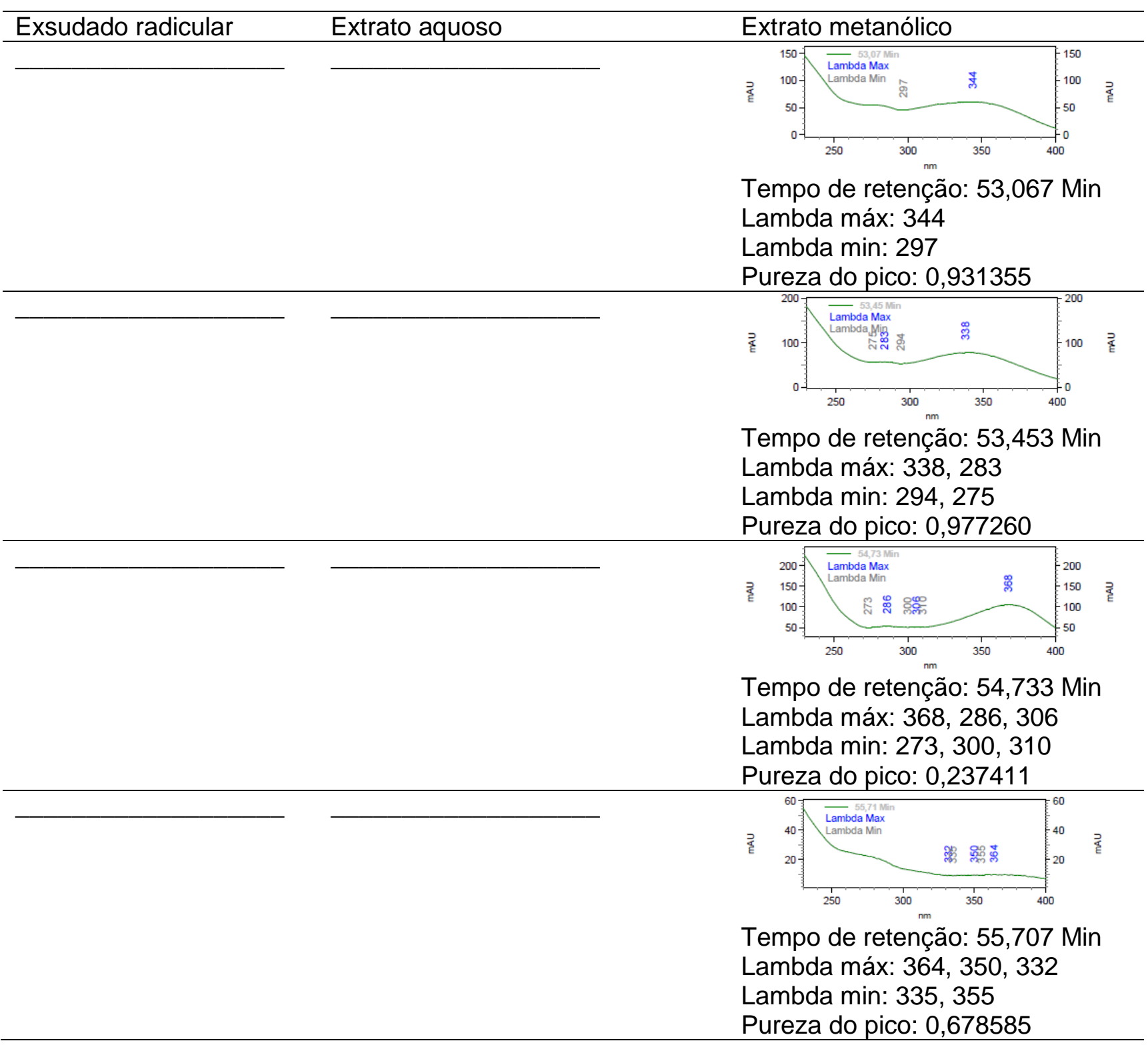




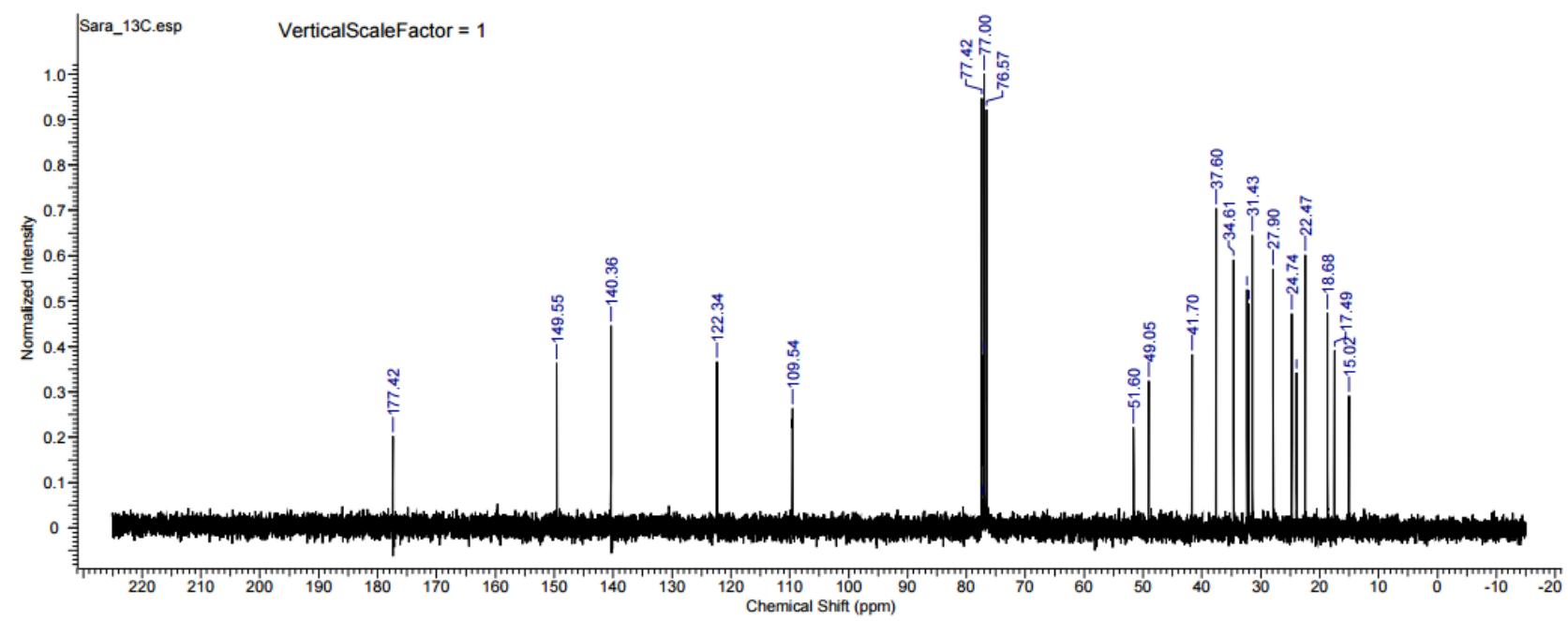

Figura 20. Espectro de $\mathrm{RMN}{ }^{13} \mathrm{C}$ de Caesaldekarin $\mathrm{C}$ isolado do extrato metanólico de raiz de Guilandina bonduc L.

Tabela 6. Dados de RMN de ${ }^{13} \mathrm{C}(300 \mathrm{MHz}, \mathrm{CDCl} 3)^{*}$

\begin{tabular}{rrrr}
\hline $\mathbf{C}$ & $\mathbf{1}$ & $\mathbf{2}$ & $\mathbf{3}$ \\
\hline 1 & 32.4 & 32 & 30.7 \\
2 & 18.7 & 18.7 & 18.4 \\
3 & 32.1 & 31.8 & 31.5 \\
4 & 49.1 & 49 & 48.8 \\
5 & 77.1 & 76.6 & 76.1 \\
6 & 27.9 & 28 & 28.8 \\
7 & 24.8 & 24.6 & 25.4 \\
8 & 34.6 & 35.3 & 40.5 \\
9 & 37.6 & 43.9 & 43.7 \\
10 & 41.7 & 41.8 & 40.8 \\
11 & 22.5 & 22.8 & 37.6 \\
12 & 149.5 & 152.4 & 201.5 \\
13 & 122.3 & 118.7 & 132.4 \\
14 & 31.4 & 142.5 & 160.3 \\
15 & 109.5 & 106.2 & 29.3 \\
16 & 140.3 & 141.4 & 62.3 \\
17 & 17.5 & 103.9 & 17.9 \\
18 & 24 & 23.9 & 23.6 \\
19 & 177.4 & 177.4 & 177.1 \\
20 & 15.1 & 15 & 15 \\
OMe & 51.6 & 51.6 & 51.7 \\
\hline Atribicos
\end{tabular}

* Atribuições foram baseadas em experimentos de carbono de HMQC e HMBC. 


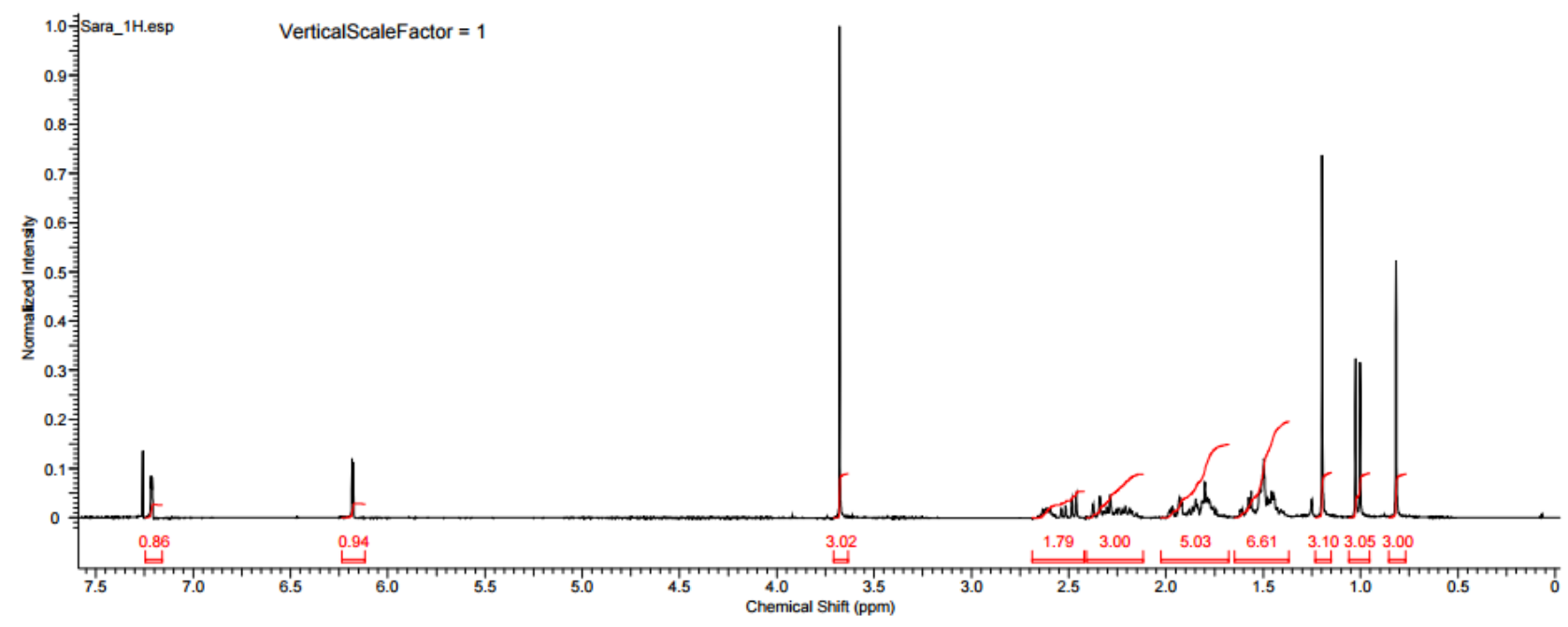

Figura 21. Espectro de $\mathrm{RMN}{ }^{1} \mathrm{H}$ de Caesaldekarin $\mathrm{C}$ isolado do extrato metanólico de raiz de Guilandina bonduc L.

Tabela 7. Dados de $\mathrm{RMN}$ de ${ }^{1} \mathrm{H}\left(300 \mathrm{MHz}, \mathrm{CDCl}_{3}\right)$

\begin{tabular}{|c|c|c|c|}
\hline $\mathrm{H}$ & 1 & 2 & 3 \\
\hline $1 \alpha$ & $1.43(m)^{*}$ & $1.42(\mathrm{~m})$ & $1.35(m)$ \\
\hline $1 \beta$ & $1.52(m)$ & $1.51(m)$ & $1.42(m)$ \\
\hline $2 \alpha$ & $1.48(m)$ & $1.49(m)$ & $1.49(m)$ \\
\hline $2 \beta$ & $1.9(m)$ & $1.91(m)$ & $1.89(m)$ \\
\hline $3 \alpha$ & $1.59(m)$ & $1.58(m)$ & $1.57(m)$ \\
\hline $3 \beta$ & $1.95(m)$ & $1.93(m)$ & $1.95(m)$ \\
\hline $6 \alpha$ & $1.85(m)$ & $\begin{array}{l}1.87(\mathrm{~m}) \\
2.40 \text { (ddd, 14.8, 14.8, }\end{array}$ & $\begin{array}{l}1.86(m) \\
2.49 \text { (ddd, 14.5, 14.5, }\end{array}$ \\
\hline $6 \beta$ & $2.3(m)$ & $5.2)$ & 5.3) \\
\hline $7 \alpha$ & $1.51(m)$ & $1.69(m)$ & $1.47(m)$ \\
\hline $7 \beta$ & $1.8(m)$ & $2.16(m)$ & $2.09(m)$ \\
\hline 8 & $1.79(m)$ & $2.26(m)$ & $2.35(m)$ \\
\hline 9 & $2.20(d d d, 10.7,10.7,7.5)$ & $\begin{array}{l}2.19(d d d, 11.1,11.1 \\
5.6)\end{array}$ & $\begin{array}{l}2.27 \text { (dad, 10.5, 10.5, } \\
\text { 4.0) }\end{array}$ \\
\hline $11 \alpha$ & $2.50(d d, 16.1,7.5)$ & $2.63(d d, 16.7,5.6)$ & $2.38(d d, 15.8,4.0)$ \\
\hline $11 \beta$ & $2.33(d d, 16.1,10.7)$ & $2.45(d d, 16.7,11.1)$ & \\
\hline 14 & $2.62(m)$ & & $2.06(d d, 15.8,10.5)$ \\
\hline \multirow[t]{2}{*}{15} & $6.19(d, 2.5)$ & $6.44(d, 2.1)$ & $2.65(d t, 15.8,6.6)$ \\
\hline & & & $2.55(d t, 15.8,6.6)$ \\
\hline 16 & $7.20(d, 2.5)$ & $7.23(d, 2.1)$ & $3.62(2 \mathrm{H}, \mathrm{t}, 6.6)$ \\
\hline \multirow[t]{2}{*}{17} & $1.02(d, 6.6)$ & $5.09(d, 2.3)$ & $1.95(s)$ \\
\hline & & $4.89(d, 2.3)$ & \\
\hline 18 & $1.20(s)$ & $1.21(s)$ & $1.18(\mathrm{~s})$ \\
\hline 20 & $0.82(s)$ & $0.87(s)$ & $0.82(s)$ \\
\hline OMe & $3.69(s)$ & $3.69(s)$ & $3.69 s)$ \\
\hline
\end{tabular}

*Multiplicidades e constantes de acomplamento (J) em Hz. 
